Adriana Celestino Santiago

\title{
Conexões Aferentes da Área de Transição Amígdalo-Piriforme (APir) no rato
}

Dissertação apresentada ao Instituto de Ciências Biomédicas da Universidade de São Paulo para obtenção do título de Mestre em Ciências

Área de Concentração: Fisiologia Humana Orientadora: Dra. Sara Joyce ShammahLagnado

São Paulo

1999 


\section{AGRADECIMENTOS}

Agradeço a todos que, de um modo singular, contribuíram para a realização deste trabalho:

Aos meus pais ADALBERTO DIAS SANTIAGO e CARMEN SILVIA CELESTINO SANTIAGO,

À minha orientadora Profa. Dra. SARA JOYCE SHAMMAH-LAGNADO,

À amiga LETÍCIA NORMA CARPENTIERI RODRIGUES,

À Profa. Dra. INGE ELLY KIEMLE TRINDADE da FOB de Bauru,

À Profa. Dra. ELZA ARAÚJO TORRES da Universidade do Sagrado Coração de Bauru,

Ao Prof. Dr. DEJAIR CAETANO DO NASCIMENTO da Universidade do Sagrado Coração de Bauru,

Ao Prof. Dr. NEWTON SABINO CANTERAS,

Ao Prof. Dr. JOSÉ CIPOLLA NETO,

Ao Prof. Dr. LUIZ R. G. BRITTO,

À Profa. Dra. DÂNIA EMI HAMASSAKI-BRITTO,

À ANA MARIA PERAÇOLI CAMPOS, técnica do Laboratório de Neuroanatomia,

Às "MENINAS" do Laboratório de Neuroanatomia,

Aos Srs. ROBERTO VIEIRA e ERNESTO RUAS MARQUES, técnicos que prestam assistência aos equipamentos do laboratório,

Ao Sr. ITAMAR KLEMPS, técnico de informática do Depto. de Fisiologia, Às SECRETARIAS DA PÓS-GRADUAÇÃO e DO DEPTO. DE FISIOLOGIA DO ICB,

Às BIBLIOTECÁRIAS DO ICB,

À FUNDAÇÃO DE AMPARO À PESQUISA DO ESTADO DE SÃO PAULO (FAPESP),

E aos que estiveram presentes no agradável convívio da universidade e, mesmo distantes, participaram deste processo. 


\section{RESUMO}

A área de transição amígdalo-piriforme (APir) está situada na encruzilhada dos córtices piriforme, periamigdalóide e entorrinal. As conexões aferentes deste distrito olfativo foram investigadas com técnicas de rastreamento retrógrado, utilizando como traçadores a subunidade $B$ da toxina colérica e o Fluoro-Gold. Nossos experimentos retrógrados mostram que as principais fontes de aferências da APir se originam do bulbo olfativo, de áreas mesocorticais e alocorticais, incluindo os córtices insulares disgranular e agranular posterior, piriforme, entorrinal lateral e perirrinal, o campo temporal CA1 do corno de Ammon e o subiculum ventral, bem como do núcleo endopiriforme dorsal e do complexo amigdalóide (principalmente dos núcleos basomedial anterior, basolateral posterior, cortical anterior, cortical pósterolateral e cortical póstero-medial). Várias outras estruturas, entre as quais o núcleo da banda diagonal de Broca, o pálido ventral, a substância inominada sublenticular, o pólo caudal do núcleo central medial do tálamo, o núcleo reuniens, o núcleo dorsal da rafe, o locus coeruleus e a área parabraquial representam fontes de aferências mais modestas. Nossas observações sugerem ainda que projeções para a APir oriundas de áreas mesocorticais, do complexo amigdalóide e da formação hipocampal são topograficamente organizadas. Injeções de Fluoro-Gold no córtex entorrinal ventrolateral indicam que as conexões aferentes deste território e da APir são diferentes. O padrão das aferências corticais e amigdalianas observado sugere que a APir está envolvida mais particularmente no processamento de informações olfativas, gustativas, viscerais e somestésicas enquanto que o córtex 
entorrinal lateral parece estar mais crucialmente relacionado com 0 processamento de informações visuais e auditivas altamente elaboradas. A APir difere ainda do córtex entorrinal lateral por receber projeções relativamente modestas dos núcleos talâmicos da linha média.

Tomados em conjunto, nossos dados sugerem que, além de constituir uma entidade distinta do córtex entorrinal, a APir parece desempenhar um papel na integração de informações olfativas, gustativas, interoceptivas gerais e somestésicas, transmitindo-as para a amígdala expandida, o striatum ventral e o subiculum ventral, e modulando assim a expressão de comportamentos emocionais e motivados. 


\section{ÍNDICE}

\section{RESUMO}

1.0. INTRODUÇÃO, ....................................................................... 1

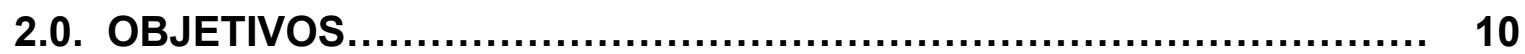

3.0. MATERIAIS E MÉTODOS. ..................................................... 11

3.1. Injeções iontoforéticas dos traçadores................................. 11

3.2. Perfusão e Histologia.................................................. 12

3.3. Imunohistoquímica para a detecção do traçador........................ 13

3.4. Análise e registro dos dados............................................ 14

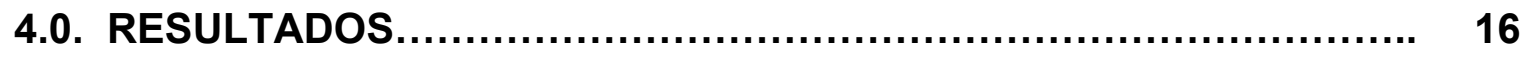

4.1. Considerações metodológicas............................................ 16

4.2. Casos com injeções na APir ........................................... 17

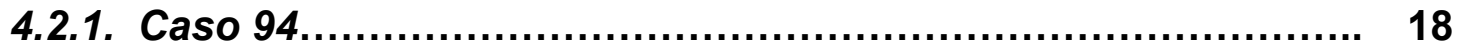

4.2.2. Outros casos com injeção na APir.................................... 21

4.3. Injeções na APir lateral.................................................. 22

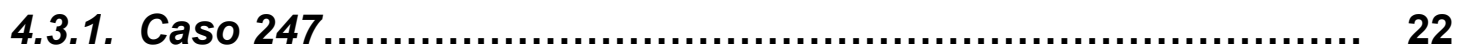

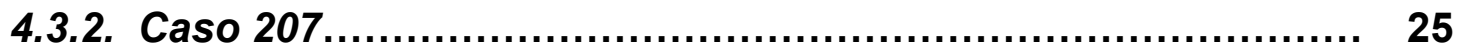

4.4. Injeções na APir medial.................................................. 26

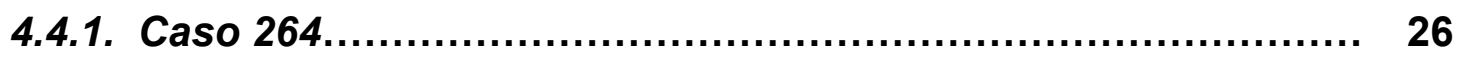

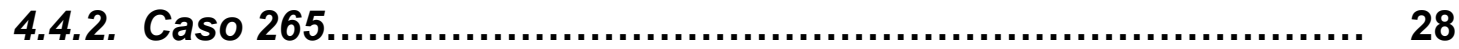

4.5. Injeção na APir Caudal.................................................... 29

4.6. Outros Casos.............................................................. $\quad 30$

4.6.1. Injeção na porção caudal do núcleo amigdalóide basolateral

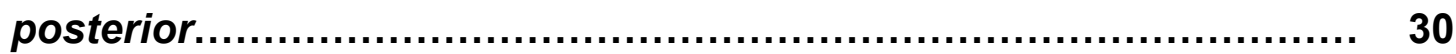

4.7. Casos com injeções no córtex entorrinal lateral...................... $\quad 30$

4.7.1. Injeções no córtex entorrinal dorsolateral e ventrolateral....... 31

4.7.1.1. Caso 114........................................................ 32

4.7.1.2. Caso 119........................................................ 35

4.7.2. Injeções no córtex entorrinal ventromedial......................... 37

4.7.2.1. Caso 115...................................................... 38

4.8. Tabela com os casos representativos............................... $\quad 40$

4.9. Controles anterógrados............................................... 43

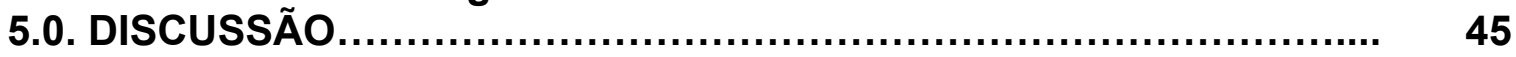

5.1. Considerações Metodológicas.......................................... 45

5.2. Aspectos gerais das aferências da APir.............................. 46

5.3. Organização topográfica das aferências da APir..................... 47

5.4. Principais aferências à APir - comparação com as informações da literatura.................................................................. 48

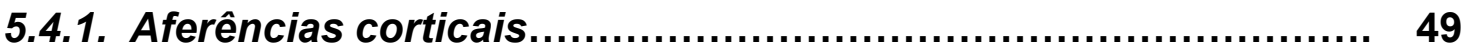

5.4.2. Aferências amigdalianas............................................ 54

5.4.3. Aferências talâmicas.................................................. 56

5.4.4. Aferências do tronco cerebral....................................... 58

5.5. Diferenças em relação aos territórios adjacentes...................... 59 
5.6. Implicações funcionais.................................................. 64

6.0. CONCLUSÓES .............................................................. 70

7.0. REFERÉNCIAS BIBLIOGRÁFICAS, ........................................ 71 LISTA DE ABREVIATURAS

ABSTRACT 


\subsection{INTRODUÇÃO}

A área de transição amígdalo-piriforme (APir) está situada na encruzilhada dos córtices piriforme, periamigdalóide e entorrinal, ocupando o distrito localizado no fundo e no lábio lateral da fissura amigdalóide (Haug, 1976; Paxinos e Watson, 1986; Alheid e cols., 1995). Sua porção rostral é estreita e limitada lateralmente pelo córtex piriforme, medialmente pelo núcleo amigdalóide cortical póstero-lateral e dorsalmente pelo núcleo amigdalóide basolateral posterior. Acompanhando o eixo ântero-posterior da APir, identificamos uma porção intermédia que ocupa um território interposto entre o córtex entorrinal (subdivisão dorsolateral), o núcleo amigdalóide cortical póstero-medial e a área amígdalo-hipocampal. O pólo mais caudal desta área de transição é limitado, e posteriormente substituído, pelas subdivisões ventromedial e ventrolateral do córtex entorrinal lateral (Krettek e Price, 1977).

Do ponto de vista citoarquitetônico, a APir diferencia-se das estruturas vizinhas pela grande espessura de sua camada molecular e pela ausência de

FIGURA 1 um padrão laminar bem definido (Fig. 1). As células do estrato profundo (lâmina III) são maiores do que aquelas observadas no estrato superficial (lâmina II). Em sua porção caudo-lateral as células do estrato superficial formam tipicamente pequenos agregados celulares. A APir não apresenta portanto nenhuma semelhança citoarquitetônica com os córtices piriforme e entorrrinal. Existem diferentes nomenclaturas para designar esta área de transição no rato. Assim, a APir corresponde às áreas e2 e e3 de Popoff e Popoff (1929); à área de transição de Haug (1976); ao pólo mais rostral da 


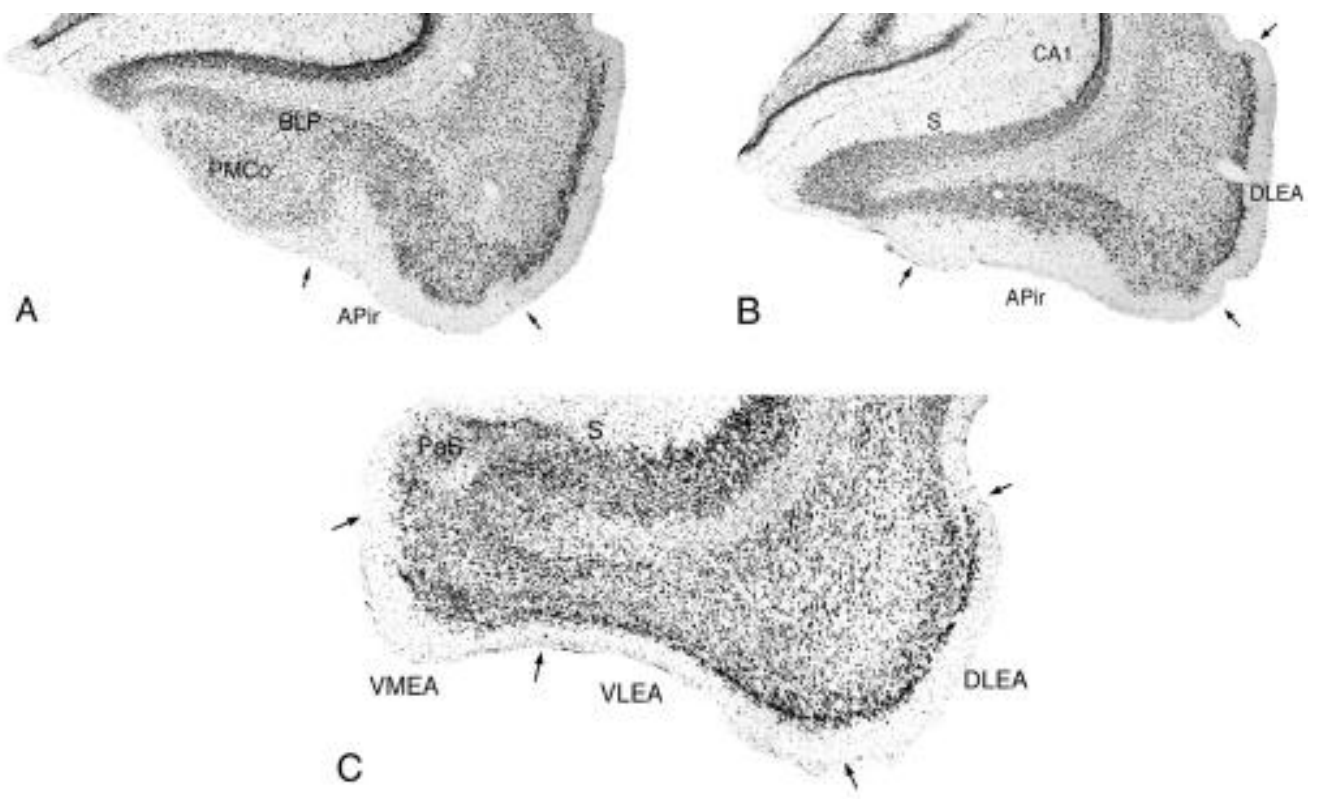

FIGURA 1. Fotomicrografias em campo claro de cortes transversos apresentados em sequência rostro-caudal, ilustrando a citoarquitetura da APir (A e B) e do córtex entorrinal lateral (C). 
área entorrinal lateral ventral de Krettek e Price (1977); à porção sulcal do córtex periamigdalóide (Price e cols., 1987); à zona de transição entre o núcleo basolateral posterior, a área entorrinal lateral ventral e a porção caudolateral do córtex periamigdalóide de Ottersen (1982); à área de transição amígdalo-piriforme de Paxinos e Watson (1986); à área de transição pós piriforme de Swanson (1992); ao campo transicional amígdalo-entorrinal (Insausti e cols., 1997); à transição amígdalaentorrinal de Canning e Leung (1997) e à área entorrinatpiriforme (Korzeniewska e cols., 1997). A APir foi também identificada em primatas, incluindo o homem (Price e cols., 1987; Heimer e cols., 1999).

A APir também se diferencia dos territórios adjacentes do ponto de vista neuroquímico. Em preparações para evidenciar a enzima acetilcolinesterase, a APir apresenta um padrão pontuado de coloração que é muito característico (Alheid e cols., 1995). Em um estudo quimio-arquitetônico da área parahipocampal do rato, Haug (1976) aplicou o método desenvolvido por Timm - que consiste na localização de metais normais e tóxicos em cortes de tecido através da precipitação do sulfeto de prata - e observou que a neurópila das porções anterior e posterior da APir apresentava reatividade diferente para a técnica de Timm. Haug descreve que uma pequena porção caudal desta área de transição exibia uma padrão pontuado de coloração com o sulfeto de prata enquanto que a porção rostral restante se caracterizava por uma reação uniformemente distribuída. Uma diferença de reatividade ao longo da extensão rostro-caudal da APir foi também descrita por Christensen e Geneser (1995) em um estudo histoquímico mais recente que conjugou uma 
modificação da técnica de Timm com o método do selênio permitindo a visualização de neurônios que contém zinco. Esses autores evidenciaram que a densidade de pericários reativos das camadas profundas da APir medial diminuia gradualmente em direção rostro-caudal. Diferenças sugerindo uma organização laminar da APir foram também notadas em um estudo sobre a distribuição da calretinina no córtex entorrinal (Miettinen e cols., 1997). Os autores adotaram uma nomenclatura (Insausti e cols., 1997) que identifica 5 camadas na APir e relataram intensa imunorreatividade na neurópila da camada I, moderada nas camadas $\mathrm{V}$ e $\mathrm{VI}$ e praticamente ausente nas camadas II e III.

A distribuição de neurotransmissores em diversos sítios do sistema nervoso central é amplamente caracterizada na literatura. No entanto, o fato da APir estar localizada na confluência dos córtices periamigdalóide, piriforme e entorrinal torna facultativo aos autores o seu agrupamento dentro de uma destas áreas, o que freqüentemente dificulta a interpretação dos resultados descritos quando estes não são apresentados sob a forma de ilustrações. Em estudos que investigaram a localização de neurotransmissores no cérebro do rato foram identificados na APir plexos de fibras serotoninérgicas (Köhler e cols., 1981) e dopaminérgicas (Fallon e cols., 1978), assim como concentrações moderadas de receptores adrenérgicos (Talley e cols., 1996) e glicinérgicos (Fig. 1K de Fujita e cols., 1991). Esta área de transição apresenta ainda reatividade de alta a moderada para diversos neuropeptídeos como neurotensina (Fig. 5 de Young e Kuhar, 1981), secretoneurina (Fig. 16 de Marksteiner e cols., 1993), ocitocina (Fig. 2 de Yoshimura e cols., 1993), 
neuropeptídeo Y (Fig. 9 de Quidt e Emson, 1986), somatostatina (Fig. 6 de Krantic e cols., 1992), bombesina (Fig. 19 de Woody e cols., 1992), peptídeo relacionado ao gene da calcitonina (Figs 8 e 9 de Skofitsch e Jacobowitz, 1992) e peptídeo vasointestinal (Fig. 24 de Magistretti e cols., 1992).

A APir recebe projeções diretas do bulbo olfativo (Kosel e cols., 1981), o que constitui uma característica hodológica importante pois a tipifica como fazendo parte do sistema olfativo.

Em um estudo autoradiográfico clássico sobre as projeções amigdalianas para o córtex entorrinal, Krettek e Price (1977) subdividiram o córtex entorrinal lateral do rato e do gato em 3 setores (ventromedial, ventrolateral e dorsolateral). Apesar de reconhecerem que a porção rostral e caudal da subdivisão ventrolateral diferiam citoarquitetonicamente, estes autores não consideraram a porção rostral como uma entidade distinta, visto que suas conexões pareciam semelhantes às do córtex entorrinal ventrolateral caudal. Deve ser ressaltado que é bastante difícil obter injeções estritamente confinadas a um determinado núcleo com a técnica autoradiográfica e que a própria delimitação do local de injeção efetivo também é ambígua. Tais limitações sem dúvida contribuíram para obscurecer diferenças hodológicas entre a APir e o córtex entorrinal lateral. Este trabalho faz parte de uma série de estudos clássicos sobre a circuitaria amigdaliana realizados no fim da década de 70 por Price e colaboradores e teve grande repercussão de forma que até hoje a APir é frequentemente considerada como parte integrante do córtex entorrinal (ver por exemplo Beckstead, 1978; Canning e Leung, 1997; Pikkarainen e cols., 1999). Recentemente, Burwell e 
Amaral (1998a) publicaram um estudo de rastreamento retrógrado minucioso no qual eles quantificaram as diferentes fontes de aferências corticais do córtex entorrinal entretanto, nem o setor rostroventral do referido córtex nem a APir foram investigados neste estudo.

A APir é também frequentemente incluída entre os núcleos amigdalóides corticais (de Olmos e cols., 1985; Alheid e cols., 1995); no entanto, a maioria dos estudos anatômicos recentes que investigaram as projeções de vários distritos corticais para a amígdala (Witter e Groenewegen, 1986; Mascagni e cols., 1993; Romanski e LeDoux, 1993; McDonald e cols., 1996; McDonald e Mascagni, 1996; McDonald, 1998; Shi e Cassell, 1998a) e também as conexões intrínsecas da amígdala (Pitkänen e cols., 1995; Savander e cols., 1995, 1996), não incluíram a APir em sua análise. Assim, de um modo geral, existem poucos dados a respeito da circuitaria da APir.

Algumas informações sobre as conexões aferentes da APir podem ser extraídas de observações incidentais de Beckstead (1978) sobre as aferências da área entorrinal estudadas no rato com a técnica da peroxidase do rábano silvestre (HRP). O autor subdivide o córtex entorrinal em uma porção anterior e em dois setores, medial e lateral, localizados mais caudalmente; uma das injeções ilustradas (caso EC14) está centrada na APir. Ao comparar os experimentos obtidos em cada um dos setores, Beckstead observou que o caso com injeção na APir apresentava marcação retrógrada menos proeminente no núcleo reuniens do tálamo, no núcleo lateral da amígdala e no subiculum e, diferentemente dos outros casos, recebia aferências do bulbo olfativo e da área tegmental ventral (ver Tabela 1 de 
Beckstead, 1978). Outro trabalho que traz informações sobre fontes de aferências da APir é o estudo de Pikkarainen e colaboradores (1999) sobre as projeções do complexo amigdalóide basolateral para a formação hipocampal. Os autores utilizam uma nomenclatura (Insausti e cols., 1997) que inclui a APir no córtex entorrinal, denominando-a AE (campo transicional amígdaloentorrinal), e relatam que esta área de transição é densamente aferentada pelo núcleo amigdalóide basolateral posterior, mais modestamente pelo núcleo basomedial e recebe escassas projeções do núcleo lateral.

Além dessas evidências sobre as conexões aferentes da APir, altamente sugestivas de que esta área de transição constitui uma estrutura distinta do córtex entorrinal, várias outras observações sobre suas conexões eferentes revelam diferenças hodológicas entre estes dois territórios. Estudos de rastreamento anterógrado realizados com a técnica da leucoaglutinina do Phaseolus vulgaris (PHA-L) (Shammah-Lagnado e Santiago, 1999) indicam que a APir projeta-se densamente para a formação hipocampal, onde inerva a camada molecular do subiculum ventral e o estrato lacunoso molecular do corno de Ammon, particularmente o campo temporal CA1. Essa área de transição diferencia-se do córtex entorrinal adjacente pelo fato de não se projetar para a camada molecular do giro denteado. Em estudos de rastreamento retrógrado, foi notado que a APir representa uma das principais fontes de aferências do núcleo amigdalóide central enquanto que o córtex entorrinal inerva apenas modestamente o referido núcleo (Ottersen, 1982; Shammah-Lagnado e cols., 1999). A existência de densas projeções da APir para o núcleo amígdalóide central foi também corroborada usando-se o PHA- 
L como traçador anterógrado (Jolkkonen e Pitkänen, 1998; Swanson e Petrovich, 1998; Shammah-Lagnado e Santiago, 1999). Nossas observações anterógradas e de McDonald e colaboradores sugerem ainda que a APir se diferencia do córtex entorrinal por inervar densamente todos os componentes da divisão central da amígdala expandida (McDonald e Mascagni, 1997; McDonald e cols., 1999; Shammah-Lagnado e Santiago, 1999). A divisão central da amígdala expandida é composta pelo núcleo amígdalóide central, pela divisão lateral do núcleo intersticial da estria terminal e pelos distritos que se estendem entre estes dois núcleos (ventralmente, a porção dorsal da região sublenticular e o núcleo intersticial do ramo posterior da comissura anterior e, dorsalmente, os neurônios situados ao longo do trajeto da divisão lateral da estria terminal) (Alheid e cols., 1995). A divisão central da amígdala expandida se projeta para estruturas somáticas e autonômicas situadas no hipotálamo e no tronco cerebral e parece estar crucialmente implicada na expressão de emoções e de comportamentos motivados (ver Heimer e cols., 1993, 1997).

Tomados em conjunto, estes dados sugerem que a APir constitui uma entidade distinta do córtex entorrinal, em particular pelo fato de representar uma importante via de acesso à divisão central da amígdala expandida. Essa noção é reforçada por observações obtidas com transporte transneuronal retrógrado de pseudovírus da raiva (PRV). Assim, pericários infectados transneuronalmente foram notados na APir e na amígdala expandida após injeção de PRV no gânglio parassimpático ptérigo-palatino (Spencer e cols., 1990). A APir parece fazer parte também do conjunto de estruturas 
prosencefálicas que regulam a saída do sistema nervoso simpático (A.D. Lowey, comunicação pessoal). Neste contexto, é interessante mencionar que, no rato, ocorre expressão de proteína fos na APir e na circuitaria vinculada à APir durante o comportamento predatório (Comoli, 1997).

Evidências eletrofisiológicas indicam que a estimulação elétrica da APir evoca intensa ativação da camada molecular externa do giro denteado. Este efeito seria possivelmente mediado por projeções da APir para a camada Il do córtex entorrinal (Canning e Leung, 1997). Assim, informações processadas na APir, além de serem veiculadas para estruturas somáticas e autonômicas do hipotálamo e tronco cerebral, também poderiam potencialmente ativar a circuitaria trissináptica hipocampal permitindo a consolidação de um evento biologicamente relevante.

Regiões límbicas apresentam baixo limiar epileptógeno. Em experimentos nos quais o estado epiléptico foi induzido por estimulação elétrica do núcleo amigdalóide basolateral e as estruturas ativas foram mapeadas com a técnica autoradiográfica da 2-deoxiglucose (2-DG), observou-se inicialmente a ativação dos núcleos amigdalóides basolateral e central, do núcleo intersticial da estria terminal e da APir. Esse conjunto de estruturas estaria assim crucialmente implicado na propagação de descargas anômalas para outros territórios límbicos e, a partir daí, para extensas regiões cerebrais (Handforth e Ackermann, 1988, 1995). O esclarecimento desta circuitaria poderia implicar em maior compreensão do espraiamento de descargas epilépticas e talvez possibilitar alguma ação terapêutica (Kikvadze e Foster, 1995). 
Considerando que o conhecimento das aferências da APir é ainda bastante fragmentado e que a elucidação desta circuitaria é de grande relevância para uma melhor compreensão de importantes processos fisiológicos, resolvemos investigar de forma sistemática as conexões aferentes da APir, usando como traçadores retrógrados a subunidade b da toxina colérica $(\mathrm{CTb})$ e o Fluoro-Gold (FG). Visando comparar o quadro das aferências da APir e do córtex entorrinal lateral, injeções de FG foram também realizadas neste território. 


\subsection{OBJETIVOS}

Analisar as conexões aferentes da APir no rato, utilizando como traçadores retrógrados a CTb e o FG, e comparar as conexões deste território com as do córtex entorrinal lateral adjacente. Para os experimentos de controle, utilizamos PHA-L como traçador anterógrado. 


\subsection{MATERIAIS E MÉTODOS}

Em nossos experimentos foram utilizadas 91 ratas albinas, adultas, da cepa Wistar pesando de 170 a 210 g. Todos os procedimentos cirúrgicos foram feitos sob anestesia com Equitesin (3.3 ml/kg, i.p.).

\subsection{Injeções iontoforéticas dos traçadores}

Injeções estereotáxicas unilaterais de CTb (low salt, List Biological Labs) a 1\% em água destilada ou de uma solução de FG (Fluorochrome, Inc.) a $2 \%$ em salina foram feitas na APir $(n=45)$ ou no córtex entorrinal lateral $(n=26)$. Para os controles anterógrados, foi injetada uma solução de PHA-L (Vector Laboratories, Inc.) a 2,5\% em tampão fosfato de sódio (NaPBS ) 0,1 $M$, tendo como alvos os núcleos amigdalóides lateral $(L a)(n=12)$ e basolateral posterior (BLP) $(n=8)$. Os 3 traçadores foram ejetados iontoforeticamente através de micropipetas de vidro (com diâmetro interno de ponta em torno de 15 a $20 \mu \mathrm{m}$ nos casos de FG e CTb, e de 12 a $15 \mu \mathrm{m}$ nos experimentos com PHA-L) . Por meio de uma fonte de corrente constante (Midgard Electronics, modelo CS 3) passou-se uma corrente positiva, com pulsos de 7 segundos de duração, de 1,5 a 2,5 $\mu \mathrm{A}$ por 20 a 30 minutos pela solução de CTb, de 1,5 a $5 \mu \mathrm{A}$ por 4,5 a 10 minutos pela solução de $\mathrm{FG}$ e de $5 \mu \mathrm{A}$ por 20 minutos pela solução de PHA-L. Após o término da injeção, a micropipeta permaneceu no local por mais 30 minutos para evitar a formação de rastro ao longo do trajeto da pipeta. Esta precaução se revelou necessária particularmente nos casos com depósito de CTb. 


\subsection{Perfusão e Histologia}

Após um tempo de sobrevida, 5 a 8 dias nos casos com injeções de CTb e FG, e 12 a 15 dias para aqueles que receberam um depósito de PHA$\mathrm{L}$, os animais foram anestesiados e perfundidos intracardiacamente utilizando-se uma bomba peristáltica (Cole Parmer) com $100 \mathrm{ml}$ de uma solução de salina a $0,9 \%$ seguida de $500 \mathrm{ml}$ de uma solução a $4 \%$ de paraformaldeído dissolvido em tampão fosfato de sódio a $0,1 \mathrm{M}$ a $\mathrm{pH} 7,4$. Depois de 1 hora os cérebros foram removidos, colocados na mesma solução fixadora utilizada para a perfusão e mantidos a $4^{\circ} \mathrm{C}$. Após 4 horas de imersão foram transferidos para uma solução contendo $20 \%$ de sacarose em tampão fosfato $0,1 \mathrm{M}$ a pH 7,4 onde permaneceram por aproximadamente 12 horas a $4^{\circ} \mathrm{C}$. A seguir os cérebros foram cortados em micrótomo de congelação em plano frontal. Foram colhidos cortes seriados de $40 \mu \mathrm{m}$ de espessura, distribuídos em 5 compartimentos: 4 deles contendo uma solução anticongelante (para processamento imunohistoquímico) e um contendo uma solução de azida de sódio a 0,02\% em tampão fosfato de potássio (KPBS) a 0,02 M (para visualização da citoarquitetura pelo método da tionina). Geralmente 2 séries completas foram processadas na imunohistoquimicamente para CTb, FG ou PHA-L, usando-se a técnica da peroxidase-avidina biotina. 


\subsection{Imunohistoquímica para a detecção do traçador}

Os cortes de cada compartimento foram inicialmente incubados a $4^{\circ} \mathrm{C}$ numa solução contendo o anticorpo primário durante 24 a 72 horas. Após várias lavagens com KPBS $0,02 \mathrm{M}$, os cortes foram transferidos para a solução contendo o anticorpo secundário onde permaneceram por 2 horas, à temperatura ambiente.

Para os casos com injeções de CTb, os cortes foram incubados numa solução de KPBS 0,02 M contendo um anticorpo primário obtido em cabra (List Biological Labs) numa diluição 1:10.000, Triton-X a 0,3\% e soro normal de burro a $2 \%$. A segunda incubação foi com uma solução contendo um anticorpo secundário biotinilado anticabra feito em burro (Jackson) diluído 1:4.000 em KPBS 0,02 M e Triton X-100 a 0,3\%.

Nos casos com injeção de FG, a solução da primeira incubação continha o anticorpo primário feito em coelho (Chemicon International) diluído 1:5.000 numa solução de KPBS $0,02 \mathrm{M}, 0,3 \%$ de Triton X-100 e 10\% de lactoproteína (leite em pó desnatado). Na segunda incubação, os cortes foram transferidos para uma solução contendo o anticorpo secundário biotinilado anticoelho feito em cabra (Vector Laboratories, Inc.) diluído 1:200 em KPBS 0,02 M e Triton X-100 a 0,3\%.

Os cortes dos casos com injeção de PHA-L foram incubados em uma solução de KPBS 0,02 M contendo Triton X-100 a 0,3\%, soro normal de cabra a $2 \%$ e o anticorpo primário obtido em coelho (Dako) numa diluição de 1:5.000. O procedimento para a segunda incubação foi o mesmo do FG.

Após a incubação com o secundário, os cortes de cada 
compartimento (CTb, FG e PHA-L) foram submetidos a várias lavagens com KPBS 0,02 M e expostos ao complexo peroxidase avidina-biotina (Vectastain, kit Elite ABC, Vector) diluído 1:200 em KPBS 0,02 M contendo 0,3\% de Triton $\mathrm{X}-100$, a temperatura ambiente, por 2 horas. Após muitas lavagens com KPBS 0,02 M, foi aplicada a diaminobenzidina (DAB) como cromógeno, posteriormente revelada usando-se o procedimento da glucose oxidase descrito por Itoh e cols. (1979).

Após a reação imunohistoquímica, os cortes foram montados em lâminas recobertas com gelatina alumen-cromo e mergulhados numa solução aquosa de tetróxido de ósmio por 15 a 30 segundos para intensificar a visualização da marcação retrógrada. O material histológico foi desidratado, diafanizado em xilol e recoberto com DPX. Uma série adjacente foi corada com tionina.

\subsection{Análise e registro dos dados}

Os cortes foram analisados em microscópio óptico de campo claro e campo escuro. Os locais de injeção e a marcação (retrógrada e anterógrada) foram mapeados usando-se um sistema onde a câmera lúcida é posicionada frente a um monitor que se conecta a um microcomputador, através do qual os desenhos semi-esquematizados foram elaborados e editados usando-se o programa AutoCAD Release 13. O parcelamento citoarquitetônico e a nomenclatura aplicados às figuras se basearam, de um modo geral, no atlas de cérebro de rato de Paxinos e Watson (1997). Para melhor identificação das diferentes camadas do córtex entorrinal, utilizamos o atlas de cérebro de 
rato de Swanson (1992). A nomenclatura das áreas mesocorticais segue o parcelamento adotado por McDonald (1998). O córtex entorrinal foi parcelado como originalmente proposto por Krettek e Price (1977) em córtex entorrinal medial e lateral, e este último subdividido em 3 áreas: dorsolateral, ventrolateral (incluindo a APir) e ventromedial. 


\subsection{RESULTADOS}

\subsection{Considerações metodológicas}

A aplicação de 2 traçadores retrógrados (CTb e FG) mostrou-se bastante vantajosa nesse estudo.

Nos casos com injeções de CTb, foram obtidos depósitos pequenos que acometeram diferentes setores e camadas da APir, e também algumas injeções restritas ao núcleo basolateral posterior da amígdala e ao córtex entorrinal ventrolateral; que limitam, respectivamente, as porções rostral e caudal da APir.

Objetivando atingir a APir em sua totalidade (camadas profundas e superficiais) decidimos empregar também o FG. Variando-se os parâmetros de injeção iontoforética, obtivemos depósitos de traçador que envolveram praticamente toda a extensão da APir e outros menores que acometeram apenas um determinado setor do território alvo. A fim de podermos comparar as conexões da APir com as do córtex entorrinal adjacente, realizamos também injeções nas porções rostrais das subdivisões dorsolateral, ventrolateral e ventromedial do córtex entorrinal lateral (ver parcelamento citoarquitetônico de Krettek e Price, 1977).

O quadro geral das aferências da APir se revelou o mesmo com a utilização de FG ou CTb. Entretanto, de um modo geral, um número maior de neurônios retrogradamente marcados foi observado nos casos com injeção de FG. Desse modo, projeções que se revelaram modestas com injeções de 
CTb, como aquelas oriundas do tálamo da linha média, puderam ser melhor observadas e valorizadas com o uso de FG. Notamos ainda que a marcação retrógrada em um pequeno grupamento de células na camada Ilb da divisão póstero-dorsal do núcleo amigdalóide medial só pôde ser identificada nos casos com injeção de FG. Essa marcação é, caracteristicamente, pouco intensa. Apesar de não ser o objetivo desse trabalho comparar esses dois traçadores, nossas observações sugerem que, nas condições experimentais utilizadas, o FG é mais sensível que a CTb.

\subsection{Casos com injeções na APir}

Em 13 animais (casos 60, 63, 64, 65, 73, 86 e 89 com depósito de

mostrou praticamente confinada à APir (Figs 2 e 3). A injeção envolveu o setor rostral (caso 60), medial (casos 63, 64, 65, 264 e 265), lateral (caso 86, 207 e 247) ou caudal (caso 89) da APir. Algumas diferenças foram notadas entre estes casos, em particular 1) entre os casos com injeção restrita às camadas profundas da APir e aqueles que envolveram também a lâmina I e 2) entre os casos com injeções localizadas nas porções medial e lateral da APir. Estas diferenças serão comentadas a seguir.

O caso 94 possui uma injeção de FG que abarca praticamente toda a extensão da APir sendo, por esse motivo, escolhido como caso representativo para descrever o quadro geral das aferências desta área (ver Tabela 1). Nos casos 247 e 264, os depósitos de FG são pequenos, estão restritos aos setores lateral e medial da APir, respectivamente, e encontram- 


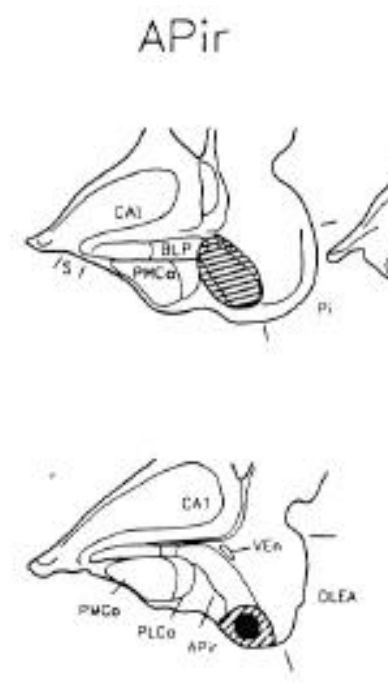

207

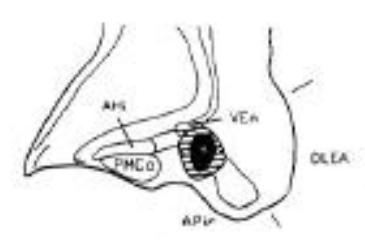

63

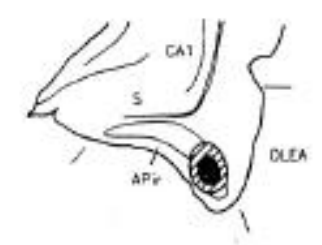

247

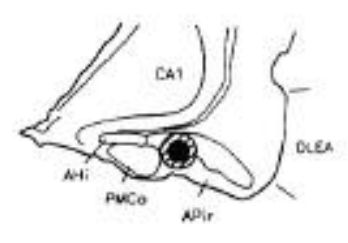

264

\section{LEA}

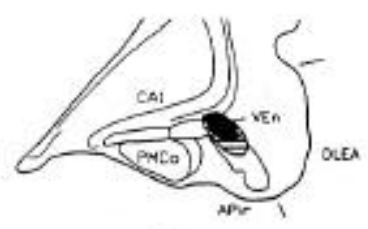

65

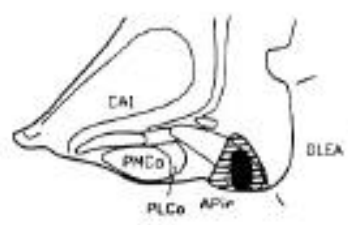

86

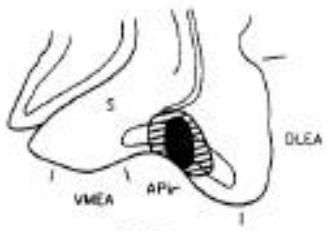

89
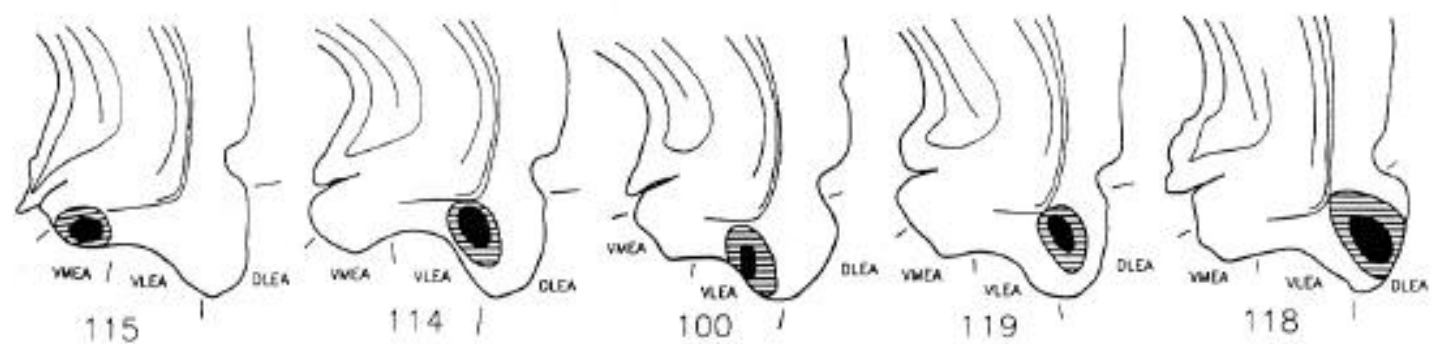

FIGURA 2. llustração dos locais de injeção em 13 casos que são representativos dos diferentes distritos da APir e do córtex entorrinal lateral, explorados no presente trabalho. A área preta representa o centro do local de injeção e a área hachurada denota a região com depósito de traçador menos denso. Caso 94: depósito de FG que abrange praticamente toda a extensão da APir; casos 207 e 247: depósitos de FG na porção lateral da APir; caso 264: depósito de FG na porção medial da APir; caso 63: depósito de CTb na porção medial da APir; caso 65: depósito de CTb nas lâminas profundas da porção medial da APir; caso 86: depósito de CTb na porção lateral da APir; caso 89: depósito de CTb na porção caudal da APir; caso 115: depósito de FG no córtex entorrinal ventromedial; casos 100 e 114: depósito de FG situado nas camadas profundas (114) e superficiais (100) do córtex entorrinal ventrolateral; casos 118 e 119: depósito de FG centrado nas camadas profundas (119) e superficiais (118) do córtex entorrinal dorsolateral. 

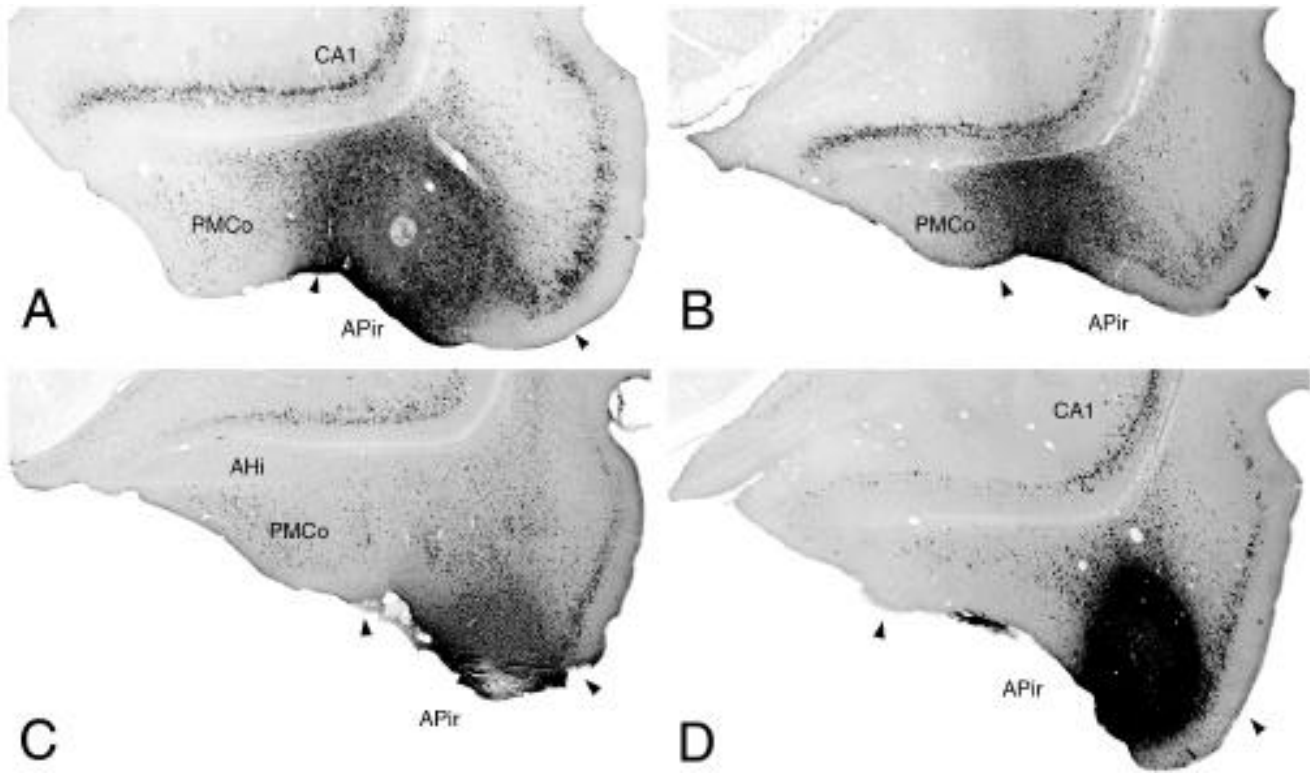

FIGURA 3. Fotomicrografias em campo claro ilustrando depósitos de FG nos casos APir 94 (A), APir medial 264 (B) e APir laterais 207 (C) e 247 (D). 
se em níveis bastante próximos no que se refere ao eixo ântero-posterior. Estes casos serão descritos para ilustrar as diferenças topográficas das aferências da APir, observadas ao longo da sua extensão médio-lateral. No caso 89, obtivemos um depósito de CTb confinado à porção mais caudal da APir. Esse caso difere em vários aspectos dos demais casos da série, o que sugere a existência de um território de transição entre a APir e o córtex entorrinal ventrolateral.

\subsubsection{Caso 94}

O depósito de FG nesse caso atinge praticamente toda a extensão da APir acometendo também perifericamente um pequeno grupamento celular situado dorsolateralmente à APir referido como núcleo endopiriforme ventral no atlas de Swanson (1992). O local de injeção envolve as camadas

FIGURA 2 FIGURA 3 superficiais e profundas e o centro do depósito se localiza em um setor intermédio da extensão rostro-caudal (Fig. 2 e 3A).

As fontes de aferências da APir se originam principalmente de estruturas telencefálicas e são quase exclusivamente ipsolaterais.

No córtex cerebral, a marcação retrógrada está restrita a áreas mesoe alocorticais. Uma densa marcação retrógrada foi observada na área insular, em suas divisões disgranular e agranular posterior (principalmente nas lâminas II e III; Fig. 4C-G), nos córtices piriforme (Fig. 4B-L), entorrinal lateral (principalmente nas lâminas llb e V, mas também na lâmina VI), perirrinal (na região do fundo e do lábio ventral da fissura rinal) (Fig. 4L-O), no campo temporal CA1 do corno de Ammon (mais particularmente no estrato piramidal superficial) e no subiculum ventral, sobretudo em sua porção mais caudal 


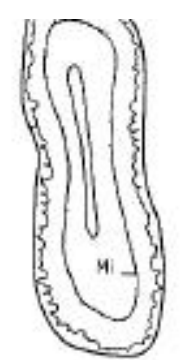

A
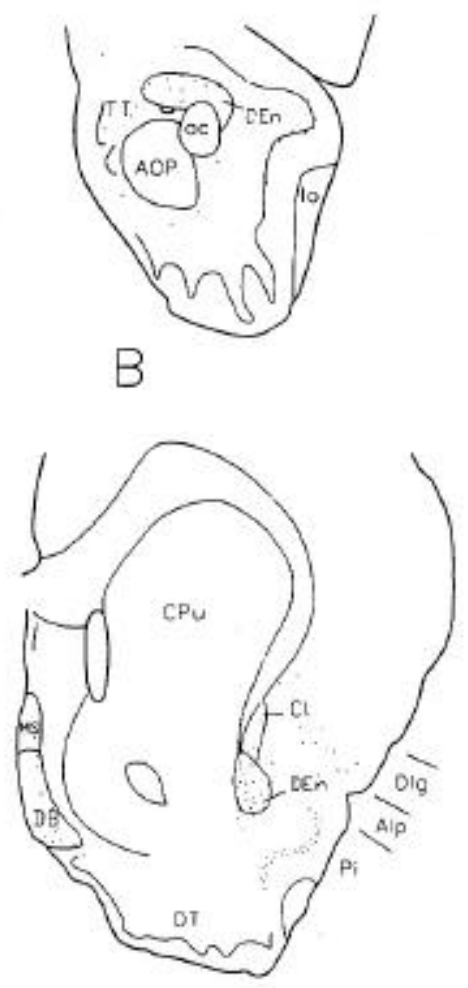

C

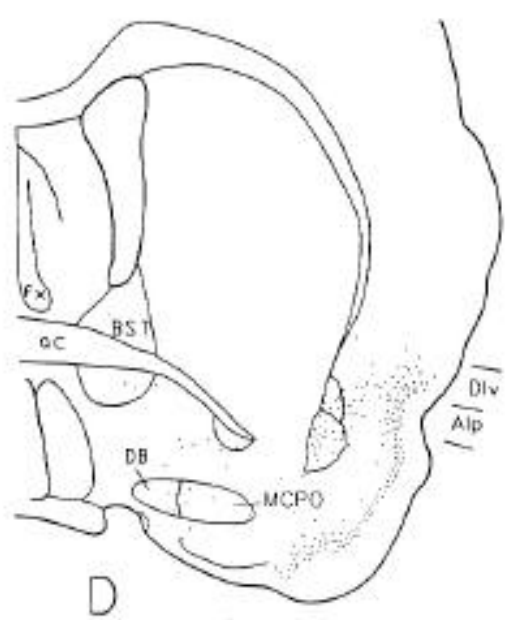

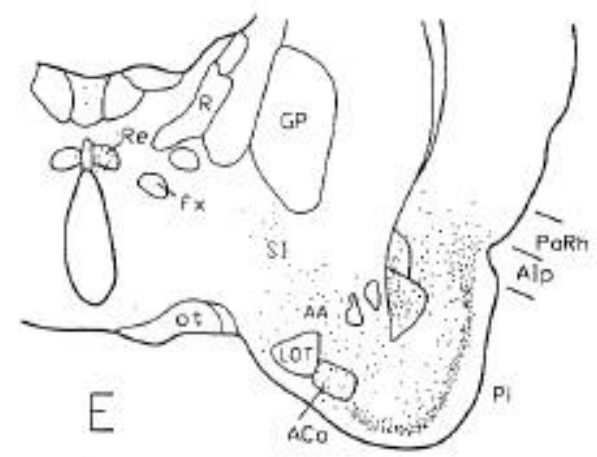
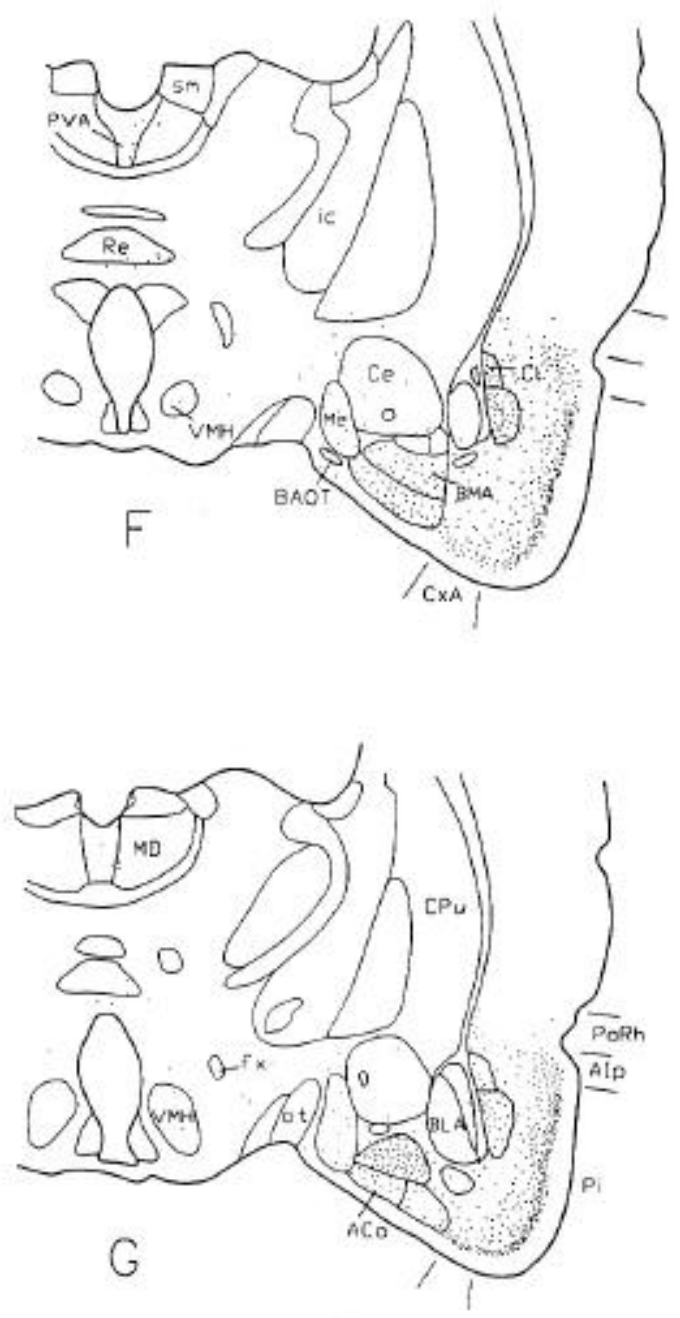

FIGURA 4. Representação semi-esquemática de cortes frontais apresentados em sequência rostro-caudal mostrando a distribuição dos neurônios retrogradamente marcados no caso 94, representativo dos experimentos com depósito de FG na APir. Em ( $\mathrm{K}$ e $\mathrm{L}$ ) a área preta representa o centro do local de injeção e a área hachurada denota a região com depósito de traçador menos denso. Uma fotomicrografia deste local de injeção é mostrado na figura 3 A 

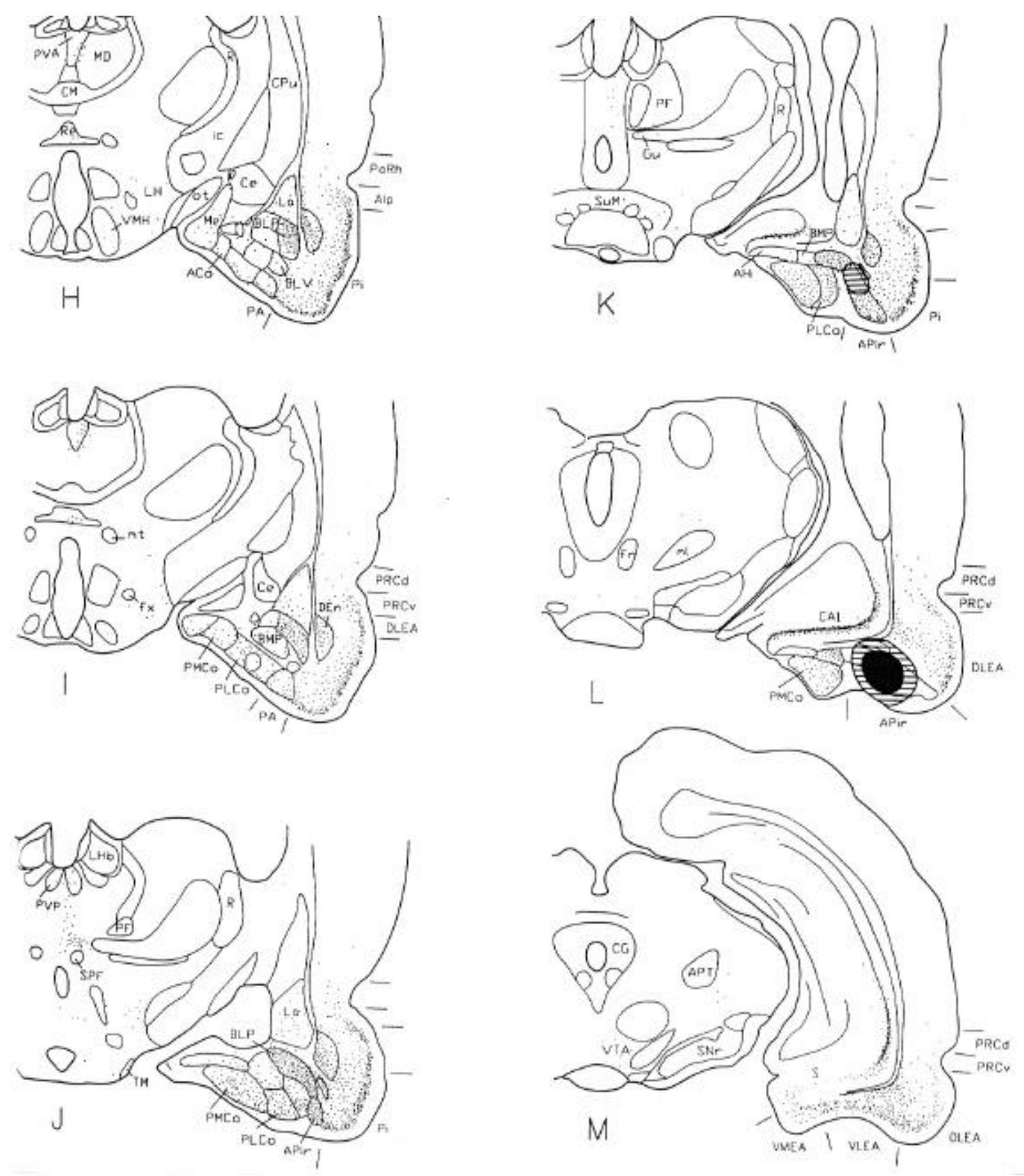

CONTINUAÇÃO DA FIGURA 4. 


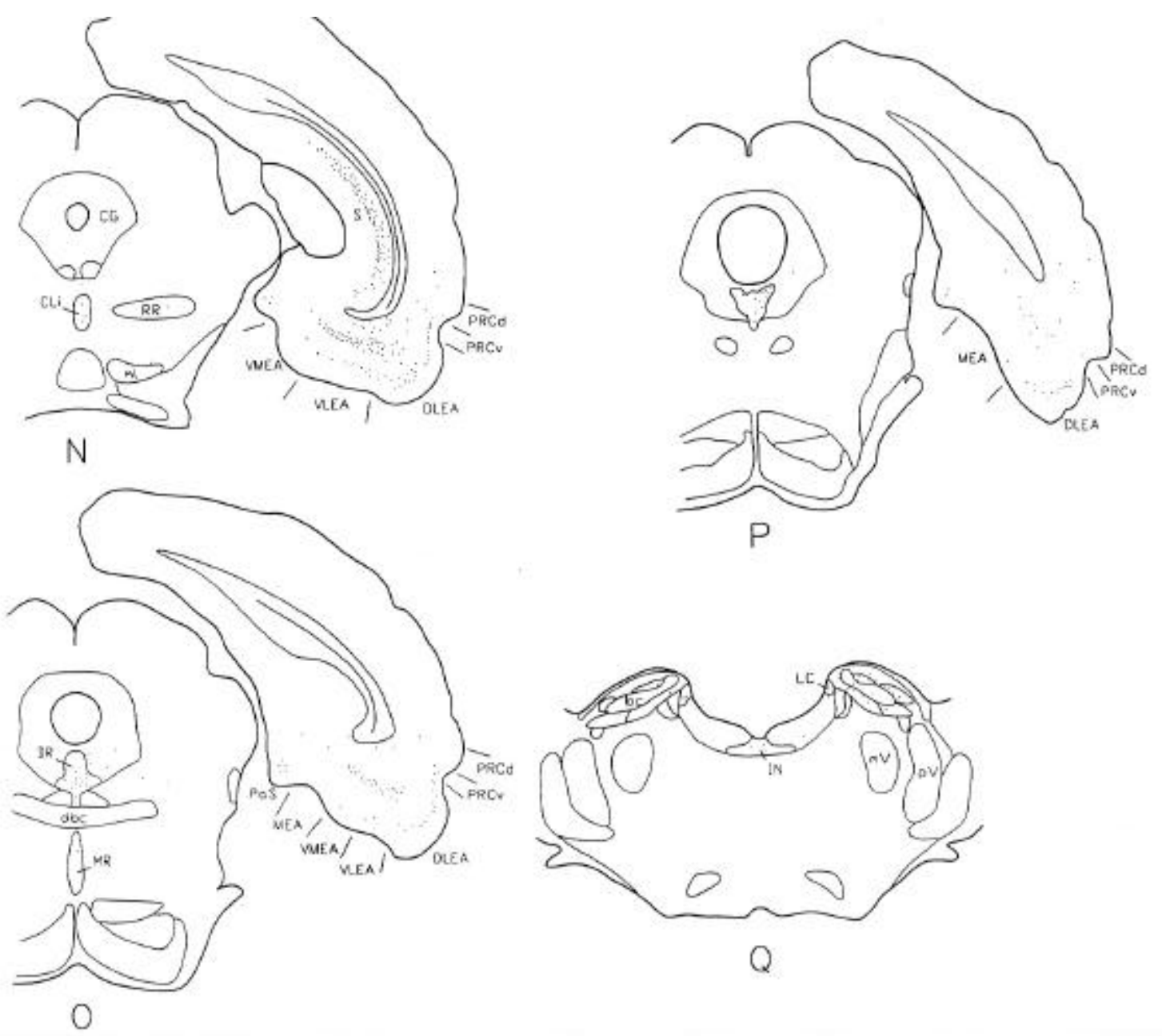

CONTINUAÇÃO DA FIGURA 4. 
(Fig. 4K-N). No córtex piriforme, a marcação retrógrada é muito mais numerosa caudal do que rostralmente; em sua porção rostral é bilateralmente distribuída, e em sua porção caudal é ipsolateral. No córtex entorrinal lateral, a marcação retrógrada é mais abundante em suas divisões ventrolateral e ventromedial e diminui gradativamente em direção caudal. Um grande número de neurônios marcados foi encontrado no núcleo endopiriforme dorsal; sua distribuição não é homogênea, sendo estes mais numerosos no distrito adjacente à capsula externa, quadro que sugere uma organização laminar incipiente deste núcleo (Fig. 4B-K). O claustrum e a divisão ventral do núcleo endopiriforme estão mais modestamente marcado (Fig. 4C-G). Pericários retrogradamente marcados foram ainda notados na camada de células mitrais do bulbo olfativo (Fig. 4A) e, em bem menor número, na tenia tecta, nos setores dorsomedial e posterior do núcleo olfativo anterior (Fig. 4AB), nas divisões dorsal e ventral do córtex insular agranular, no campo septal CA1, no subiculum dorsal e no parasubiculum (Fig. 4M-P).

A amígdala constitui outra importante fonte de aferências FIGURA 5 telencefálicas da APir (Fig. 5A). Os núcleos basomedial anterior (Fig. 4F-H) e basolateral posterior (Fig. 4H-K, 5A) são os que exibem maior densidade de células retrogradamente marcadas. É interessante notar que a marcação no núcleo basolateral posterior continua-se sem transição aparente com a marcação que recobre a porção rostral da APir (Fig. 4J). Os núcleos amigdalóide cortical anterior, cortical póstero-lateral e cortical póstero-medial também apresentam uma marcação retrógrada muito substancial (Fig. 4E-L). Um número mais modesto de células retrogradamente marcadas foi visto na 


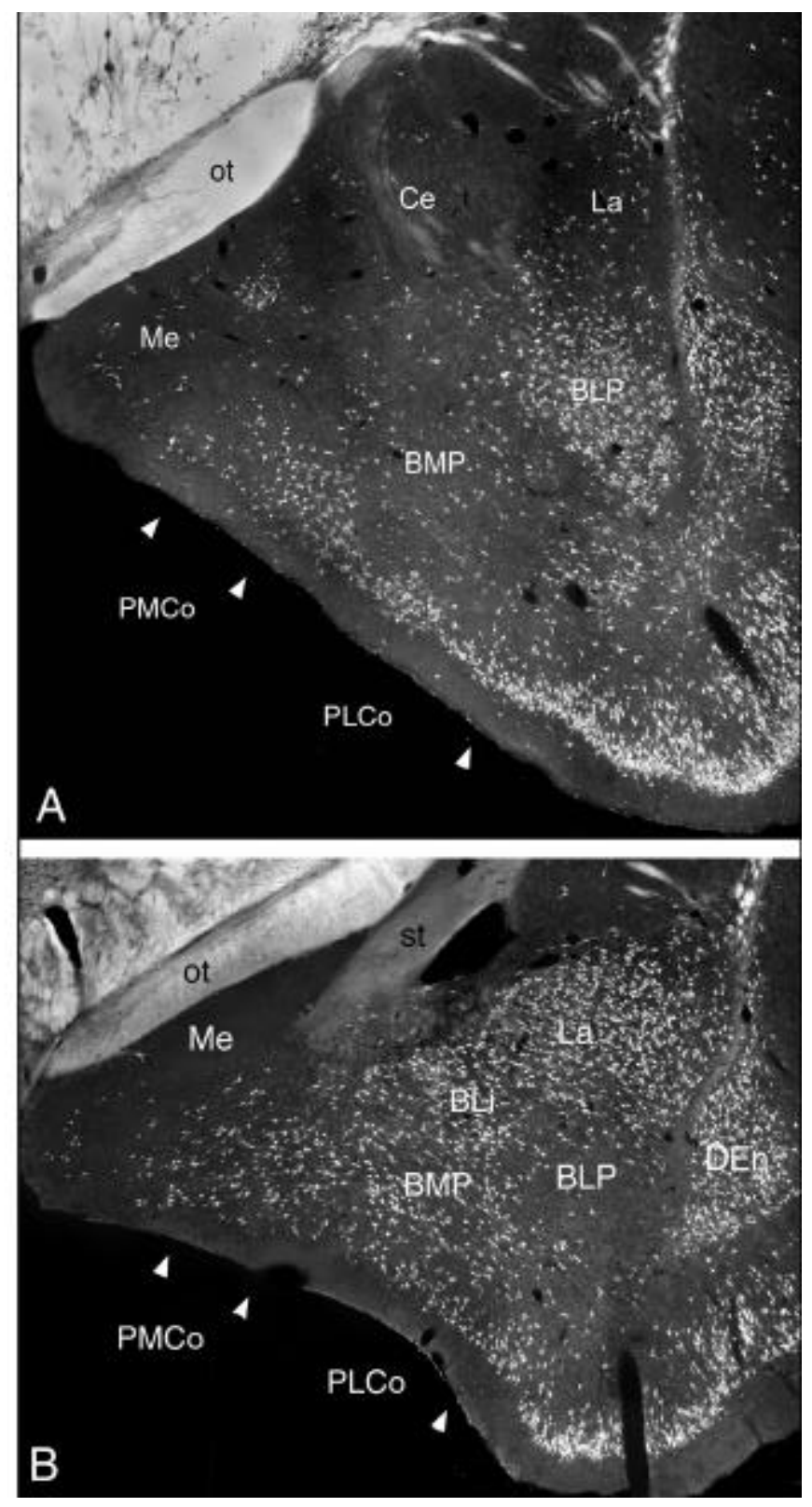

FIGURA 5. Fotomicrografias em campo escuro ilustrando a distribuição da marcação retrógrada na amígdala após injeção de FG na APir (caso 94, em A) e no córtex entorrinal ventrolateral (caso 114, em B). 
área amigdalóide anterior, na área amígdalo-piriforme de Swanson (1992), nos núcleos amigdalóides medial, basolateral ventral, basomedial posterior e

FIGURA 4 lateral, assim como na área amígdalo-hipocampal (Fig. 4E-L). No núcleo amigdalóide medial, a marcação retrógrada está distribuída nas divisões ântero-dorsal, ântero-ventral, póstero-ventral. A divisão póstero-dorsal deste núcleo, com a exceção de um pequeno aglomerado de células tenuamente FIGURA 5 marcadas na lâmina IIb, está praticamente desprovida de marcação (Fig. 5A). Esse aglomerado parece corresponder ao grupo compacto de células calbindina-negativas obervado no rato por McDonald (1997). No núcleo amigdalóide lateral, neurônios retrogradamente marcados foram encontrados na divisão ventromedial, e em menor número nas divisões dorsolateral e ventrolateral. Escassos pericários marcados foram detectados ainda nos núcleos amigdalóides central e basolateral anterior, assim como no núcleo intersticial da estria terminal (Fig. 4D-I).

Uma marcação retrógrada de densidade moderada foi vista ao longo do continuum prosencefálico representado pelo núcleo da banda diagonal de Broca, pálido ventral e substância inominada sublenticular. Poucos pericários marcados foram observados na área septal medial e no núcleo pré-óptico magnocelular (Fig 4C-E).

No hipotálamo, uma marcação retrógrada modesta foi observada nos núcleos ventromedial, túbero-mamilar, hipotalâmico posterior e supramamilar lateral e na área hipotalâmica lateral, principalmente em seu setor pósterolateral (Fig. 4F-K).

No tálamo, a marcação retrógrada é de densidade moderada e está 
concentrada em núcleos da linha média. Os dois principais focos de marcação estão localizados na porção rostral do reuniens e em um setor situado dorsalmente ao núcleo subparafascicular magnocelular, em um território que, de acordo com o atlas de Swanson (1992), parece

FIGURA 4 corresponder à porção mais caudal do núcleo central medial (Figs. 4J, 6B). FIGURA 6 Neurônios retrogradamente marcados foram também observados nos núcleos paraventricular anterior e posterior, intermédio dorsal e, em bem menor número, no núcleo paratenial, na divisão medial do núcleo médio-dorsal do tálamo, na porção parvicelular do núcleo ventropóstero-medial, que corresponde ao relé talâmico gustativo, na região ventromedial do núcleo parafascicular e no complexo posterior do tálamo (Fig. 4E-M).

No tronco cerebral, os núcleos dorsal da rafe (Fig. 4O-P) e locus coeruleus, e a área parabraquial (Figs. 4Q, 6C) possuem um número apreciável de neurônios retrogradamente marcados. $\mathrm{Na}$ área parabraquial a marcação está localizada nos subnúcleos medial e ventral lateral, na divisão interna do subnúcleo externo lateral e na "área da cintura" (waist area). Uma modesta marcação retrógrada foi também observada contralateralmente na área parabraquial e no locus coeruleus. Neurônios retrogradamente marcados foram ainda notados na área tegmental ventral, no campo retrorrubral, na substância cinzenta periventricular e nos núcleos linear caudal e mediano da rafe, e incerto (Fig. 4M-Q).

\subsubsection{Outros casos com injeção na APir}

Com exceção da marcação observada no subnúcleo externo-lateral da área parabraquial, a distribuição da marcação retrógrada no caso 94 foi 

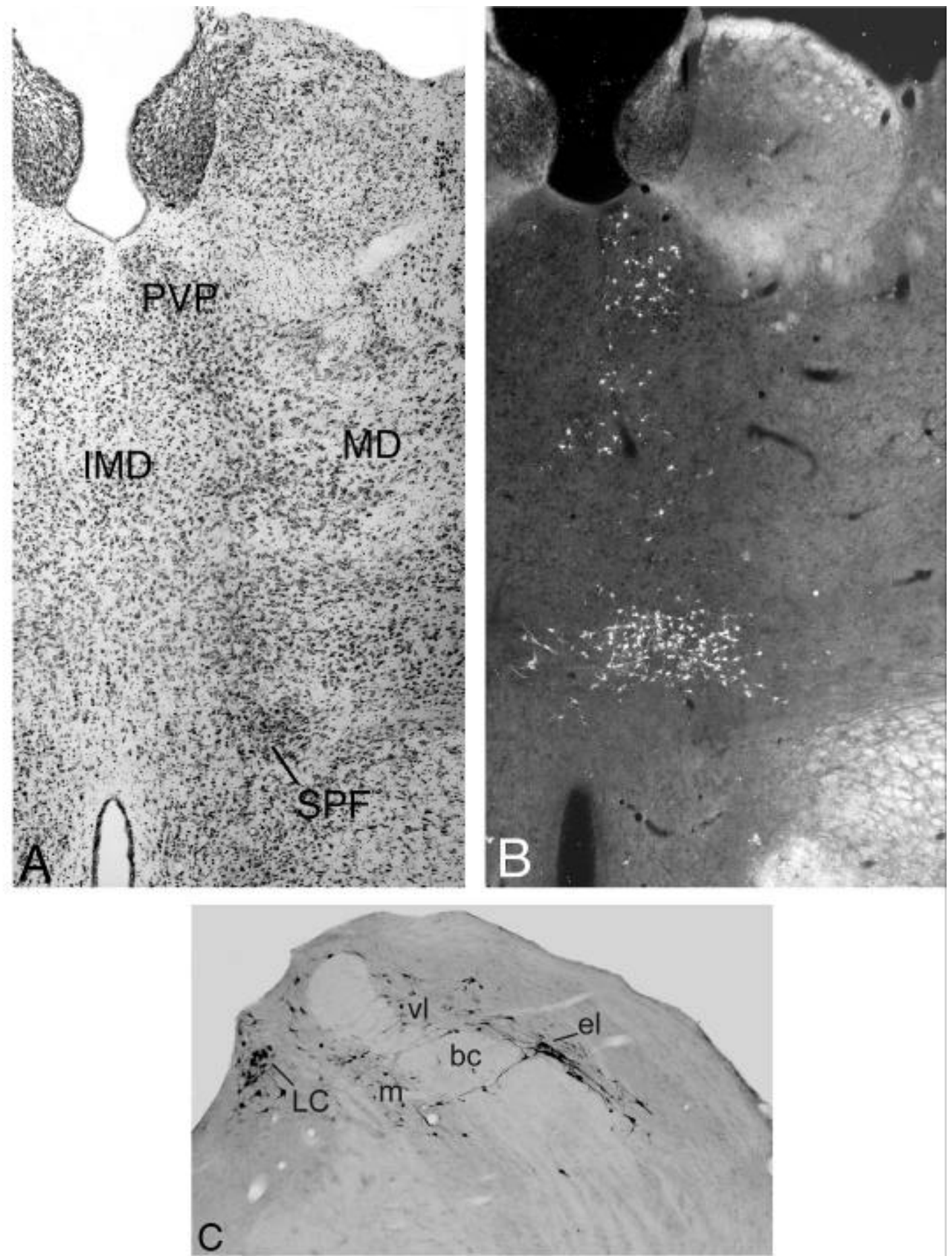

FIGURA 6. Fotomicrografia em campo escuro ilustrando a distribuição da marcação retrógrada no tálamo no caso APir 94 (B). Notar o foco de neurônios retrogradamente marcados dorsalmente à divisãc magnocelular do núcleo subparafascicular. Fotomicrografia em campo claro do corte adjacente ilustrando a citoarquitetura deste território talâmico (A). Fotomicrografia em campo claro ilustrando a distribuição da marcação retrógrada na área parabraquial deste mesmo caso (C). 
confirmada em outros casos com injeções na APir. Em casos que invadiram mais apreciavelmente distritos situados rostromedialmente à APir, em particular a extensão caudal do núcleo amigdalóide basolateral posterior (como por exemplo no caso 85), o subnúcleo externo-lateral encontra-se conspicuamente marcado, de modo que é provável que uma contaminação periférica de distritos adjacentes à APir tenha constribuído no caso 94 para a marcação parabraquial mais extensa.

\subsection{Injeções na APir lateral}

As injeções de FG confinadas aos distritos laterais da APir (casos 207

FIGURA 7 e 247) apresentaram um quadro de aferências (Fig. 7) bastante semelhante àquele observado no caso 94 (no qual o depósito de traçador envolve praticamente toda a extensão da APir).

\subsubsection{Caso 247}

Neste caso, o depósito de FG é relativamente pequeno e está restrito ao setor caudolateral da APir, no nível imediatamente posterior ao desaparecimento do núcleo amigdalóide cortical póstero-medial (Fig. 7). A injeção está centrada nas lâminas II e III, acometendo parcialmente a camada FIGURA 3 I (Fig. 3D). Como em outros casos que não envolveram apreciavelmente a camada I da APir, o córtex piriforme e os núcleos amigdalóides cortical anterior, cortical póstero-lateral e cortical póstero-medial apresentam-se sensivelmente menos marcados.

No córtex cerebral, a marcação retrógrada está presente em áreas 

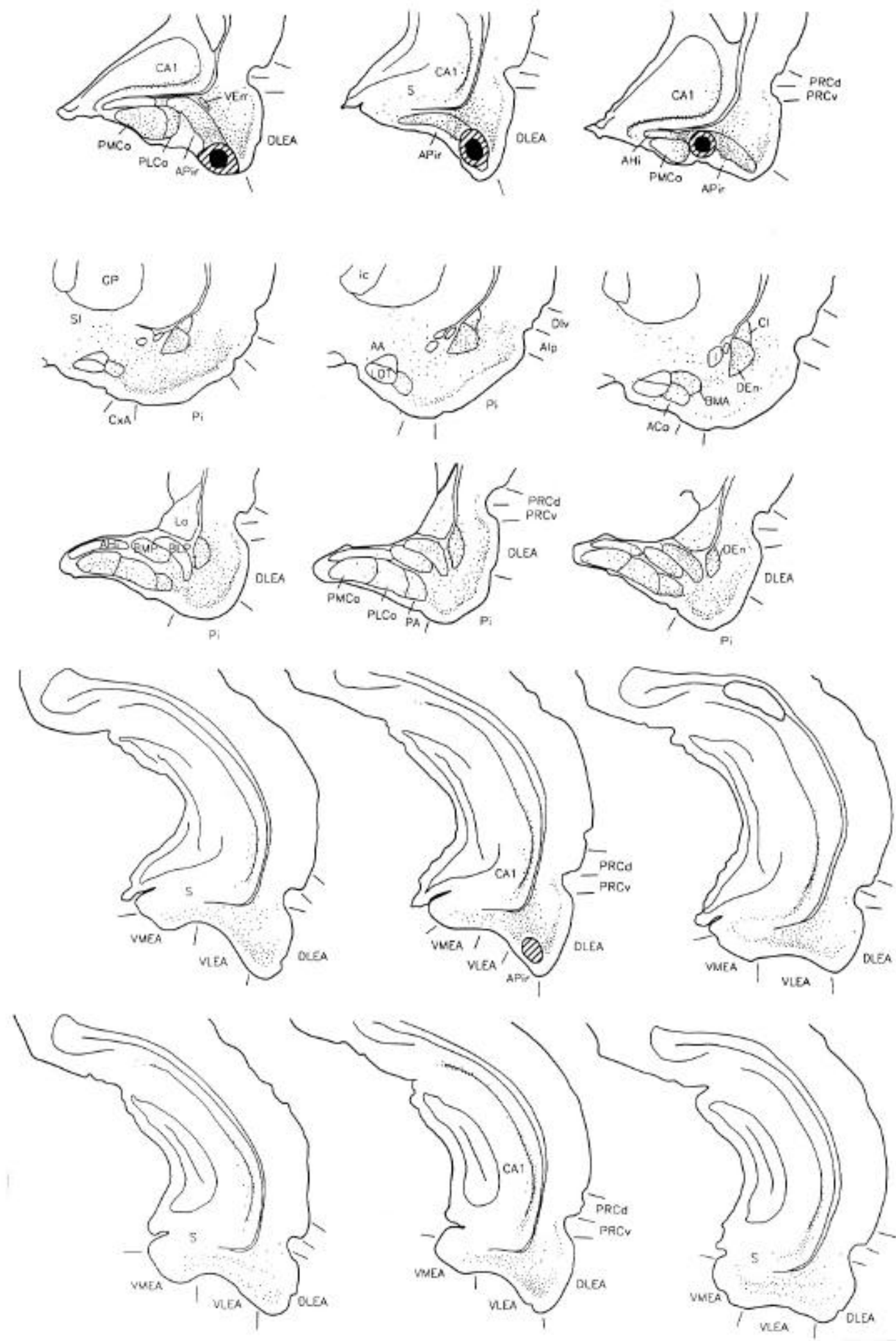

FIGURA 7. Representação semi-esquemática de cortes frontais selecionados ilustrando diferenças na distribuição da marcação retrógrada entre os casos localizados na APir lateral (207 e 247) e na APir medial (264). Na porção superior de cada coluna estão ilustrados os locais de injeção dos casos (que também podem ser observados nas fotomicrografias da figura 3) sendo que a área preta representa o centro do local de injeção e a área hachurada denota a região com depósito de traçador menos denso. 
meso e alocorticais. Foi observada uma densa marcação retrógrada na área insular agranular posterior (principalmente nas lâminas II e III), nos córtices piriforme e entorrinal lateral (principalmente nas lâminas Ilb e $V$, mas também nas lâminas III e VI), no campo CA1, principalmente na sua porção temporal e na porção mais caudal do subiculum. No córtex piriforme, a marcação retrógrada é mais numerosa em sua porção caudal e apresenta-se bilateralmente distribuída em sua porção rostral. No córtex entorrinal lateral, a marcação retrógrada é mais abundante em suas subdivisões ventrolateral e dorsolateral e diminui gradativamente em direção caudal. Um grande número de pericários marcados foi encontrado na porção dorsal do núcleo endopiriforme, estando sua porção ventral mais modestamente marcada. $O$ claustrum, a tenia tecta e os setores dorsomedial e posterior do núcleo olfativo anterior apresentaram poucas células marcadas. Neurônios retrogradamente marcados foram notados na subdivisão ventromedial do córtex entorrinal, no córtex perirrinal (principalmente na sua porção ventral), na porção visceral do córtex disgranular. Uma marcação retrógrada escassa foi ainda detectada no subiculum ventral e dorsal, e no parasubiculum.

$\mathrm{Na}$ amígdala, as regiões que apresentam marcação retrógrada mais proeminente são o núcleo basomedial anterior e a porção rostral do núcleo basolateral posterior. Diferentemente do caso 94, onde a marcação do núcleo basolateral posterior continua sem transição aparente com a marcação que recobre a porção rostral da APir, no caso 247 , a marcação no núcleo basolateral posterior diminui bruscamente nas imediações da abertura do ventrículo lateral. Como já mencionado, a marcação retrógrada observada 
nos núcleos amigdalóides cortical anterior, cortical póstero-lateral e cortical póstero-medial é mais modesta do que a de outros casos cuja injeção envolveu a camada molecular da APir. Um número moderado de células retrogradamente marcadas foi visto na área amigdalóide anterior, na área amígdalo-piriforme de Swanson (1992), no núcleo amigdalóide medial e na porção lateral do núcleo basomedial posterior. No núcleo amigdalóide medial, os neurônios marcados distribuem-se nas divisões ântero-ventral, pósteroventral e também na divisão póstero-dorsal, onde se encontram agrupados sob a forma de uma massa compacta de pequenas células. Escassos pericários marcados foram ainda detectados nos núcleos basolateral ventral, lateral (principalmente na porção ventromedial), central e na área amígdalohipocampal.

Outras estruturas telencefálicas que apresentaram uma marcação retrógrada modesta foram o núcleo da banda diagonal de Broca, a substância inominada sublenticular, o pálido ventral, a área septal medial e o núcleo préóptico magnocelular.

No hipotálamo, uma marcação retrógrada modesta foi observada nos núcleos ventromedial, hipotalâmico posterior e supramamilar lateral e na área hipotalâmica lateral, principalmente em seu setor póstero-lateral.

No tálamo, a marcação retrógrada está concentrada em núcleos da linha média. O principal foco de marcação localiza-se na porção mais caudal do núcleo central medial (segundo o atlas de Swanson, 1992), dorsalmente ao núcleo subparafascicular magnocelular. Neurônios retrogradamente marcados foram também observados no núcleo reuniens e, em bem menor 
número, no núcleo paraventricular anterior e posterior, na porção parvicelular do núcleo ventropóstero-medial, que corresponde ao relé talâmico gustativo, na região ventromedial do núcleo parafascicular e no complexo posterior do tálamo.

No tronco cerebral, os núcleos dorsal da rafe e locus coeruleus, e a área parabraquial possuem um número moderado de neurônios retrogradamente marcados. Na área parabraquial, a marcação está localizada principalmente no subnúcleo medial, apresentando também algumas células marcadas na "área da cintura" (waist area). Uma modesta marcação retrógrada foi também observada contralateralmente no locus coeruleus. Neurônios retrogradamente marcados foram ainda notados na área tegmental ventral e no núcleo linear caudal da rafe.

\subsubsection{Caso 207}

O depósito de FG neste caso também foi menor do que no caso 94 e FIGURA 7 está restrito à região lateral da APir (Fig. 7). A injeção se localiza em um nível bem mais rostral do que no caso 247 (descrito anteriormente) e envolveu

FIGURA3 plenamente as camadas I e II da APir lateral (Fig. 3C). Em função da laminação e do nível ântero-posterior acometidos, notamos algumas diferenças na distribuição e intensidade da marcação retrógrada em determinadas estruturas.

Seguindo o padrão dos casos que envolveram a camada I (lâminas la e lb) da APir, podemos observar marcação retrógrada na camada de células mitrais do bulbo olfativo. O córtex piriforme e o núcleo endopiriforme dorsal apresentam-se mais densamente marcados assim como os núcleos 
amigdalóides cortical anterior, cortical póstero-lateral e cortical pósteromedial.

Dentre as outras estruturas do complexo amigdalóide, notamos um número muito modesto de neurônios retrogradamente marcados no núcleo basolateral posterior, dispostos na porção rostral deste núcleo.

$\mathrm{Na}$ formação hipocampal, a marcação retrógrada abarca uma menor extensão do campo CA1, e no subiculum e no córtex perirrinal parece ser menos densa do que a observada no caso 247.

\subsection{Injeções na APir medial}

Os experimentos com injeções confinadas ao setor medial da APir (casos 264 e 265) revelaram um quadro de aferências que difere em alguns aspectos do padrão descrito nos casos com injeção na região lateral da APir

FIGURA 7 (Fig. 7). A característica mais marcante observada nos casos com depósito do traçador na APir medial é a quase total ausência de marcação retrógrada nas áreas mesocorticais. $\mathrm{Na}$ amígdala, notamos que o núcleo basolateral posterior apresenta células retrogradamente marcadas em toda a sua extensão enquanto que nos casos com injeção na APir lateral, a marcação retrógrada está confinada à porção rostral do referido núcleo. A distribuição dos neurônios marcados na formação hipocampal ocupa uma posição mais ventral (temporal) do que a observada nos casos com injeção na região lateral da APir (Fig. 7).

\subsubsection{Caso 264}

Este caso apresenta uma injeção restrita à porção medial da APir, 
FIGURA 3

FIGURA 7

com um pequeno depósito de FG que está centrado na camada II e acomete discretamente a camada I deste território (Fig. 3B e 7).

No córtex cerebral, a marcação retrógrada se concentra nas áreas alocorticais, evitando de um modo geral as áreas mesocorticais. Um número substancial de células retrogradamente marcadas foi observado nos córtices piriforme e entorrinal lateral, no campo CA1 temporal e no subiculum ventral, particularmente em seu setor mais caudal. No córtex piriforme, notamos que a marcação retrógrada se distribui mais expressivamente no seu setor caudal do que no seu setor rostral. Observamos muitos neurônios retrogradamente marcados no núcleo endopiriforme dorsal e um número mais modesto no núcleo endopiriforme ventral, no claustrum e nos setores dorsomedial e posterior do núcleo olfativo anterior. Notamos marcação retrógrada mais escassa na porção posterior do córtex insular agranular (distribuída nas camadas profundas), no córtex perirrinal, e no parasubiculum.

$\mathrm{Na}$ amígdala, os núcleos basomedial anterior e basolateral posterior são as fontes de aferências mais importantes. Neste caso, assim como no caso 94 (depósito extenso na APir), o núcleo basolateral posterior apresenta densa marcação retrógrada em toda a sua extensão. Um número substancial de neurônios marcados é observado nos núcleos amigdalóides cortical anterior, cortical póstero-lateral e cortical póstero-medial. Notamos uma marcação retrógrada mais modesta na área amigdalóide anterior, na área amígdalo-piriforme de Swanson (1992), nos núcleos amigdalóides medial, basomedial posterior (porção lateral), lateral (principalmente na sua divisão ventromedial) e basolateral ventral, assim como na área amígdalo- 
hipocampal. No núcleo amigdalóide medial, os neurônios marcados distribuem-se nas divisões ântero-ventral, ântero-dorsal, póstero-ventral e, como observado em outros casos, na divisão póstero-dorsal, eles se encontram agrupados sob a forma de uma massa compacta de pequenas células. Poucos pericários marcados foram detectados ainda no núcleo amigdalóide central e no núcleo intersticial da estria terminal.

A marcação retrógrada observada no diencéfalo e no tronco cerebral é semelhante à descrita nos casos com injeção na APir lateral.

\subsubsection{Caso 265}

Neste experimento, a injeção de FG está confinada à porção mais medial da APir e consiste em um pequeno depósito de traçador centrado na camada II e que envolve apreciavelmente a camada I. Além do maior comprometimento da camada I, o setor da APir medial acometido neste caso é mais rostral e mais medial em relação ao caso 264 acima descrito. Em função destes fatores, notamos algumas diferenças na distribuição e intensidade da marcação retrógrada em determinadas estruturas.

Como nos outros casos que envolveram a camada I da APir, evidenciamos marcação retrógrada na camada de células mitrais do bulbo olfativo; o córtex piriforme e o núcleo endopiriforme dorsal apresentam-se mais densamente marcados assim como os núcleos amigdalóides cortical anterior e cortical póstero-lateral.

No complexo amigdalóide, observamos ainda um aumento do número de pericários retrogradamente marcados no núcleo medial (mais acentuado na 
divisão póstero-ventral) e na área amígdalo-hipocampal, provavelmente devido a um envolvimento periférico do núcleo cortical póstero-medial.

\subsection{Injeção na APir Caudal}

No caso 89, a injeção de CTb está localizada no setor caudal da APir FIGURA 2 (centrado nas camadas II e III) (Fig. 2), em um nível imediatamente rostral ao aparecimento do córtex entorrinal ventrolateral que se caracteriza por uma FIGURA 1 compactação bastante evidente da lâmina II (Fig. 1C). De um modo geral, a marcação retrógrada observada neste caso anuncia o padrão de marcação típico dos casos com injeção no córtex entorrinal ventrolateral. No córtex cerebral, a área insular agranular posterior está praticamente desprovida de marcação retrógrada; por outro lado, o parasubiculum possui um número apreciável de células retrogradamente marcadas. Na amígdala, chama particularmente a atenção o fato do núcleo basolateral posterior estar apenas modestamente marcado, enquanto que os núcleos amigdalóides lateral (principalmente as divisões dorsolateral e ventromedial), medial e basomedial

posterior possuem uma marcação retrógrada mais expressiva do que a observada nos outros casos com injeção na APir. Dentre os núcleos talâmicos, o reuniens é aquele que exibe marcação retrógrada mais pronunciada. Apenas um ou outro neurônio ocasional foi detectado na área parabraquial. 


\subsection{Outros Casos}

\subsubsection{Injeção na porção caudal do núcleo amigdalóide basolateral} posterior

O caso 61 possui um depósito de CTb confinado à porção mais caudal do núcleo amigdalóide basolateral posterior. O padrão de marcação retrógrada observado neste caso é muito semelhante ao padrão de outros casos com injeção de CTb na APir. Entretanto, no caso 61, o bulbo olfativo é desprovido de marcação retrógrada e as estruturas olfativas (córtex piriforme, núcleo endopiriforme dorsal e núcleos amigdalóides cortical anterior e cortical póstero-lateral) são de um modo geral menos marcadas do que nos casos com injeção na APir. Uma densa marcação retrógrada foi observada na APir na caso 61, que desvanece abruptamente ao nível do córtex entorrinal lateral. A marcação retrógrada na área parabraquial no caso 61 é mais densa do que a observada em experimentos com injeção na APir e está localizada nos subnúcleos medial, ventral lateral, externo-lateral e na área da cintura.

\subsection{Casos com injeções no córtex entorrinal lateral}

Em 9 experimentos obtivemos injeções localizadas na subdivisão dorsolateral, ventrolateral ou ventromedial do córtex entorrinal lateral (ver parcelamento citoarquitetônico de Krettek e Price, 1977). 


\subsubsection{Injeções no córtex entorrinal dorsolateral e ventrolateral}

Foram obtidos 2 casos (118 e 119) com depósito de FG na divisão dorsolateral do córtex entorrinal. No caso 118, o local de injeção está centrado na lâmina II, acometendo também as lâminas I e III, e se localiza no setor rostral do córtex entorrinal dorsolateral, adjacente à APir. No caso 119, o depósito de FG está na porção do córtex entorrinal dorsolateral imediatamente caudal à APir e acomete principalmente as camadas FIGURA 2 profundas (IV, V e VI) (Fig. 2).

Entre os 4 casos que atingiram a subdivisão ventrolateral do córtex entorrinal lateral, 2 possuem depósitos de CTb (101 e 104) e 2 apresentam injeções de FG (100 e 114; Fig. 2). Nos casos 101 e 104, o depósito de CTb está localizado nas camadas profundas do córtex entorrinal ventrolateral. Todas as estruturas retrogradamente marcadas nestes casos foram

FIGURA 9 identificadas no caso 114 (Fig. 9) que possui uma injeção de FG localizada no mesmo território. No caso 114, o depósito do traçador está localizado nas camadas profundas (camadas III, IV e V) do setor ventrolateral do córtex

FIGURA 8 entorrinal (Fig. 2 e 8). No caso 100, o depósito de FG está situado mais superficialmente do que no caso 114 e envolve as lâminas I, II e III (Fig. 2).

À semelhança do que foi observado nos experimentos da série APir, nos casos onde o depósito do traçador envolve a camada mais superficial do córtex entorrinal lateral (casos 100 e 118), notamos uma marcação retrógrada nas células mitrais do bulbo olfativo e um aumento substancial na quantidade de células marcadas em toda a extensão do córtex piriforme, além da 


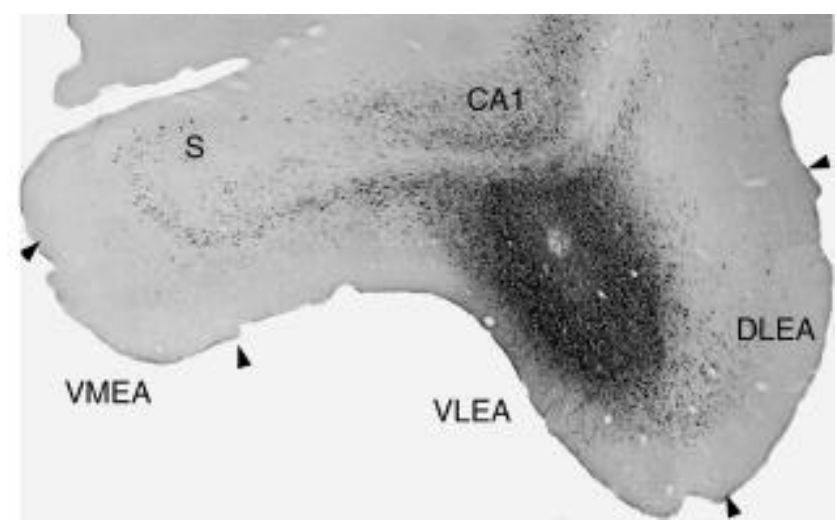

FIGURA 8. Fotomicrografia em campo claro ilustrando o depósito de FG no córtex entorrinal ventrolateral no caso 114. 


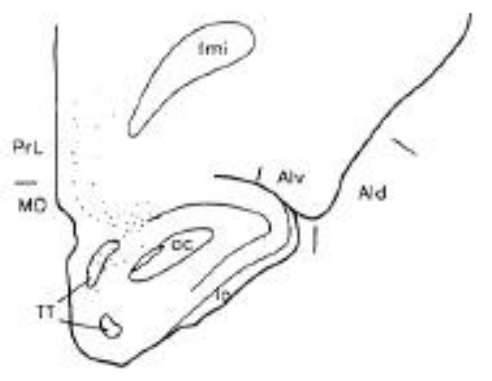

A

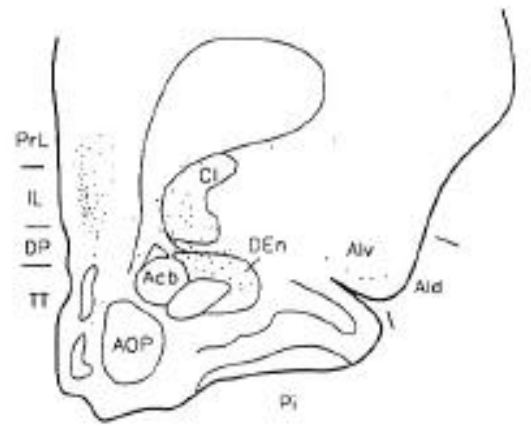

B

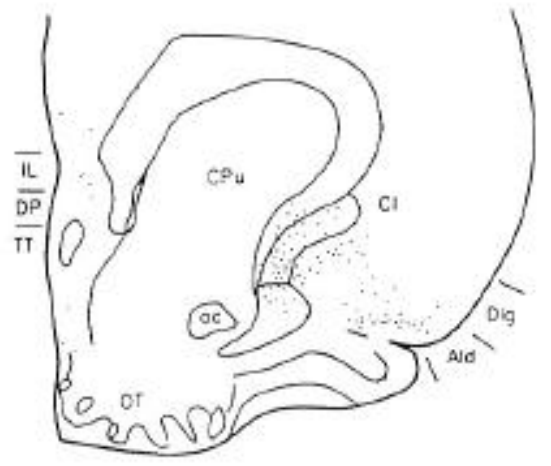

C

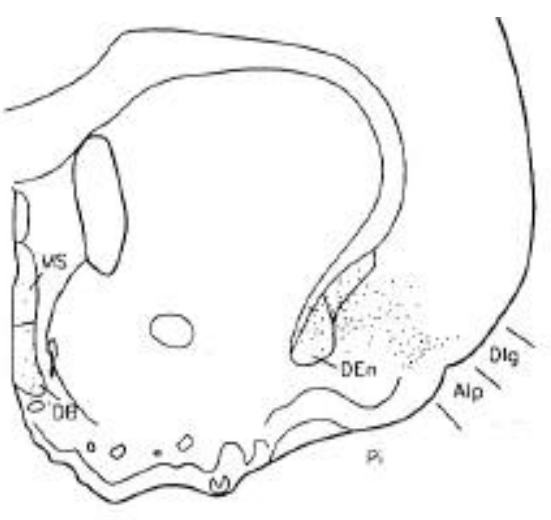

D

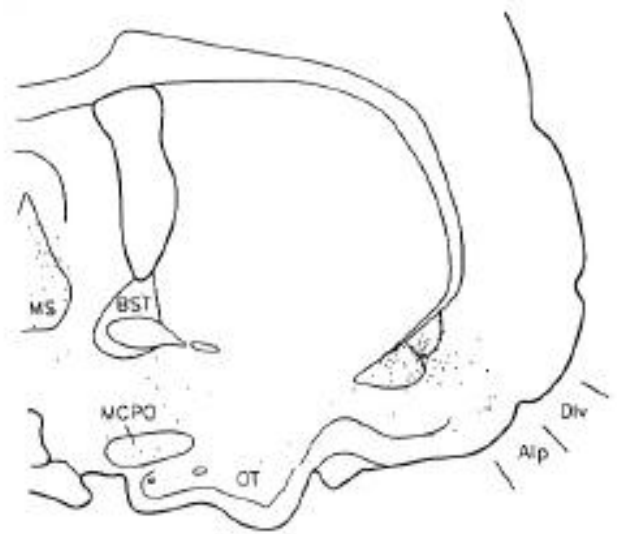

E

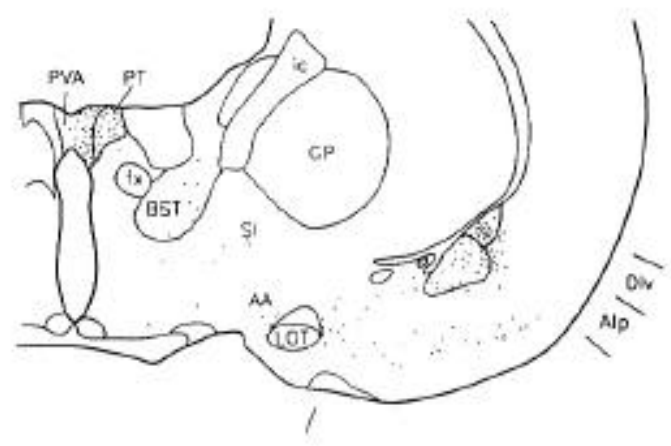

F

FIGURA 9. Representação semi-esquemática de cortes frontais apresentados em sequência rostro-caudal mostrando a distribuição dos neurônios retrogradamente marcados no caso 114, representativo dos experimentos com depósito de FG no córtex entorrinal ventrolateral. Em (N) a área preta representa o centro do local de injeção e a área hachurada denota a região com depósito de traçador menos denso. Uma fotomicrografia deste local de injeção é ilustrado na figura 8. 


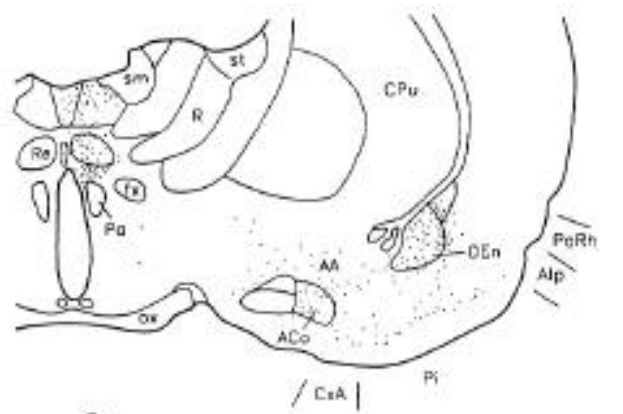

G

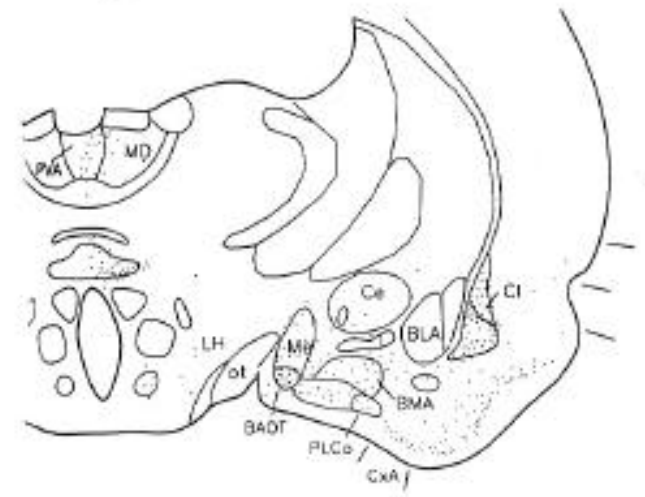

$\mathrm{H}$

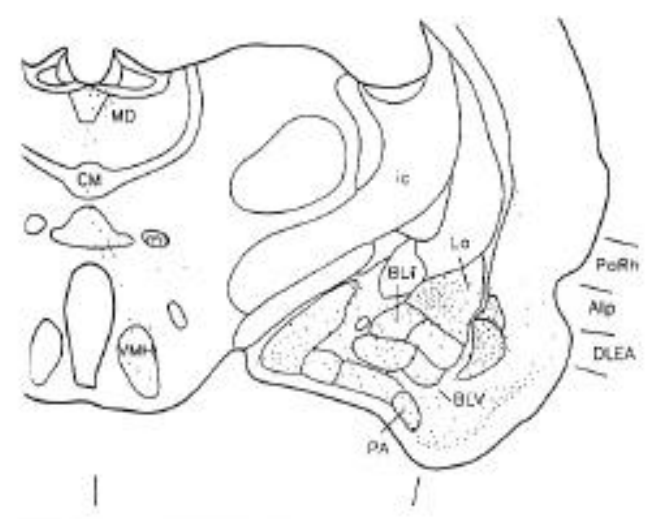

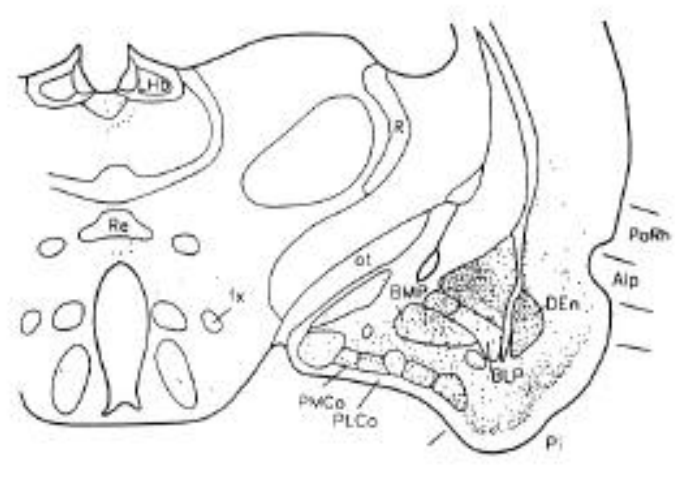

J

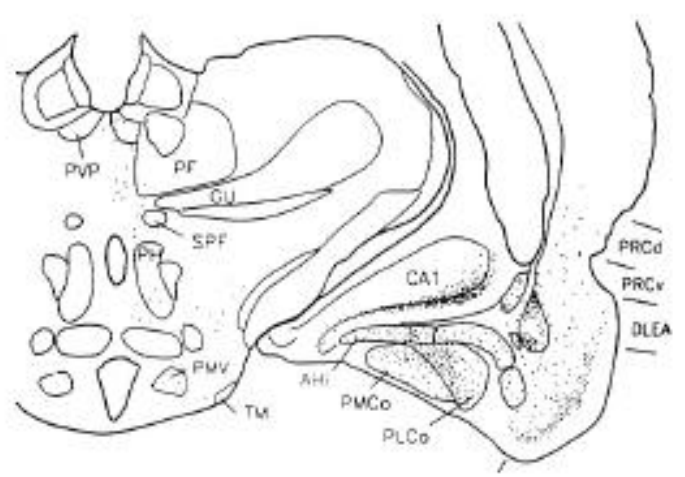

K

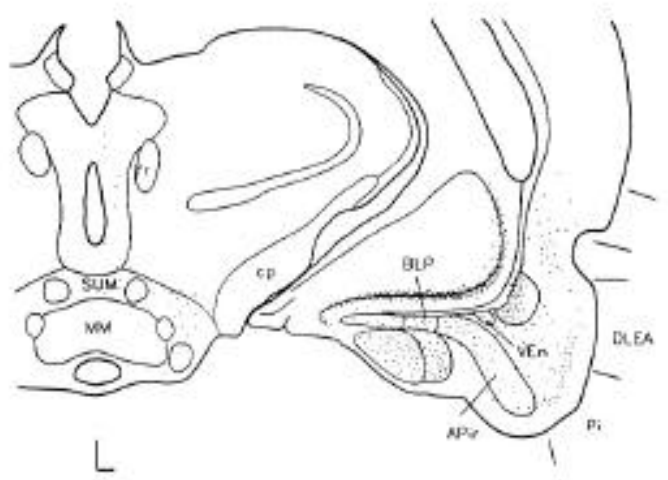

CONTINUAÇÃO DA FIGURA 9. 

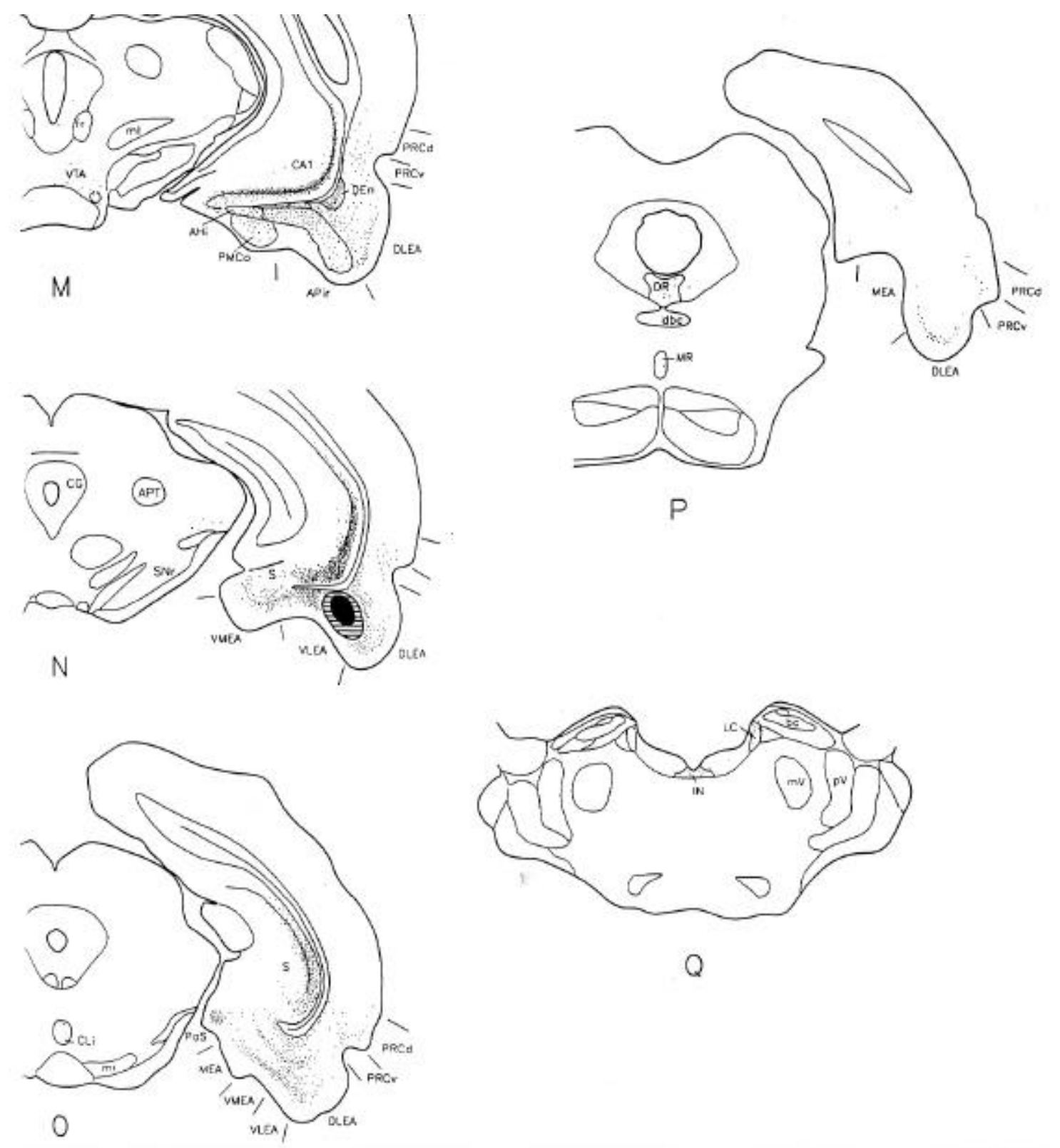

CONTINUAÇÃO DA FIGURA 9. 
presença de uma marcação bilateral na sua porção mais rostral. No caso 100, é interessante ainda notar que a área amígdalo-hipocampal está virtualmente desprovida de marcação retrógrada e que os pericários observados na camada II da APir formam agregrados celulares intensamente marcados.

O conjunto das aferências observado nos casos com injeções de traçador nas subdivisões dorsolateral e ventrolateral do córtex entorrinal é muito semelhante. Em função disso, a descrição das fontes de aferências destes dois territórios será agrupada. O caso 114, com depósito no córtex

FIGURA 8 FIGURA 9

entorrinal ventrolateral (Fig. 8 e 9), será tomado como protótipo desse grupo experimental (ver Tabela 1) e as diferenças encontradas entre as aferências deste território e as do córtex entorrinal dorsolateral serão comentadas a seguir.

\subsubsection{Caso 114}

A injeção de FG neste caso está localizada no córtex entorrinal ventrolateral, imediatamente caudal à APir, estando centrada nas lâminas mais profundas, o depósito praticamente não acometeu a lâmina I (Fig. 8 e $9 N)$.

Uma densa marcação retrógrada foi observada na porção posterior do córtex piriforme (principalmente na lâmina II e também na III) (Fig. 9F-L) e na formação hipocampal: no campo temporal CA1, subiculum ventral, parasubiculum, e córtex entorrinal lateral, principalmente nas lâminas II e V das subdivisões ventrolateral e ventromedial (Fig. 9K-P). Um número substancial de células retrogradamente marcadas foi também encontrado no 
FIGURA 9 área insular (todas as camadas) (Fig. 9B-D), no córtex perirrinal, principalmente na região do fundo da fissura rinal (lâminas II, III e V) (Fig. 9LP), e na APir (lâminas II e III) (Fig. 9K-P), e, em bem menor quantidade, na divisão agranular dorsal da área insular (lâmina II), nas áreas orbital medial e ventral (lâminas II e III), no córtex pré-límbico (lâminas II e III) (Fig. 9A-C) assim como na porção dorsal do córtex perirrinal (lâminas II e V) (Fig. 9K-P) e no pós-subiculum. A marcação retrógrada é ipsolateral salvo na face medial do hemisfério cerebral onde é bilateralmente distribuída. Na APir as células marcadas são mais numerosas em seu setor caudomedial (Fig. 9M). Uma marcação retrógrada abundante foi notada no núcleo endopiriforme dorsal, extendendo-se até o setor ventral do claustrum (Fig. 9B-M).

Dentre os núcleos do complexo amigdalóide, o núcleo lateral é o mais densamente marcado; as células retrogradamente marcadas estão principalmente localizadas na divisão ventromedial deste núcleo (Figs. 9I-K e FIGURA 5 5B). Uma marcação retrógrada muito substancial foi também notada no núcleo intersticial do trato olfativo acessório, no núcleo amigdalóide medial, principalmente na sua divisão póstero-ventral, e na porção caudal do núcleo basolateral anterior (que corresponde ao núcleo basolateral intermédio de Savander e cols., 1995), bem como nos núcleos basomedial posterior, cortical póstero-lateral, cortical póstero-medial e na área amígdalo-hipocampal (Fig. 9H-M). A área amigdalóide anterior, a área de transição córtico-amigdalóide, os núcleos cortical anterior, basomedial anterior, basolateral ventral, 
basolateral posterior e a área amígdalo-piriforme de Swanson (1992) contêm FIGURA 9 marcação retrógrada de densidade modesta a moderada (Fig. 9F-J). Alguns pericários marcados foram ainda detectados na divisão medial do núcleo intersticial da estria terminal, na substância inominada sublenticular e no núcleo amigdalóide central (Fig. 9F-J).

Outras estruturas telencefálicas que apresentam neurônios retrogradamente marcados são a região dorsomedial do núcleo olfativo anterior, a tenia tecta, a área septal medial, o núcleo da banda diagonal de Broca e o núcleo pré-óptico magnocelular (Fig. 9A-E).

No tálamo, o mais denso foco de marcação retrógrada foi observado no núcleo reuniens, devendo ser notado que os pericários marcados concentram-se no setor rostro-ventral deste núcleo (Fig. 9G-J). Notamos ainda um denso aglomerado de células retrogradamente marcadas situado ventralmente à porção rostral do núcleo reuniens e dorsalmente ao núcleo paraventricular do hipotálamo (Fig. 9G). Marcação retrógrada muito proeminente foi também encontrada no núcleo paratenial e na porção rostral do núcleo paraventricular anterior (Fig. 9F-I). Um pequeno número de neurônios retrogradamente marcados foi ainda visto nos núcleos rombóide, paraventricular posterior, intermédio-dorsal, central medial, na divisão medial do núcleo médio-dorsal, na porção parvicelular do núcleo subparafascicular, no núcleo intralaminar posterior e na área peripeduncular (Fig. 9H-N).

No hipotálamo, neurônios retrogradamente marcados foram observados na região supramamilar lateral e na área hipotalâmica lateral e, em menor número, nos núcleos ventromedial, posterior, pré-mamilar ventral e 
túbero-mamilar (bilateralmente) (Fig. 9H-L).

No tronco cerebral, uma marcação retrógrada substancial foi

FIGURA 9 observada nos núcleos dorsal da rafe, locus coeruleus e incerto (Fig. 9P-Q). No locus coeruleus, a marcação está situada principalmente na região dorsal e é bilateralmente distribuída com predominância ipsolateral. Alguns neurônios retrogradamente marcados foram além disso encontrados na substância cinzenta periventricular, na área tegmental ventral, no campo retrorrubral, nos núcleos linear caudal e mediano da rafe e na divisão dorsomedial do núcleo interpeduncular (Fig. 9M-Q). A área parabraquial é desprovida de marcação.

\subsubsection{Caso 119}

Neste caso, o depósito de FG situa-se na porção do córtex entorrinal dorsolateral, caudalmente à APir, e acomete principalmente as camadas FIGURA 10 profundas (IV, V e VI) (Fig. 10R). O caso 119 (ilustrado na Fig. 10) foi escolhido como representativo da série (ver Tabela 1). Suas aferências são muito semelhantes às do caso 114 com injeção no córtex entorrinal ventrolateral, diferindo apenas quanto à densidade relativa da marcação retrógrada em certas áreas mesocorticais e em alguns núcleos da amígdala e do tálamo.

De um modo geral, toda a extensão do córtex insular agranular (divisões dorsal, ventral e posterior) (Fig. 10A-J) e o córtex perirrinal (setores dorsal e ventral) (Fig. 10L-W) apresentaram marcação retrógrada mais proeminente do que no caso 114 (Fig. 9A-P), com injeção na divisão 


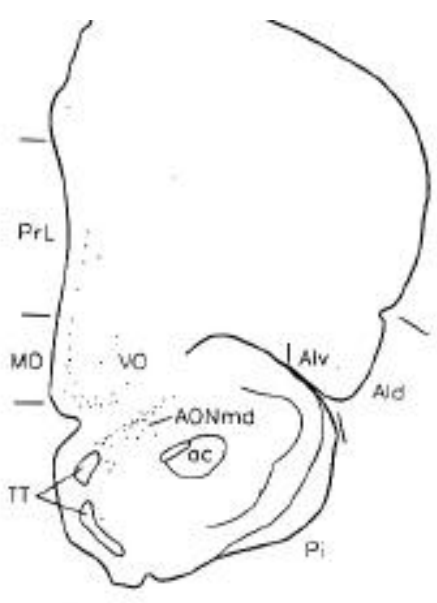

A

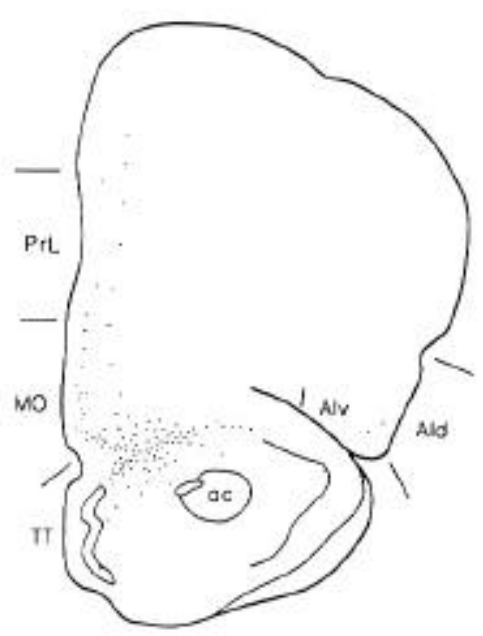

B

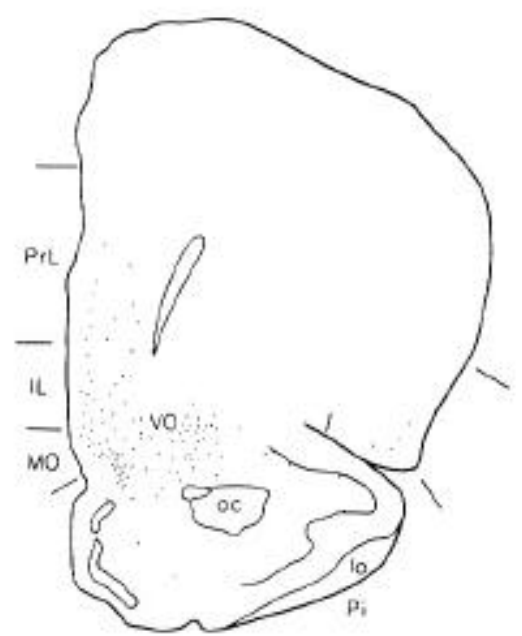

C
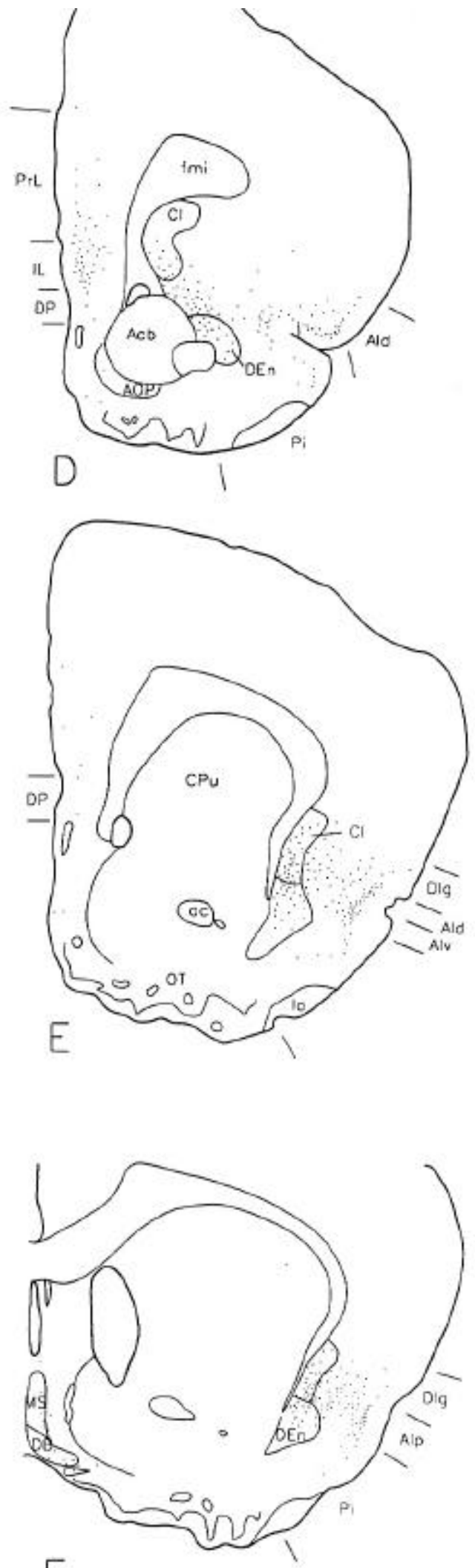

F

FIGURA 10. Representação semi-esquemática de cortes frontais apresentados em sequência rostro-caudal mostrando a distribuição dos neurônios retrogradamente marcados no caso 119, representativo dos experimentos com depósito de FG no córtex entorrinal dorsolateral. Em $(\mathrm{Q}),(\mathrm{R})$ e (S) a área preta representa o centro do local de injeção e a área hachurada denota a região com depósito de traçador menos denso. 

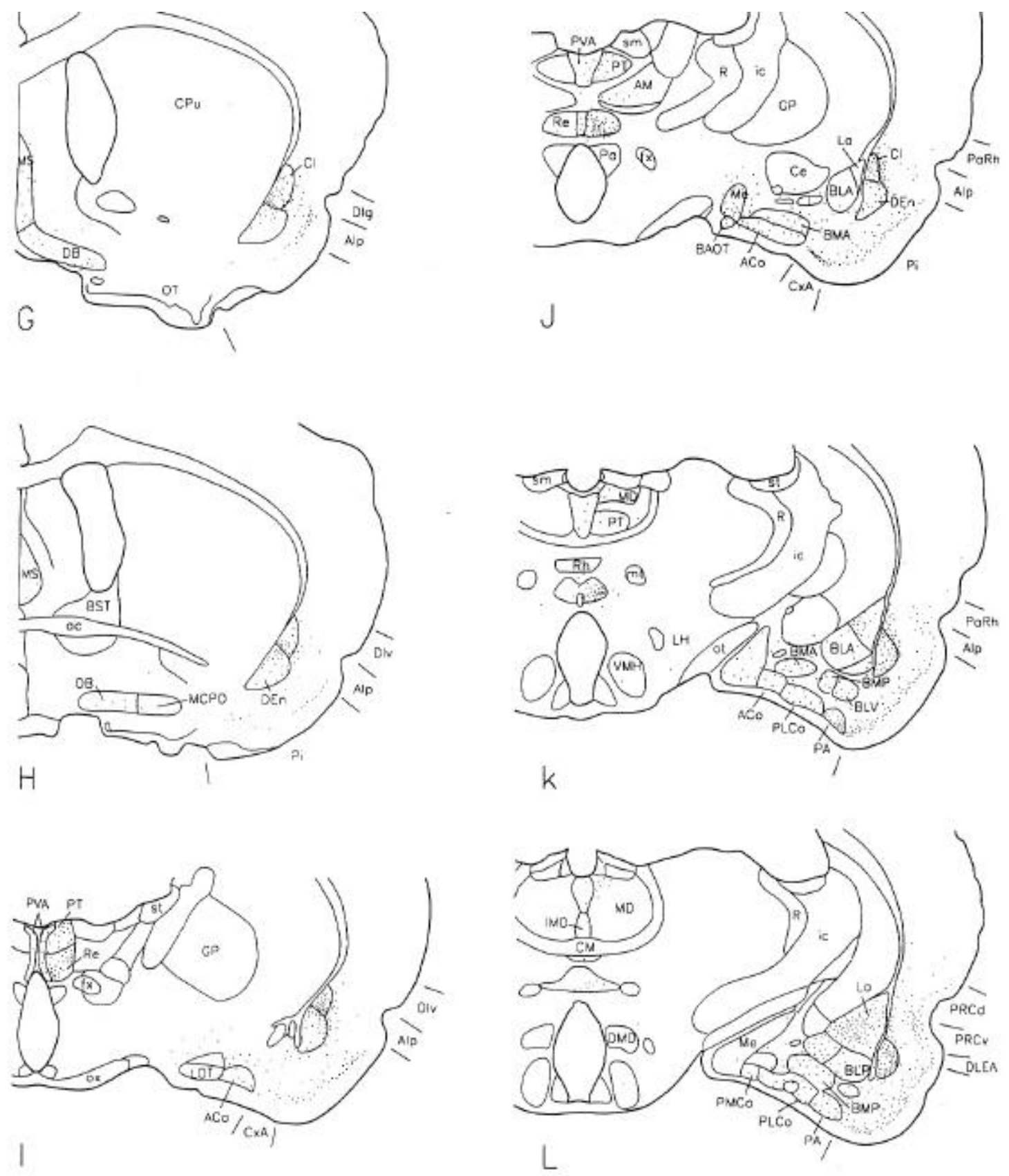

CONTINUAÇÃO DA FIGURA 10. 

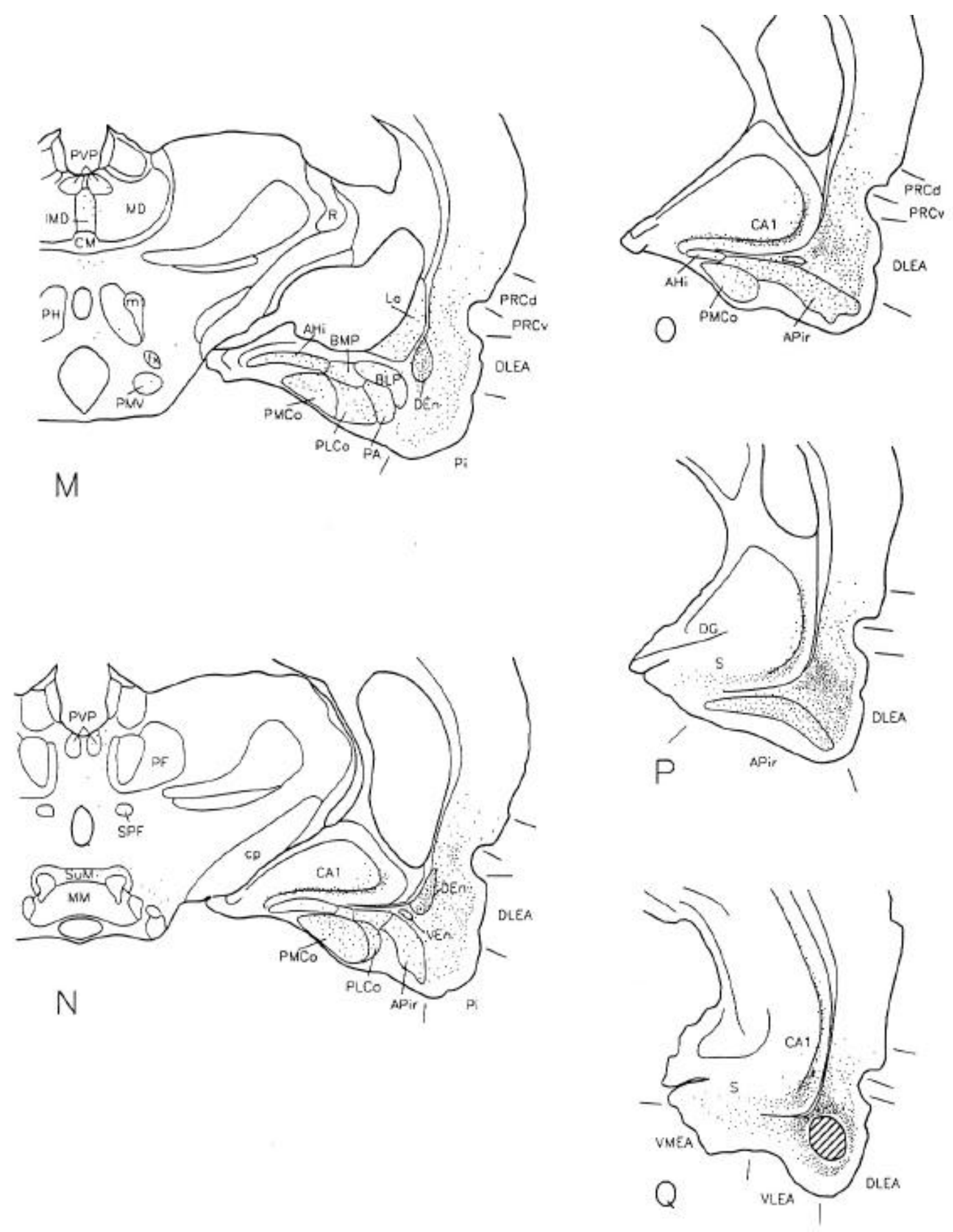

CONTINUAÇÃO DA FIGURA 10. 

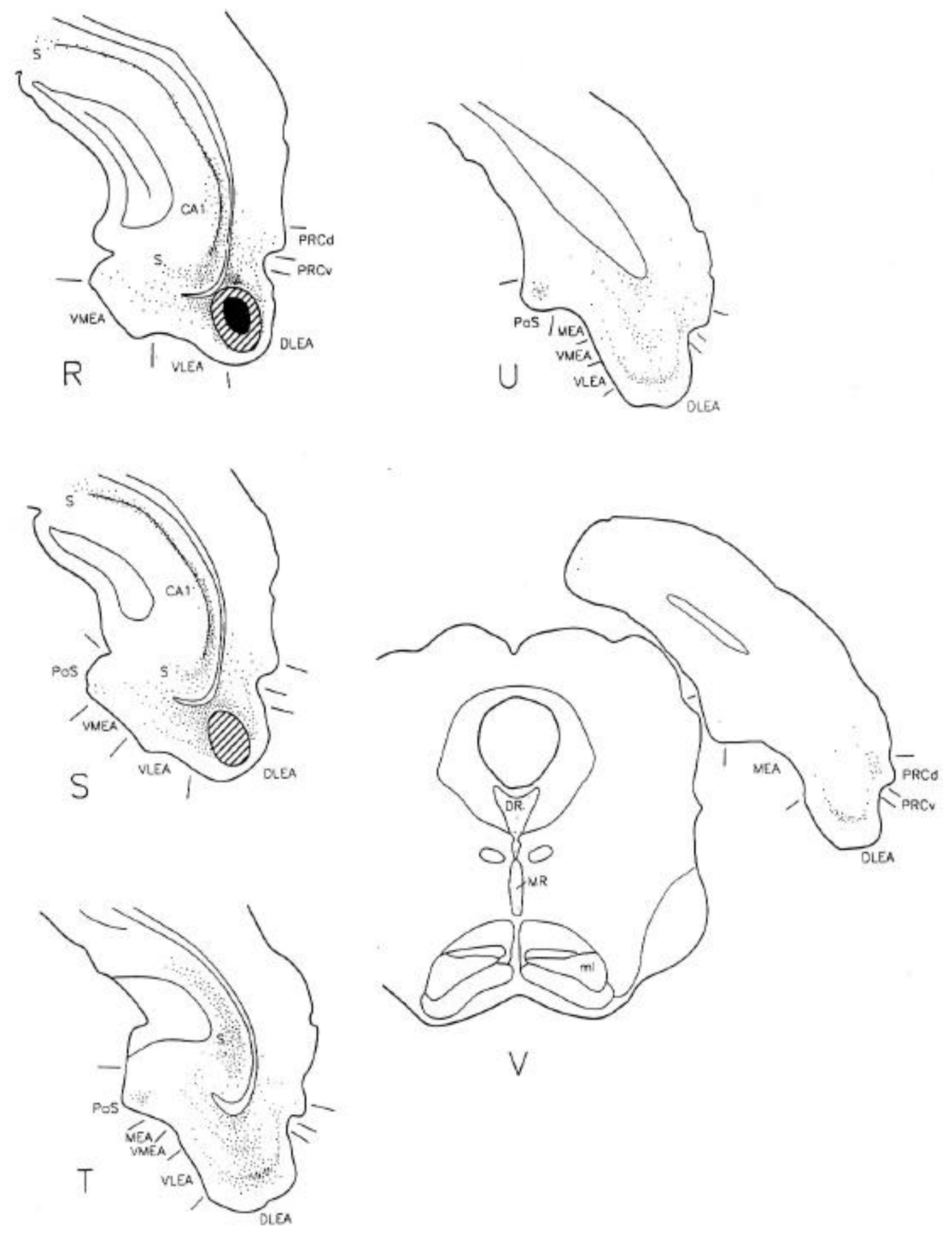

CONTINUAÇÃO DA FIGURA 10. 


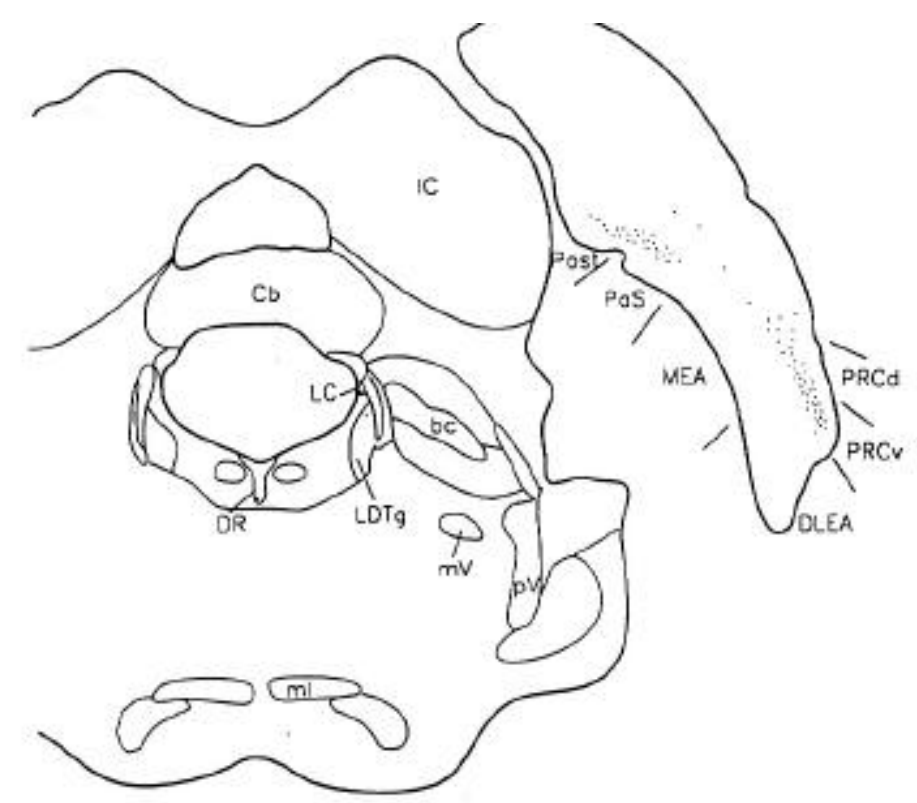

W

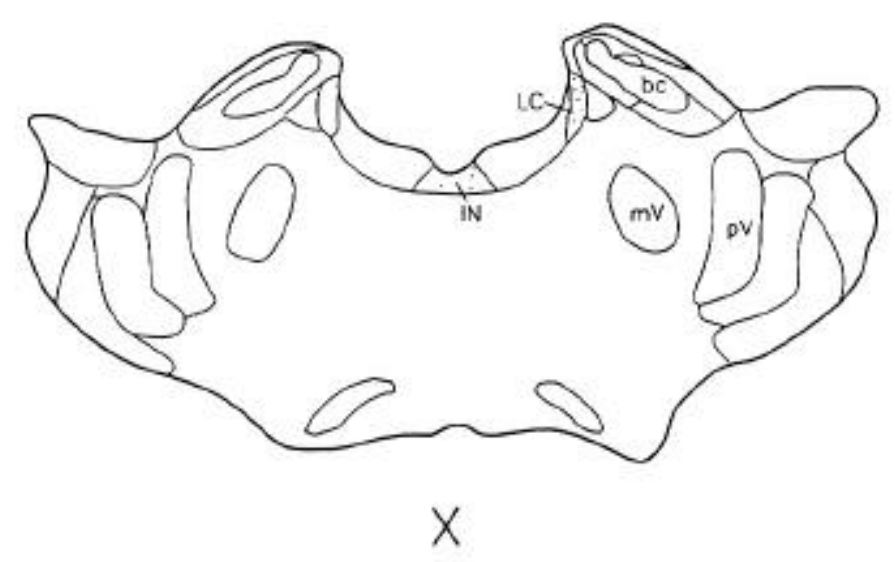

CONTINUAÇÃO DA FIGURA 10. 
ventrolateral do córtex entorrinal lateral. Tanto no caso 114 como no caso 119 foi observada uma marcação retrógrada muito densa na formação hipocampal. Em ambos os casos concentrou-se na campo CA1 temporal e subiculum ventral, porém no caso 119 esta marcação possui uma maior extensão têmporo-septal. De fato, neste caso uma marcação retrógrada relativamente modesta foi também notada no subiculum dorsal e no setor

FIGURA 10 dorsal da porção caudal do campo CA1 (Fig. 10Q-S). Por outro lado, a porção rostral do campo CA1 temporal e o córtex entorrinal ventromedial exibem marcação retrógrada menos densa no caso 119 (Fig. 10N-U) do que no caso FIGURA 9 114 (Fig. 9K-P).

A localização da marcação retrógrada no complexo amigdalóide nos casos 119 e 114 é bastante semelhante, sendo entretanto esta marcação menos densa na maior parte dos núcleos amigdalóides no caso 119 (injeção na subdivisão dorsolateral) (Fig. 10I-P) do que no caso 114 (Fig. 9F-M) (injeção na subdivisão ventrolateral). É importante ressaltar que a principal fonte de aferência amigdaliana para estes territórios corticais se origina no núcleo amigdalóide lateral. Notamos ainda que a área de transição córticoamigdalóide (Fig. 10J) e o núcleo basolateral ventral (Fig. 10K-L) são mais densamente marcados no caso 119 do que no caso 114. No núcleo basolateral ventral, a marcação retrógrada é bilateralmente distribuída. $\mathrm{Na}$ APir, os pericários retrogradamente marcados foram observados em toda a extensão mediolateral deste território (Fig. 10N-P), contrastando com a predominância caudomedial evidenciada no caso 114 (Fig. 9L-M).

Três importantes diferenças foram notadas entre os casos 119 e 114 
no que diz respeito à distribuição da marcação talâmica: 1) Em ambos os casos a porção rostral do núcleo reuniens constitui o principal foco de marcação retrógrada talâmica, porém o setor situado ventralmente ao

FIGURA 10 reuniens é desprovido de células marcadas no caso 119 (Fig. 10J-L); 2) A porção medial do núcleo médio-dorsal do tálamo é mais densamente marcada no caso 119 (Fig. 10K-M) do que no caso 114; e 3) o núcleo paraventricular anterior no caso 119 (Fig. 10I-L) possui marcação menos

FIGURA 9 densa do que a observada no caso 114 (Fig. 9F-J). Deve ser mencionado ainda que uma marcação retrógrada muito modesta foi vista no núcleo ântero-dorsal do tálamo no caso 119, não evidenciada nos casos com injeção na subdivisão ventrolateral do córtex entorrinal lateral.

\subsubsection{Injeções no córtex entorrinal ventromedial}

Em 3 casos (110, 115 e 116) obtivemos injeções de FG na divisão ventromedial do córtex entorrinal. De um modo geral a localização do depósito do traçador foi bastante semelhante nesses casos, envolvendo as FIGURA 11 lâminas superficiais e profundas. O caso 115, ilustrado na figura 11, é considerado representativo da série (ver Tabela 1 e será descrito em detalhes. Nos casos 110 e 116, a injeção se localiza em um nível do córtex entorrinal ventromedial imediatamente caudal à APir e acomete as lâminas II e III. Como em todos os outros casos que apresentam menor acometimento da lâmina I, observamos marcação retrógrada menos evidente no bulbo olfativo e na porção rostral do córtex piriforme. 
Os casos com injeções de FG na divisão ventromedial do córtex entorrinal apresentam fontes de aferências menos diversificadas do que os casos que tiveram como alvos as outras subdivisões do córtex entorrinal lateral ou a APir.

\subsubsection{Caso115}

Neste caso o depósito de traçador localiza-se nas camadas

FIGURA 2 FIGURA 11 superficiais (lâminas I, II e III) do córtex entorrinal ventromedial rostral, em um território imediatamente caudal à APir (Fig. 2 e 11J).

A formação hipocampal possui o maior número de neurônios retrogradamente marcados, localizados nos campos temporais CA3 e CA1, no subiculum ventral e na divisão ventrolateral do córtex entorrinal (lâminas Ila, Ilb e VI) (Fig. 11H-J). No campo CA3, a marcação retrógrada é bilateralmente distribuída com predominância ipsolateral (Fig. 11H). Uma marcação retrógrada escassa foi ainda observada na divisão dorsolateral do córtex entorrinal (lâmina II) e no giro denteado (Fig. 11H-K).

Notamos ainda uma marcação retrógrada substancial em estruturas olfativas: nas células mitrais do bulbo olfativo, na porção dorso-medial do núcleo olfativo anterior, no córtex piriforme (principalmente na lâmina II), no núcleo endopiriforme dorsal e, em bem menor grau, na tenia tecta dorsal (Fig. 11A-H). A marcação nessas estruturas olfativas é ipsolateral exceto no córtex piriforme, onde é bilateralmente distribuída.

No complexo amigdalóide, o núcleo cortical póstero-medial, principalmente sua porção rostral, constitui a principal fonte de aferência amigdaliana do córtex entorrinal ventromedial (Fig. 11G-H), seguido pela 

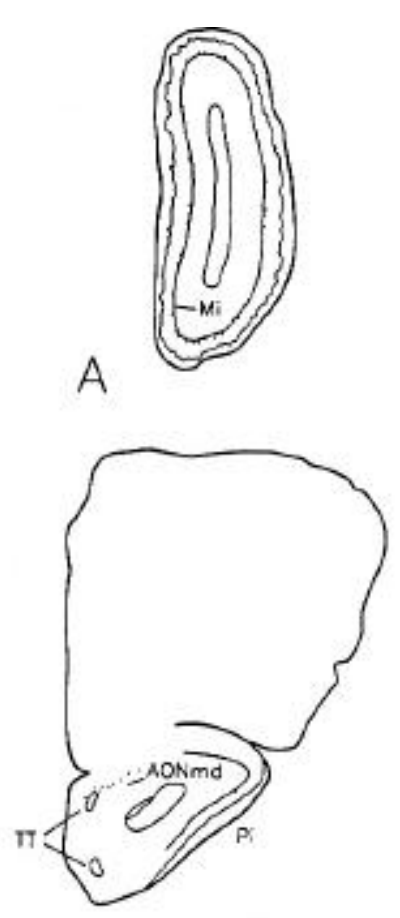

$\mathrm{B}$
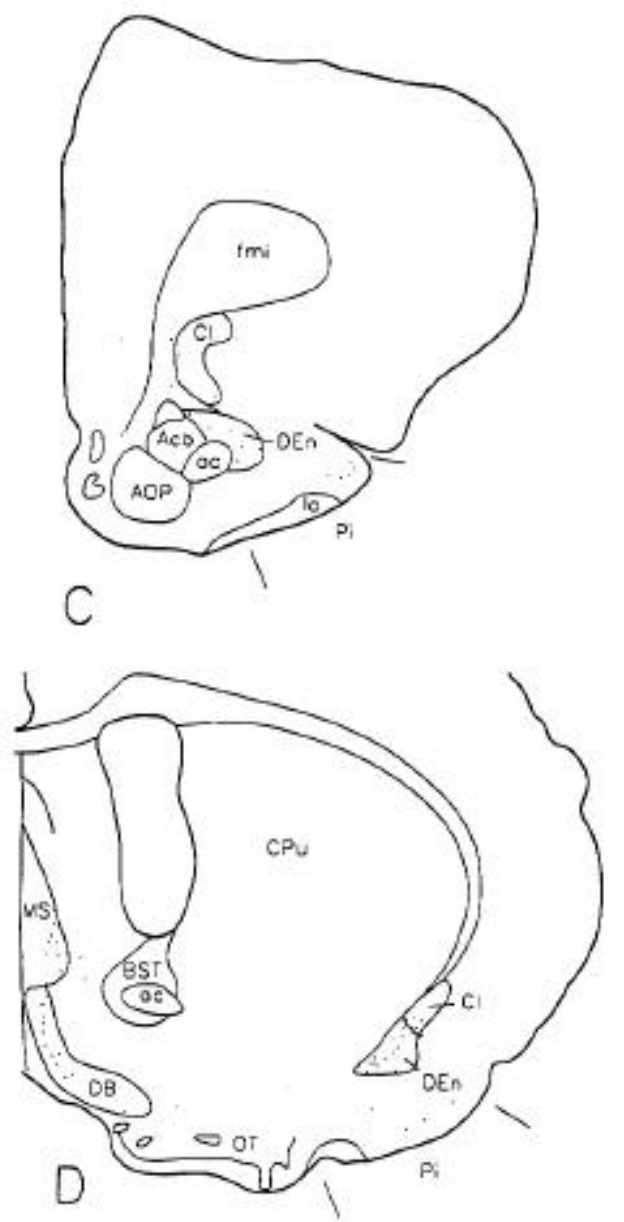
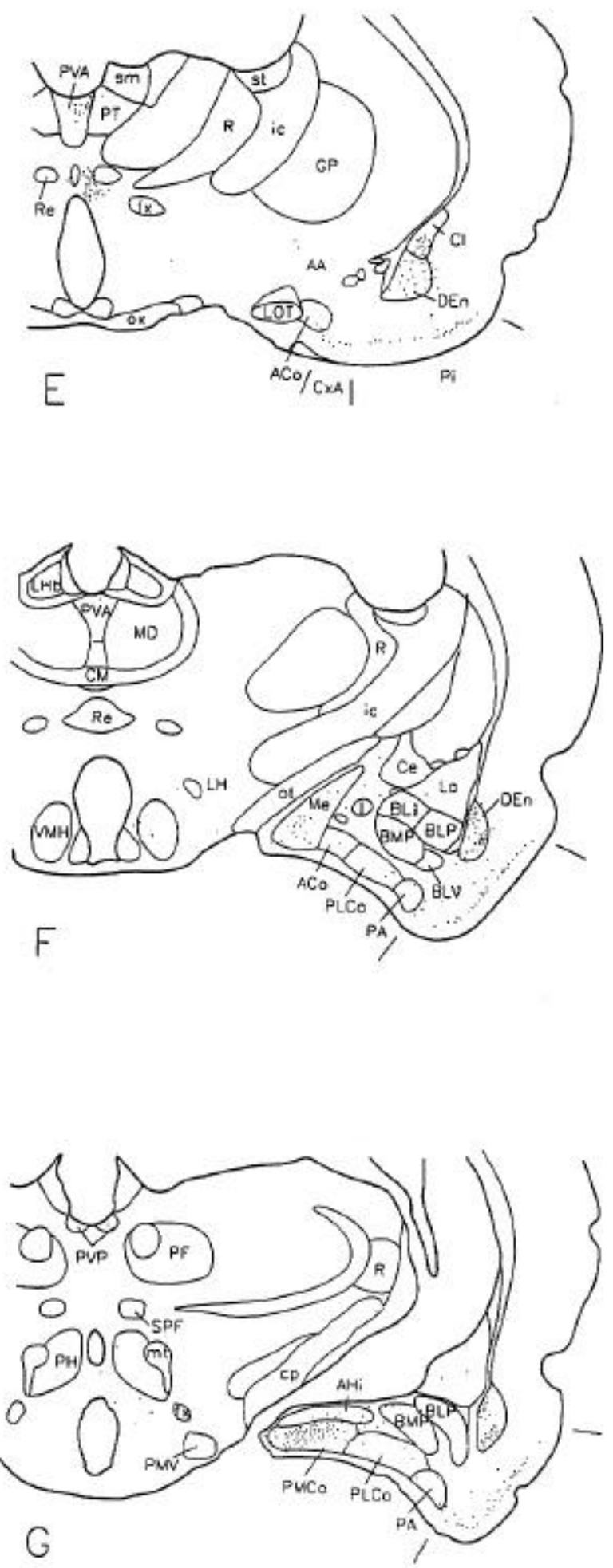

FIGURA 11. Representação semi-esquemática de cortes frontais apresentados em sequência rostro-caudal mostrando a distribuição dos neurônios retrogradamente marcados no caso 115, representativo dos experimentos com depósito de FG no córtex entorrinal ventromedial. Em (I) e (J) a área preta representa o centro do local de injeção e a área hachurada denota a região com depósito de traçador menos denso. 

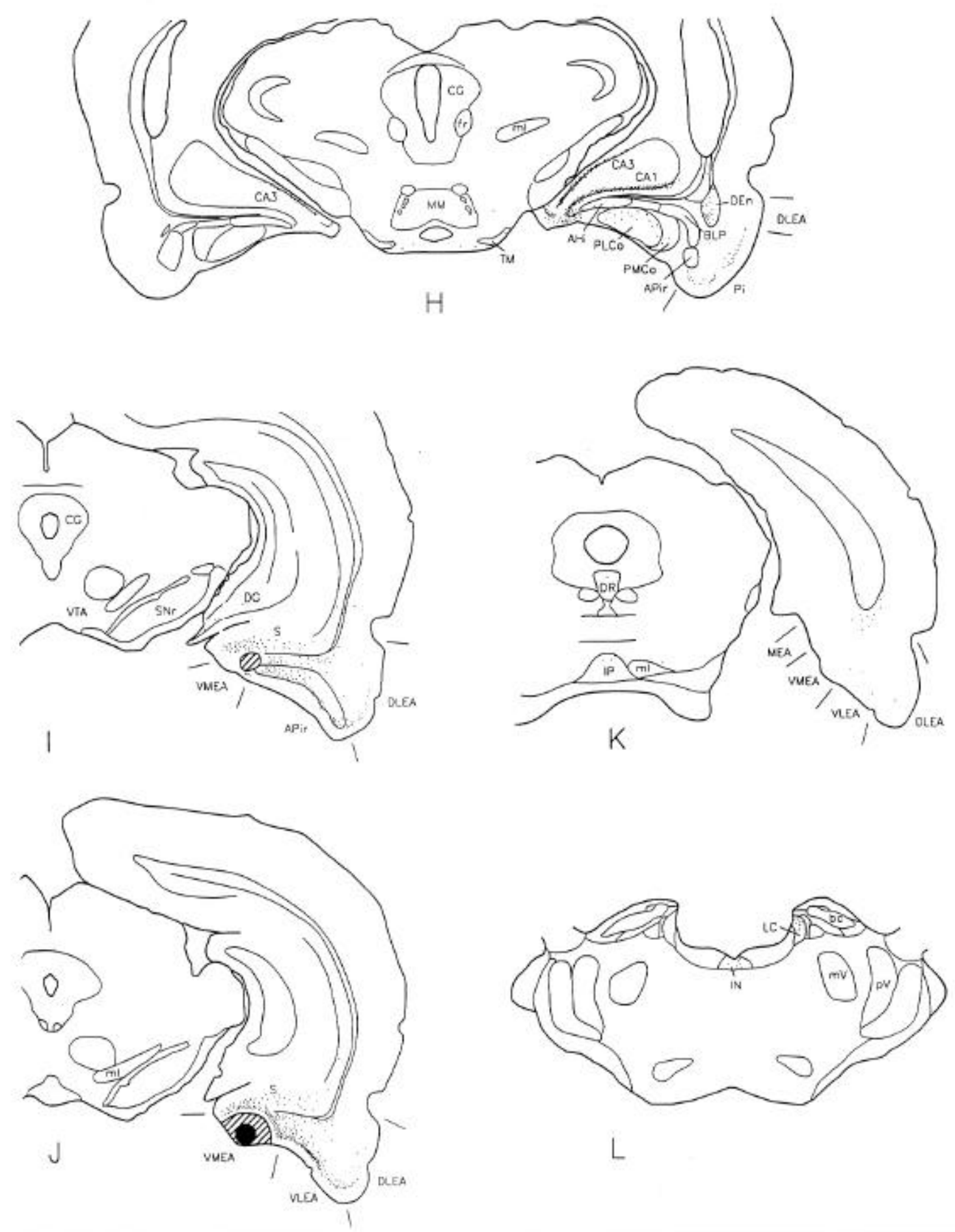

CONTINUAÇÃO DA FIGURA 11. 
APir, onde as células retrogradamente marcadas são principalmente observadas na lâmina III da sua porção medial e formam pequenos agregados celulares na lâmina II que se extendem também mais lateralmente

(Fig. 11I). Notamos uma marcação retrógrada moderada na área de transição córtico-amigdalóide (Fig. 11E), no núcleo medial, particularmente nas suas divisões ântero-ventral e póstero-ventral (Fig. 11F), e na área amígdalohipocampal (Fig. 11G-H). Um número modesto de pericários retrogradamente marcados foi observado nos núcleos corticais anterior e póstero-lateral, na área amígdalo-piriforme de Swanson (1992) e na porção medial do núcleo basomedial posterior. Escassa marcação retrógrada foi ainda encontrada na divisão ventromedial do núcleo lateral e nas divisões medial e intraamigdalóide do núcleo intersticial da estria terminal (Fig. 11E-H).

Outras estruturas telencefálicas que apresentam um número moderado de neurônios retrogradamente marcados são a porção ventral do claustrum, o núcleo septal medial e o núcleo da banda diagonal de Broca (Fig. 11C-E).

No tálamo, a porção rostral do núcleo paraventricular anterior e um território situado ventralmente ao pólo rostral do reuniens possuem densa marcação retrógrada. Notamos ainda alguns neurônios retrogradamente marcados nos núcleos paratenial e paraventricular posterior. Diferentemente dos casos com injeções nas outras subdivisões do córtex entorrinal lateral, poucas células retrogradamente marcadas foram observadas no núcleo reuniens (Fig. 11E-F).

No hipotálamo foi observada uma marcação retrógrada muito 
modesta nos núcleos ventromedial, posterior, supramamilar e tuberomamilar (Fig. 11F-H). Neste último a marcação é bilateralmente distribuída.

No tronco cerebral, o locus coeruleus e o núcleo incerto apresentam um número substancial de neurônios retrogradamente marcados (Fig. 11L). Uma marcação retrógrada modesta foi ainda observada na porção dorsomedial do núcleo interpeduncular e, em menor grau, nos núcleos dorsal e mediano da rafe (Fig. 11K).

\subsection{Tabela dos casos representativos}

Com o objetivo de facilitar a comparação entre os territórios investigados neste estudo, as fontes de aferências da APir e de cada uma das subdivisões do córtex entorrinal lateral (ventrolateral, dorsolateral e ventromedial) foram listadas na Tabela 1.

Tabela 1. Fontes de aferências à APir e às subdivisões ventrolateral (VLEA), dorsolateral (DLEA) e ventromedial (VMEA) do córtex entorrinal lateral.

A densidade relativa de marcação retrógrada é representada por símbolos:

$$
\begin{aligned}
- & =\text { ausente } & ++ & =\text { moderada } \\
+ & =\text { modesta } & +++ & =\text { densa }
\end{aligned}
$$

* Nos casos APir, a marcação retrógrada no núcleo central medial do tálamo está presente apenas na porção caudal, dorsalmente ao núcleo subparafascicular.

\begin{tabular}{|l|l|l|l|l|}
\hline & \multicolumn{1}{|c|}{ APir } & \multicolumn{1}{c|}{ VLEA } & \multicolumn{1}{c|}{ DLEA } & \multicolumn{1}{c|}{ VMEA } \\
\hline \multicolumn{1}{|c|}{ Telencéfalo } & & & & \\
\hline $\begin{array}{c}\text { Córtex } \\
\text { Cerebral }\end{array}$ & & & & \\
\hline Mi (Bulbo Olf.) & ++ & ++ & ++ & + \\
\hline PrL & - & $+(+)$ & $+(+)$ & - \\
\hline IL & - & $++(+)$ & $++(+)$ & - \\
\hline MO & - & + & + & - \\
\hline
\end{tabular}




\begin{tabular}{|c|c|c|c|c|}
\hline & APir & VLEA & DLEA & VMEA \\
\hline \multicolumn{5}{|l|}{ Telencéfalo } \\
\hline \multicolumn{5}{|l|}{$\begin{array}{c}\text { Córtex } \\
\text { Cerebral }\end{array}$} \\
\hline VO & - & + & $++(+)$ & - \\
\hline TT & + & + & + & + \\
\hline AONmd & - & + & ++ & + \\
\hline Ald & + & + & + & - \\
\hline Alv & + & ++ & ++ & - \\
\hline Alp & +++ & + & ++ & - \\
\hline $\mathrm{DI}$ & + & - & - & - \\
\hline Pi anterior & $++(++)$ & $+(+)$ & $+(+)$ & $+(+)$ \\
\hline Pi posterior & +++ & ++ & ++ & - \\
\hline DG & - & - & - & + \\
\hline CA3 (rostral) & - & - & - & $++(++)$ \\
\hline CA1 (septal) & - & + & ++ & - \\
\hline CA1 (temporal) & +++ & +++ & +++ & ++ \\
\hline $\mathrm{Sd}$ & + & - & + & - \\
\hline Sv & ++ & +++ & +++ & ++ \\
\hline Sc & ++ & +++ & +++ & - \\
\hline $\mathrm{PaS}$ & + & +++ & ++ & - \\
\hline Post & - & + & + & - \\
\hline DLEA & + & ++ & +++ & + \\
\hline VLEA & ++ & +++ & ++ & ++ \\
\hline VMEA & + & +++ & ++ & ++ \\
\hline MEA & - & + & + & + \\
\hline PRCd & - & + & ++ & - \\
\hline PRC fundus & + & ++ & +++ & - \\
\hline PRCv & + & + & ++ & - \\
\hline \multicolumn{5}{|l|}{ Amígdala } \\
\hline AA & + & + & + & - \\
\hline ACo & ++ & + & + & + \\
\hline $\mathrm{Ce}$ & + & + & + & - \\
\hline $\mathrm{Me}$ & + & ++ & + & ++ \\
\hline La & + & +++ & +++ & - \\
\hline BMA & +++ & + & + & - \\
\hline BMP & + & ++ & ++ & - \\
\hline $\mathrm{BLi}$ & - & ++ & + & - \\
\hline BLA & + & + & + & - \\
\hline BLP & +++ & + & + & - \\
\hline $\mathrm{BLV}$ & + & + & $++(++)$ & - \\
\hline PA & ++ & ++ & ++ & + \\
\hline PLCo & ++ & ++ & ++ & + \\
\hline PMCo & ++ & ++ & ++ & +++ \\
\hline APir & +++ & ++ & +++ & ++ \\
\hline $\mathrm{AHi}$ & + & + & + & + \\
\hline
\end{tabular}




\begin{tabular}{|c|c|c|c|c|}
\hline & APir & VLEA & DLEA & VMEA \\
\hline \multicolumn{5}{|c|}{$\begin{array}{c}\text { Outras } \\
\text { estruturas }\end{array}$} \\
\hline $\mathrm{Cl}$ & + & ++ & ++ & + \\
\hline DEn & +++ & +++ & +++ & ++ \\
\hline VEn & + & + & + & - \\
\hline DB & ++ & ++ & ++ & ++ \\
\hline MS & + & ++ & ++ & ++ \\
\hline BST & + & + & + & + \\
\hline MCPO & + & + & + & - \\
\hline VP & + & - & + & - \\
\hline SI & + & + & - & - \\
\hline \multicolumn{5}{|c|}{ Diencéfalo } \\
\hline \multicolumn{5}{|c|}{ Tálamo } \\
\hline PVA & + & +++ & ++ & ++ \\
\hline PVP & + & + & + & - \\
\hline PT & + & +++ & ++ & - \\
\hline $\operatorname{Re}$ & + & +++ & +++ & ++ \\
\hline $\mathrm{Rh}$ & - & + & + & - \\
\hline MD & + & + & + & - \\
\hline IMD & + & + & + & - \\
\hline CM & $++^{*}$ & + & + & - \\
\hline SPFPC & - & + & + & - \\
\hline PF & + & - & - & - \\
\hline VPPC & + & - & - & - \\
\hline PoT & + & - & - & - \\
\hline PIL & - & + & + & - \\
\hline PP & - & + & + & - \\
\hline \multicolumn{5}{|c|}{ Hipotálamo } \\
\hline VMH & + & + & + & + \\
\hline $\mathrm{PH}$ & + & + & + & + \\
\hline LH & + & + & + & + \\
\hline TM & + & + & + & + \\
\hline SuM & + & + & + & + \\
\hline PMV & - & + & + & + \\
\hline \multicolumn{5}{|c|}{$\begin{array}{l}\text { Tronco } \\
\text { Cerebral }\end{array}$} \\
\hline DR & ++ & ++ & ++ & + \\
\hline CLi & + & + & + & - \\
\hline MR & + & + & + & - \\
\hline LC & ++ & ++ & ++ & ++ \\
\hline PB & ++ & - & - & - \\
\hline VTA & + & + & + & - \\
\hline $\mathrm{RR}$ & + & + & + & - \\
\hline $\mathrm{CG}$ & + & + & + & - \\
\hline IN & - & + & + & + \\
\hline IP & - & + & + & + \\
\hline
\end{tabular}




\subsection{Controles anterógrados}

As informações obtidas com injeções de CTb e FG demonstram que o complexo basolateral constitui a grande fonte de projeção amigdaliana para a APir e para o córtex entorrinal ventrolateral. No entanto, é importante ressaltar que a APir recebe densas projeções do núcleo basolateral posterior

FIGURA 5 mas é pouco aferentado pelo núcleo lateral (Fig. 5A), enquanto que o córtex entorrinal ventrolateral é densamente aferentado pelo núcleo lateral e apenas modestamente pelo basolateral posterior (Fig. 5B). Em função das diferenças hodológicas observadas, foram realizadas injeções de PHA-L nos núcleos lateral e basolateral posterior da amígdala com o propósito de confirmar a especificidade dessas projeções.

Após injeção de PHA-L na porção caudal do núcleo basolateral

FIGURA 12 posterior (caso 134, Fig. 12) foi observado, na APir, um denso plexo terminal nas camadas profundas do seu setor medial enquanto que seu setor lateral apresentou-se apenas modestamente marcado. A camada molecular da APir possui algumas fibras varicosas que também são mais evidentes na porção medial. Este padrão de marcação, preferencialmente medial, foi observado ao longo de toda a extensão rostro-caudal da APir. No córtex entorrinal, a marcação anterógrada é muito escassa, sendo observadas algumas fibras varicosas nas camadas profundas ( $\mathrm{V}$ e $\mathrm{VI}$ ) do córtex entorrinal lateral e, em níveis mais caudais, também na lâmina II (terminologia de Krettek e Price, 1977).

Além de esclarecer a diferença quanto as projeções do núcleo 

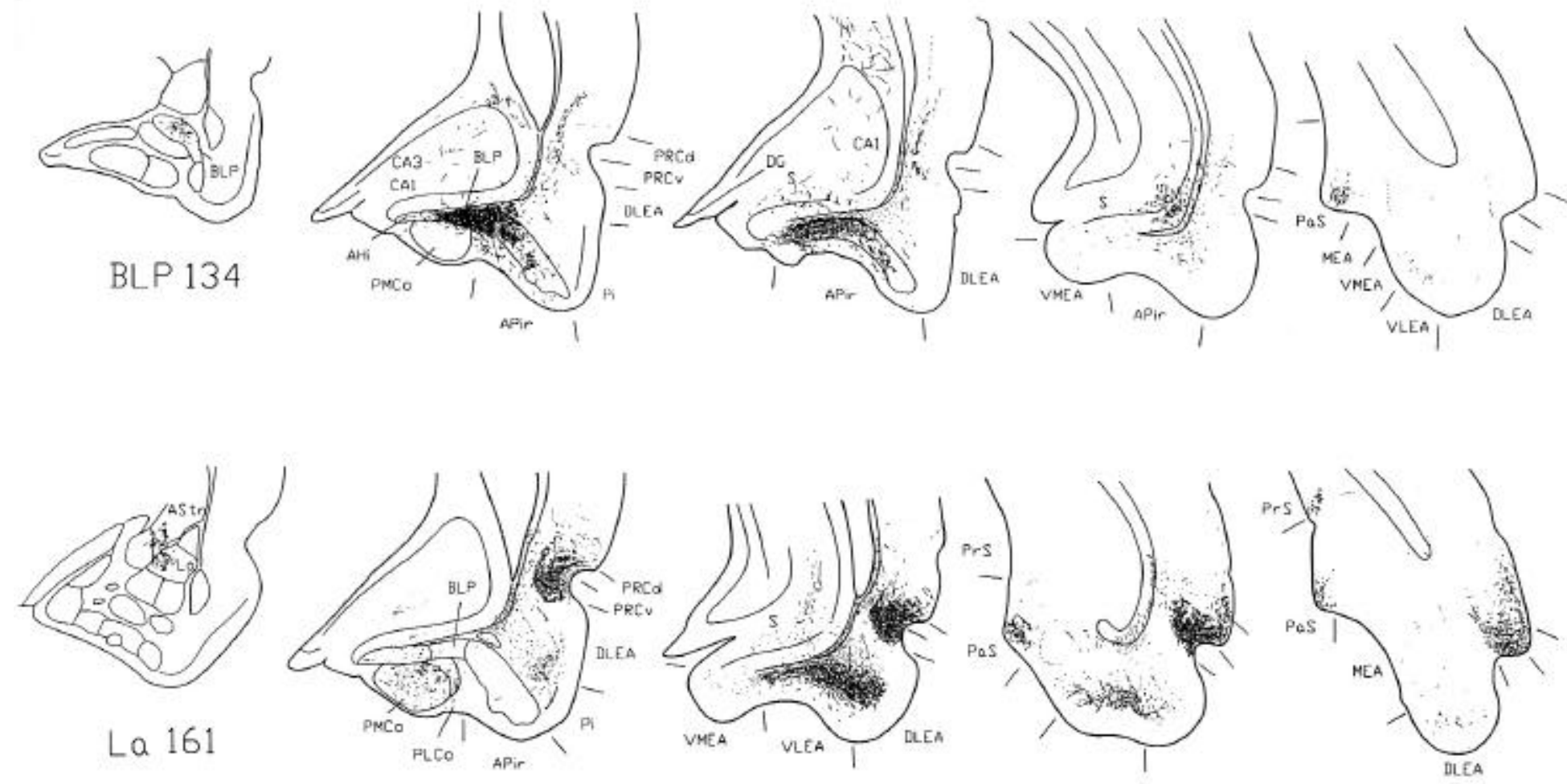

FIGURA 12. Distribuição da marcação anterógrada na APir e no córtex entorrinal após injeções de PHA-L nos núcleos amigdalóides basolateral posterior (caso 134) e lateral (caso 161). 
amigdalóide basolateral posterior para a APir e para o córtex entorrinal lateral, estes experimentos também confirmaram algumas observações extraídas dos casos com depósitos de FG confinados às porções medial e lateral da APir. Nossas observações da série experimental retrógrada indicam que a APir medial é densamente aferentada por toda a extensão rostro-caudal do núcleo basolateral posterior enquanto que a APir lateral recebe uma aferentação que se origina apenas das porções rostrais deste núcleo amigdalóide. Nossos experimentos anterógrados corroboram a evidência de que somente a APir medial recebe densas projeções dos setores caudais do núcleo basolateral posterior.

Em nenhum dos casos com injeção de PHA-L no núcleo amigdalóide FIGURA 12 lateral (caso 161, Fig. 12) foi observada marcação anterógrada na APir. No córtex entorrinal lateral, um denso plexo terminal foi observado na camada III de sua subdivisão ventrolateral enquanto que sua divisão dorsolateral exibe apenas um modesto campo terminal. A marcação no córtex entorrinal diminui caudalmente. Notamos também algumas fibras marcadas na lâmina Ilb do córtex entorrinal lateral. Assim, o número modesto de pericários retrogradamente marcados observados no núcleo amigdalóide lateral (principalmente em sua subdivisão ventromedial) em casos com injeções de CTb ou FG na APir deve ser possivelmente atribuído ao envolvimento periférico do córtex entorrinal adjacente à APir. 


\subsection{DISCUSSÃO}

\subsection{Considerações Metodológicas}

Para investigar as conexões aferentes da APir foram utilizados dois traçadores retrógrados (CTb e FG). Experimentos de rastreamento anterógrado com PHA-L foram também realizados para corroborar conclusões fundamentadas na análise da série experimental retrógrada e delinear de forma mais precisa o campo terminal de projeções amigdalofugais para a APir e o córtex entorrinal lateral adjacente. A CTb é sem dúvida um traçador de grande sensibilidade sendo que depósitos bastante restritos deste traçador são altamente eficazes para marcar retrogradamente os neurônios que aferentam um dado sítio neural (Luppi e cols., 1990). Por outro lado, este método de rastreamento sofre, em certa medida, da desvantagem de que fibras de passagem lesadas no sítio de injeção, e talvez até mesmo fibras de passagem intactas, possam captar o traçador e marcar retrogradamente células que não enviam terminações axonais para aquele dado sítio neural (Chen e Aston-Jones, 1995). Assim, aliar o uso de FG em nosso estudo mostrou-se muito interessante pois este traçador é intensamente captado pelos neurônios e, quando comparado a outros traçadores retrógrados, ele é captado em menor grau por fibras de passagem (Schmued e Fallon, 1986). Apesar de não ser o objetivo deste estudo comparar estes dois traçadores, a análise do nosso material revela que, nas condições experimentais utilizadas, o FG é mais sensível do que a CTb. Uma vantagem destes traçadores retrógrados comum também ao traçador anterógrado PHA-L é a possibilidade de serem injetados iontoforeticamente e visualizados por tratamento 
imunohistoquímico. Segundo as descrições de Gerfen e Sawchenko (1984), além de ser altamente sensível, o método do PHA-L permite a visualização dos pericários que incorporaram o traçador possibilitando uma avaliação precisa do local efetivo de captação. Este método permite também uma observação detalhada da morfologia dos axônios e arborizações terminais marcados e assim estabelecer com alto grau de certeza a presença de um campo terminal.

\subsection{Aspectos gerais das aferências da APir}

Nossos resultados sugerem que as principais fontes de aferências da APir se originam do bulbo olfativo, de áreas mesocorticais e alocorticais, incluindo os córtices insulares disgranular e agranular posterior, piriforme, entorrinal lateral e perirrinal, o campo temporal CA1 do corno de Ammon e o subiculum ventral, bem como do núcleo endopiriforme dorsal, do complexo amigdalóide, principalmente dos núcleos basomedial anterior, basolateral posterior, cortical anterior, cortical póstero-lateral e cortical póstero-medial. Várias outras estruturas, entre as quais o núcleo da banda diagonal de Broca, o pálido ventral, a substância inominada sublenticular, o pólo caudal do núcleo central medial do tálamo, o núcleo reuniens, o núcleo dorsal da rafe, o locus coeruleus e a área parabraquial representam fontes de aferências mais modestas à APir. Nossa análise sugere ainda que as aferências da APir diferem das do córtex entorrinal ventrolateral adjacente, principalmente no que diz respeito as aferências mesocorticais, do complexo amigdalóide basolateral e do tálamo da linha média. 


\subsection{Organização topográfica das aferências da APir}

Estudos anterógrados recentes mostram que a APir se projeta de forma topograficamente organizada para o núcleo amígdalóide central e para o núcleo intersticial da estria terminal (Jolkkonen e Pitkänen, 1998; Shammah-Lagnado e Santiago, 1999). Nesses estudos as diferenças topográficas foram observadas ao longo da dimensão médio-lateral da APir. Nossos experimentos retrógrados com injeções confinadas aos setores medial e lateral da APir também revelaram a existência de uma organização topográfica para algumas das conexões aferentes desta área de transição. Assim, diferenças foram observadas no que diz respeito as aferências da APir oriundas de áreas mesocorticais, do complexo amigdalóide e da formação hipocampal.

Uma característica marcante observada nos casos com depósito de FG na APir medial é a quase completa ausência de marcação retrógrada nas áreas mesocorticais. Isto contrasta com as projeções substanciais do córtex insular agranular posterior e do córtex perirrinal para os distritos laterais da APir. Esta topografia das projeções do córtex perirrinal também foi relatada por Shi e Cassell (1999) mostrando que apenas as porções laterais da APir são alvos da divisão ventral do córtex perirrinal. Nesse contexto, é interessante notar que a APir se assemelha ao córtex entorrinal pela característica de que o gradiente de inervação proveniente de áreas mesocorticais diminui das porções laterais para as porções mediais destes dois territórios (Burwell e Amaral, 1998b; Shi e Cassell, 1999; presente estudo).

$\mathrm{Na}$ amígdala, notamos que toda a extensão do núcleo basolateral posterior se projeta para o setor medial da APir enquanto que apenas as 
porções rostrais do referido núcleo amigdalóide aferentam o setor lateral da APir.

Outra observação interessante é que as aferências do campo CA1 e do subiculum para os setores medial e lateral da APir seguem o padrão das projeções recíprocas do córtex entorrinal com a formação hipocampal. Assim, de acordo com Amaral e Witter (1995), as projeções são arranjadas de forma que a dimensão médio-lateral do córtex entorrinal está representada ao longo do eixo têmporo-septal da formação hipocampal. Em nosso material notamos que a APir medial é aferentada pela porção mais ventral (temporal) do campo CA1 e pelo subiculum ventral enquanto que a APir lateral é aferentada pela porção ventral e também pela porção mais dorsal (septal) do campo CA1, e exibe uma marcação mais modesta no subiculum ventral.

\subsection{Principais aferências à APir - comparação com as informações da literatura}

Nossos resultados confirmam as observações de Beckstead (1978) no rato, e sugerem a existência de várias fontes de aferências à APir, todas elas substanciais, que não tinham sido relatadas por este autor, entre as quais as que se originam do córtex insular disgranular e agranular posterior, dos núcleos amigdalóides basolateral posterior e cortical póstero-medial, e da área parabraquial. Estas diferenças talvez se devam ao fato de Beckstead (1978) ter utilizado como traçador retrógrado a HRP, que é muito menos sensível do que os traçadores (FG e CTb) usados em nossos experimentos. Deve ser notado ainda que Beckstead explorou de forma mais sistemática o 
córtex entorrinal propriamente dito, sendo descrito apenas 1 caso com injeção na porção ântero-ventral do córtex entorrinal, região que corresponde à APir.

\subsubsection{Aferências corticais}

O bulbo olfativo projeta-se diretamente para a APir conforme observado nos casos com envolvimento da lâmina I. Este dado é consoante com a descrição de Kosel e colaboradores (1981) de projeções diretas do bulbo olfativo para o estrato mais superficial da APir. Nossas observações sugerem que as porções posteriores do córtex piriforme aferentam a APir de forma mais proeminente do que as porções anteriores e que estas projeções se originam das camadas II e III do referido córtex. A comparação entre casos com injeções que envolveram em grau variável a lâmina molecular da APir indica que a camada II do córtex piriforme anterior envia projeções, bilateralmente distribuídas, que tem por alvo preferencial a camada molecular da APir. Nossos resultados diferem das observações de Beckstead (1978) no rato. Usando a HRP como traçador retrógrado, o autor descreve que a marcação no córtex piriforme estava concentrada em sua porção rostral e se originava exclusivamente da camada II. Talvez estas discrepâncias possam em parte ser atribuídas ao fato de Beckstead ter utilizado uma penetração angulada para atingir a APir, ocorrendo uma contaminação das camadas profundas do córtex piriforme, o que explicaria a densa marcação que ele observou no córtex piriforme anterior (ver caso EC14, Fig. 1; Beckstead, 1978). Nossas observações sobre a distribuição da marcação retrógrada no córtex piriforme corroboram os resultados autoradiográficos de Luskin e Price 
(1983) sobre a organização topográfica das fibras associativas do sistema olfativo no rato. Estes autores relatam que as projeções do córtex piriforme terminam preferencialmente no estrato profundo da camada molecular (lâmina lb) e na camada III dos territórios alvos, incluindo a APir, e que apenas a porção anterior do córtex piriforme origina projeções bilateralmente distribuídas. Outras estruturas que recebem aferências olfativas oriundas do bulbo olfativo ou do córtex piriforme, entre as quais os núcleos endopiriforme dorsal e ventral, os núcleos amigdalóides cortical anterior e cortical pósterolateral também se projetam para a APir. É interessante notar que a marcação no núcleo endopiriforme também se mostrou mais acentuada nos casos em que o depósito de FG atingiu a camada molecular da APir. Este fato é consoante com estudos de rastreamento anterógrado que mostram que as porções dorsal e ventral do núcleo endopiriforme se projetam densamente para a lâmina lb da APir, enquanto que as camadas celulares da APir recebem modestas projeções do núcleo endopiriforme dorsal (Krettek e Price, 1977; Behan e Haberly, 1999). Assim, a APir é um território que faz parte do sistema olfativo e como tal está interconectado com estruturas olfativas através das fibras associativas deste sistema (Luskin e Price, 1983; Shammah-Lagnado e Santiago, 1999). É interessante notar que dentre as estruturas olfativas, apenas o núcleo endopiriforme dorsal e o núcleo basomedial anterior estão conectados à APir através de densas projeções recíprocas. Outras estruturas olfativas inervadas conspicuamente pela APir, a saber o núcleo olfativo anterior, a tenia tecta e o núcleo do trato olfativo lateral não aferentam esta área de transição de forma significativa (Shammah- 
Lagnado e Santiago, 1999; presente estudo).

Projeções do córtex insular para a APir foram descritas no rato por Saper (1982) utilizando uma técnica de rastreamento que conjuga a leucoaglutinina do germe de trigo (WGA) à HRP. No entanto, as injeções obtidas pelo autor neste estudo envolviam apenas a porção rostral do córtex insular. Nossos resultados confirmam e extendem as observações de Saper por fornecer a primeira descrição de uma projeção do córtex insular para a APir a partir de técnicas retrógradas. Assim, pudemos esclarecer que estas projeções se originam de toda a extensão da área insular agranular posterior e também, em menor grau, da área insular disgranular. A porção rostral do córtex agranular insular posterior (ao nível ântero-posterior da decussação da comissura anterior) é, dentre as áreas insulares, a que recebe as mais densas projeções da área parabraquial e que dá origem a maioria das projeções descendentes do córtex insular ao hipotálamo, à área parabraquial e ao núcleo do trato solitário (Ver Saper, 1995). A estimulação elétrica ou química desta região do córtex insular produz uma grande variedade de repostas autonômicas de acordo com um padrão topográfico definido (Ruggiero e cols., 1987 ; Yasui e cols., 1991). Desta forma a porção rostral do

FIGURA 4 córtex insular agranular posterior (Fig. 4D) representa um importante distrito visceromotor. O território viscerossensorial do córtex insular situa-se, em grande parte, dorsalmente ao distrito insular visceromotor, existindo entretando algum embricamento entre ambos. Assim, estudos eletrofisiológicos identificaram unidades responsivas a estímulos gustativos (Norgren, 1995) e interoceptivos gerais (cárdio-pulmonares e gástricos) 
localizadas, respectivamente, nas porções rostral e caudal do córtex insular disgranular. Nossos resultados indicam que as projeções do córtex insular disgranular para a APir se originam principalmente do setor caudal que corresponde a um território interoceptivo geral. Em uma série de estudos anatômicos detalhados (McDonald, 1998; Shi e Cassell, 1998b) foi mostrado FIGURA 4 que as porções caudais do córtex insular (Fig. 4E-G) estão vinculadas ao processamento de informações somestésicas. De fato, estes distritos insulares são aferentados por áreas somestésicas associativas. Como toda a extensão do córtex insular agranular posterior recebe também aferências do córtex olfativo (Luskin e Price, 1983) este distrito insular representa uma área cortical polissensorial. Assim, depreende-se do que foi exposto que informações gustativas, interoceptivas gerais e somestésicas, possivelmente já integradas a sinais olfativos, poderiam ser veiculadas à APir pelo córtex insular.

Informações polimodais altamente elaboradas também podem ser transmitidas à APir através do córtex perirrinal. Em um estudo minucioso realizado no rato com a técnica da biocitina, Shi e Cassell (1999) relataram que as porções rostrais do córtex perirrinal ventral e da região que forma 0 fundo da fissura rinal enviam densas projeções para a APir lateral. Nossas observações corroboram plenamente estes achados tanto no que diz respeito à đ̛igem como a distribuição terminal desta projeção. É interessante notar que a porção ventral do córtex perirrinal se projeta para o núcleo amigdalóide basolateral posterior e para o córtex insular agranular posterior, os quais, por sua vez, também constituem importantes fontes de aferências para a APir 
(Shi e Cassell, 1999). Estudos anatômicos sugerem ainda que as porções dorsal e ventral do córtex perirrinal integrem diferentes modalidades sensoriais. Assim, os córtices frontal, insular e piriforme inervam preferencialmente o setor ventral do córtex perirrinal, enquanto que projeções dos córtices temporal e occipital terminam de forma seletiva no setor dorsal do córtex perirrinal (ver para referências Shi e Cassell, 1999). Dessa forma, além do córtex insular, também o córtex perirrinal ventral pode veicular informações somestésicas e olfativas altamente elaboradas à APir.

Considerando as projeções da formação hipocampal para a APir, depreende-se que esta área de transição recebe não só as informações que irão adentrar o circuito intrínseco hipocampal, oriundas das camadas superficiais do córtex entorrinal, como também aquelas que já foram processadas pelo circuito e estão sendo veiculadas pelo subiculum, pelo campo CA1 de Ammon e pelas camadas profundas do córtex entorrinal (Amaral e Witter, 1995). Confirmando nossas evidências sobre a aferentação originada do subiculum, Canteras e Swanson (1992) descrevem fibras terminando na APir após injeção de PHA-L no subiculum ventral. Em investigações utilizando técnicas de rastreamento anterógrado, foram ilustradas no rato projeções do córtex entorrinal lateral para a APir (McDonald e Mascagni, 1997; Dolorfo e Amaral, 1998); cuja densidade é bastante modesta. Nossas observações indicam que o córtex entorrinal lateral, principalmente a porção rostral da subdivisão ventrolateral, aferenta a APir de um modo bastante denso. Esta discordância provavelmente se deve ao fato das injeções de PHA-L ilustradas estarem localizadas no setor caudal do 
córtex entorrinal ventrolateral (ver caso 89 de McDonald e Mascagni, 1997; e caso EC-18 de Dolorfo e Amaral, 1998).

\subsubsection{Aferências amigdalianas}

As duas principais fontes de aferências da amígdala para a APir são os núcleos basolateral posterior e basomedial anterior.

Após uma injeção extensa de HRP envolvendo as porções anterior e posterior do núcleo amigdalóide basolateral, Ottersen (1982) ilustra marcação anterógrada nas camadas profundas da APir. Nossos experimentos de controle anterógrado revelam que o núcleo basolateral posterior se projeta densamente e de forma topográfica para a APir. Tal organização topográfica está em concordância com as observações de Pikkarainen e colaboradores (1999) sobre as projeções do complexo basolateral da amígdala à formação hipocampal no rato. Os autores descrevem que toda a extensão médio-lateral da APir recebe densas projeções da porção rostro-lateral do núcleo basolateral posterior enquanto que a porção caudo-medial do referido núcleo amigdalóide se projeta preferencialmente para a APir medial. Este estudo confirma também a modesta projeção do núcleo basomedial posterior à APir originada principalmente das porções laterais deste núcleo amigdalóide.

Em nosso estudo, o núcleo basomedial anterior constitui outra grande fonte de aferência amigdaliana à APir. Segundo o relato de Petrovich e colaboradores (1996), baseado em uma investigação das conexões eferentes do núcleo basomedial anterior, este núcleo se projeta de forma densa para a lâmina Ib da APir e moderadamente para as camadas II e III. 
Os núcleos amigdalóides basolateral posterior e basomedial anterior representam alguns dos sítios amigdalianos nos quais ocorre sobreposição das informações gustativas das porções mediais do núcleo parabraquial com as informações oriundas dos córtices gustativo e visceral primário (ver revisão de McDonald, 1998). É interessante observar que as informações gustativas e viscerais podem ser transmitidas à APir não só através do processamento no complexo basolateral como também diretamente da área parabraquial e do córtex insular.

Uma projeção moderada do núcleo cortical anterior foi também descrita para a APir (Petrovich e cols., 1996) terminando preferencialmente em sua camada molecular. Isto confirma a presença de marcação retrógrada no núcleo cortical anterior em nossos experimentos e explica porque esta marcação aparece acentuada nos casos em que o depósito de traçador envolve a camada superficial da APir.

Nossas observações sugerem ainda que sinais ferormonais captados pelo orgão vomeronasal possam ser transmitidos à APir principalmente através do núcleo amigdalóide cortical póstero-medial e também de forma mais modesta pelo núcleo amigdalóide medial, os quais por sua vez recebem projeções do bulbo olfativo acessório (Scalia e Winans, 1975). Em um estudo sobre a conexões eferentes do núcleo medial da amígdala, Canteras e colaboradores (1995) decrevem projeções de todas a divisões deste núcleo para a APir sendo que as fibras marcadas terminam preferencialmente na porção medial desta área de transição. Nós identificamos ainda aferências de densidade moderada para a APir proveniente dos núcleos amigdalóides 
cortical póstero-medial e cortical póstero-lateral. Estas observações corroboram o relato de Canteras e colaboradores (1992) que descrevem projeções destes dois núcleos amigdalóides corticais para a APir.

\subsubsection{Aferências talâmicas}

As aferências talâmicas à APir são de densidade moderada. Originam-se primariamente de uma região localizada dorsalmente ao núcleo subparafascicular magnocelular, que no atlas de Swanson (1992) parece corresponder à porção mais caudal do núcleo central medial, e também do setor rostroventral do núcleo reuniens. Os núcleos paraventricular, paratenial e a porção ventromedial do núcleo parafascicular contribuem de forma mais modesta para a inervação da APir.

Cofirmando nossas observações, em um estudo no rato, Beckstead notou poucos neurônios retrogradamente marcados concentrados principalmente nas porções rostrais dos núcleos reuniens, paraventricular e paratenial em um caso com injeção de HRP na APir (ver caso EC14, Fig. 1; Beckstead, 1978). O núcleo reuniens constitui a principal fonte de aferências para o córtex entorrinal e para a formação hipocampal (Beckstead, 1978; Herkenham, 1978; Wouterlood e cols., 1990). Estas projeções são topograficamente organizadas. Assim, o setor rostroventral do núcleo reuniens - que dá origem as projeções para a APir - termina preferencialmente no córtex entorrinal e subiculum ventral, enquanto que 0 setor dorsal deste núcleo inerva o campo CA1 e o subiculum dorsal (Dolleman-Van der Weel e Witter, 1996). O significado funcional desta 
organização não foi ainda elucidado.

Em um estudo neuroanatômico empregando PHA-L e FG, Risold e Swanson (1995) sugerem que informações ferormonais processadas pela zona medial do hipotálamo possam ser veiculadas às porções rostrais do núcleo reuniens através de densas projeções dos núcleos hipotalâmicos anterior, ventromedial e pré-mamilar dorsal. Foram descritas projeções diretas do núcleo do trato solitário para territórios talâmicos intralaminares e da linha média, incluindo os núcleos paraventricular, reuniens e o setor ventromedial do núcleo parafascicular (Ricardo e Koh, 1978; Ruggiero e cols., 1998). Desse modo, informações ferormonais e viscerais podem ser transmitidas à APir através das projeções destes núcleos talâmicos.

\subsubsection{Aferências do tronco cerebral}

Plexos serotoninérgicos (Köhler e cols., 1981) e dopaminérgicos (Fallon e cols., 1978) foram identificados na APir. Nossas observações, assim como as descritas por Beckstead (1978) em um estudo de rastreamento retrógrado realizado em rato, indicam o núcleo dorsal da rafe e a área tegmental ventral/campo retrorrubral, respectivamente, como principais fontes de inervação serotoninérgica e dopaminérgica à APir. Corfirmando estas observações, Vertes (1991) também relata uma projeção oriunda da porção rostral do núcleo dorsal da rafe para a APir, com base em evidências de rastreamento anterógrado. Uma projeção do locus coeruleus para a APir fora previamente descrita por Beckstead (1978) e foi também corroborada por nós. Vemos assim que a atividade da APir é modulada por vários sistemas 
monoaminérgicos vinculados a processos motivacionais e alerta comportamental.

Aferências parabraquiais para a APir não tinham sido ainda mostradas. Nossos resultados sugerem que elas se originam principalmente dos subnúcleos medial, ventrolateral e da área da cintura. Estes territórios são inervados pela porção rostral do núcleo do trato solitário e constituem a região gustativa da área parabraquial (Fulwiler e Saper, 1984).

\subsection{Diferenças em relação aos territórios adjacentes}

O núcleo lateral é uma importante via de entrada para o processamento intra-amigdalóide pois para ele convergem diversas informações de córtices não-olfativos modalmente específicos. As informações oriundas dos bulbos olfativos principal e acessório, e do córtex olfativo primário acessam a amígdala principalmente através dos núcleos amigdalóides superficiais. A integração das informações olfativas e nãoolfativas acontece através das conexões entre o núcleo lateral e os núcleos superficiais da amígdala ou ainda através das projeções destes dois sítios para os outros núcleos do complexo amigdalóide (McDonald, 1998). É interessante notar que o núcleo lateral se projeta não só para os núcleos corticais e profundos da amigdala que limitam a APir medialmente como também para os demais territórios que circundam esta área de transição. Em vários estudos neuroanatômicos pode-se identificar as projeções do núcleo amigdalóide lateral para o núcleo basolateral posterior, para os núcleos corticais póstero-lateral e póstero-medial, para a área amígdalo-hipocampal (Pitkänen e cols., 1995), para a porção ventromedial do córtex piriforme 
posterior (caso AM-45 da figura 7 e caso AM-33 da figura 9 de Pitkänen e cols., 1995) e também para o córtex entorrinal lateral (Pikkarainen e cols., 1999), sendo que várias destas projeções são recíprocas. Nossos experimentos com injeção de PHA-L no núcleo lateral da amígdala revelam a ausência de projeções deste núcleo para a APir. Assim, é importante salientar que o núcleo amigdalóide lateral acaba funcionando como uma ferramenta diferenciadora pois exibe conexões com todos os territórios adjacentes à APir porém evita de modo marcante esta área de transição. Este fato constitui um forte argumento a favor do reconhecimento da APir como uma entidade distinta do córtex entorrinal e também dos outros núcleos da amígdala olfativa.

As conexões da APir e do córtex entorrinal lateral com o complexo amigdalóide diferem sob outro aspecto importante. Nossos experimentos anterógrados revelam que o núcleo amigdalóide basolateral posterior inerva densamente a APir e apenas modestamente o córtex entorrinal lateral enquanto que o núcleo amigdalóide lateral se projeta maciçamente para 0 córtex entorrinal lateral e evita completamente a APir (ver também Pikkarainen e cols., 1999). Dentro do complexo amigdalóide tanto o núcleo lateral como o núcleo basolateral posterior recebem projeções de áreas corticais sensoriais primárias assim como de áreas corticais associativas. No entanto, foi observado que informações visuais e auditivas, oriundas dos córtices sensoriais primários e também de áreas polimodais como o córtex perirrinal, são densamente veiculadas ao núcleo lateral enquanto que o núcleo basolateral posterior assim como o núcleo basomedial anterior 
parecem ser caracterizados por um maior envolvimento com 0 processamento de informações gustativas e viscerais recebidas diretamente dos córtices primários destas modalidades sensoriais (McDonald, 1998).

Além da APir e do córtex entorrinal ventrolateral receberem projeções praticamente complementares do complexo amigdalóide basolateral, eles também possuem aferências mesocorticais diferentes. O córtex entorrinal ventrolateral recebe projeções mesocorticais mais variadas do que a APir. Assim, os córtices orbital medial, infra-límbico e insular agranular ventral se projetam de forma substancial apenas para o córtex entorrinal ventrolateral. Toda extensão rostrocaudal do córtex insular agranular posterior inerva a APir, enquanto que as projeções deste distrito insular para o córtex entorrinal ventrolateral são bastante modestas e se originam apenas de sua porção rostral. Aferências do córtex perirrinal para a APir são oriundas principalmente da região do fundo e do lábio ventral da fissura rinal, por outro lado, o córtex entorrinal ventrolateral recebe projeções perirrinais da região do fundo e do lábio dorsal da fissura rinal (ver também Shi e Cassell, 1999). Na formação hipocampal, o parasubiculum aferenta de forma mais proeminente o córtex entorrinal ventrolateral do que a APir.

O córtex insular agranular posterior representa um importante território de convergência de informações olfativas, gustativas, viscerais gerais e somestésicas (McDonald, 1998). O setor rostral do córtex insular agranular posterior está envolvido em funções gustativas e viscerais (Kosar e cols., 1986; Yasui e cols., 1991). O setor caudal do córtex insular agranular posterior, que constitui uma importante fonte de aferência apenas à APir, 
recebe aferências de áreas corticais somestésicas associativas (McDonald, 1998). Outra diferença notável é que apenas a APir recebe aferências substanciais do córtex insular disgranular visceral. Este território corresponde à uma área visceroceptiva primária (Yasui e cols., 1991; Saper, 1995). Este dado se reveste de grande interesse visto que a APir diferencia-se do córtex entorrinal lateral por inervar de forma maciça a divisão central da amígdala expandida (Shammah-Lagnado e Santiago, 1999); esta, por sua vez, envia projeções para o hipotálamo lateral e estruturas do tronco cerebral e está relacionada com a orquestração de respostas autonômicas que acompanha a expressão de um comportamento emocional.

É interessante lembrar que o córtex perirrinal ventral integra informações somestésicas e olfativas (ver para referências Shi e Cassell, 1999).

Assim, tanto as aferências corticais (áreas insulares disgranular e agranular posterior e córtex perirrinal ventral) como as aferências do complexo amigdalóide (núcleos basomedial anterior e basolateral posterior) sugerem que a APir está envolvida mais particularmente no processamento de informações olfativas, gustativas, viscerais e somestésicas. O córtex entorrinal lateral (principalmente suas subdivisões dorsolateral e ventrolateral) por sua vez, através de projeções do córtex perirrinal dorsal (Shi e Cassell, 1999), da divisão ventromedial do núcleo amigdalóide lateral (Pitkänen e cols., 1995, 1997) e do parasubiculum (Swanson e cols., 1987), parece estar mais crucialmente relacionado com informações visuais e auditivas altamente elaboradas. 
Segundo nossos resultados, a APir difere ainda do córtex entorrinal lateral em outros aspectos que também são importantes. 1) No prosencéfalo basal foi observado que o núcleo da banda diagonal de Broca aferenta a APir, enquanto que o córtex entorrinal lateral é inervado pelo núcleo da banda diagonal de Broca e também, de forma conspícua, pelo núcleo septal medial. 2) O córtex entorrinal lateral recebe projeções talâmicas muito mais densas do que a APir. Estas se originam principalmente do núcleo reuniens, mas também dos núcleos paraventricular anterior e paratenial. Por outro lado, a principal fonte de aferência talâmica da APir se origina de um distrito talâmico da linha média que parece corresponder à porção mais caudal do núcleo central medial (Swanson, 1992) e é de densidade moderada. 3) A área parabraquial se projeta para a APir porém não contitui uma aferência ao córtex entorrinal lateral.

É interessante notar que a APir parece estar menos intimamente associado à circuitaria hipocampal do que o córtex entorrinal. Em nosso estudo sobre as conexões eferentes da APir (Shammah-Lagnado e Santiago, 1999) não foram observadas projeções para a camada molecular do giro denteado. As fibras eferentes terminavam exclusivamente no estrato lacunoso molecular do campo CA1 temporal. Além disso, o núcleo reuniens e o núcleo septal medial, que constituem duas das principais fontes de aferências subcorticais do hipocampo (Amaral e Witter, 1995) inervam apenas modestamente a APir e de forma proeminente o córtex entorrinal.

Por outro lado, a APir possui estreitas relações com o núcleo amigdalóide basolateral e a divisão central da amígdala expandida que não 
são compartilhadas pelo córtex entorrinal lateral. Nossas observações, a partir de um caso com injeção de CTb no núcleo basolateral posterior, revelam a existência de densas projeções da APir para este núcleo amigdalóide, fato que confirma observações anteriores de Ottersen (1982) no rato. Em nosso estudo com injeção de PHA-L na APir (Shammah-Lagnado e Santiago, 1999) constatamos que esta área de transição inerva macissamente a divisão central da amígdala expandida e, como muitas áreas olfativas primárias, ainda envia projeções para a divisão medial da amígdala expandida (McDonald e cols., 1999). Observamos também que a APir se projeta densamente para os núcleos basomedial anterior e basolateral posterior. Tendo-se em mente que os referidos núcleos aferentam o núcleo amigdalóide central (Ottersen, 1982; Savander e cols., 1995; Petrovich e cols., 1996), isto reforça ainda mais o estreito vínculo existente entre a APir e a circuitaria da divisão central da amígdala expandida.

\subsection{Implicações funcionais}

A convergência de informações gustativas e viscerais originadas de áreas corticais e subcorticais que ocorre em vários núcleos amigdalóides sugere que a amígdala possa ser crítica para a seleção de alimento baseado em seu sabor (McDonald, 1998). A APir é um sítio de convergência das projeções gustativas provenientes da área parabraquial (porção medial) e das projeções corticais gustativas e viscerais das áreas insulares. A convergência dessas informações ocorre também em outras estruturas da amígdala como os núcleos central, basomedial anterior, basolateral posterior e cortical 
anterior (Yasui e cols, 1991; Bernard e cols., 1993). Baseando-se nas conexões anatômicas existentes entre o núcleo basomedial anterior e os núcleos amigdalóides acima referidos (incluindo a APir), Petrovich e colaboradores (1996) sugerem um circuito específico na amígdala, composto pelas estruturas já mencionadas, particularmente relacionado com a ingesta alimentar e/ou mecanismos antecipatórios relacionados ao ato alimentar. É interessante notar que a APir possui conexões recíprocas densas com os núcleos basomedial anterior e basolateral posterior, além de receber moderada aferentação do núcleo cortical anterior e se projetar macissamente não só para o núcleo central como também para todos os outros componentes da divisão central da amígdala expandida (Shammah-Lagnado e Santiago, 1999). Desse modo a APir parece constituir um componente importante dentro do circuito proposto por Petrovich e colaboradores (1996). Essa idéia é reforçada pelas observações de Comoli (1997; comunicação pessoal) sobre a expressão da proteína fos em cérebros de ratos após comportamento predatório. Nesse estudo, os animais foram submetidos a 3 situações comportamentais (ingesta alimentar, realimentação após jejum e predação de baratas). As áreas amigdalianas ativas no grupo submetido à ingesta alimentar (animais alimentados com ração) foram o núcleo central e o cortical anterior. Nos animais que foram realimentados após jejum e nos que predaram baratas (situações em que aumenta o valor do reforço positivo do alimento), foi notada ativação mais intensa destes núcleos além do recrutamento das outras estruturas que participam do circuito proposto por Petrovich e colaboradores (1996), ou seja, os núcleos basomedial anterior, 
basolateral posterior e a APir. Este sistema recebe informações gustativas, viscerais e olfativas que podem ser altamente integradas através de conexões recíprocas. Os núcleos amigdalóides basomedial anterior e basolateral posterior estão associados com a divisão central da amígdala expandida (Alheid e cols., 1995; Shammah-Lagnado e cols., 1999). Entretanto, é relevante salientar que, dentre os componentes desse circuito, apenas o núcleo cortical anterior e a APir recebem projeções diretas do bulbo olfativo principal e, diferentemente dos outros núcleos do complexo amigdalóide, estes dois territórios exibem conexões com as divisões central e medial da amígdala expandida (Alheid e cols., 1995). Nesse contexto, os núcleos basomedial anterior, basolateral posterior e a APir, não-ativos na ingesta alimentar simples (ração), parecem ser importantes no desencadeamento do comportamento predatório e na ingesta após privação. A APir, em especial, pode ser uma estrutura decisiva pois a barata tem cheiro bastante particular, o que pode exercer um grande efeito motivacional uma vez que a APir recebe projeções diretas do bulbo olfativo e através de sua ampla influência sobre a amígdala expandida, pode promover a ativação de estruturas do hipotálamo e do tronco cerebral.

Existem evidências de que APir possa estar envolvida na regulação da saída autonômica parassimpática (Spencer e cols., 1990) e simpática (A.D. Loewy, comunicação pessoal). Em um estudo retrógrado transneuronal, Spencer e colaboradores (1990) injetaram um marcador viral no gânglio ptérigo-palatino e descreveram marcação em pericários pré-ganglionares do núcleo lacrimo-muconasal (núcleo salivatório superior), e em outros sítios 
prosencefálicos entre os quais a APir, a substância inominada e a divisão lateral do núcleo intersticial da estria terminal. Assim, através de sua participação em um sistema polissináptico que aferenta os neurônios préganglionares do núcleo lacrimo-muconasal a APir poderia influenciar a vasculatura cerebral e as funções das glândulas lacrimal, nasal e palatina. $O$ fato da APir participar de uma circuitaria que controla a atividade simpática poderia em parte explicar a mobilização desta estrutura em situações de estresse e/ou intensa ativação emocional, como por exemplo durante o comportamento predatório ou fornecimento de alimento após jejum prolongado.

Apesar de não se projetar diretamente para o giro denteado, a APir pode modular o processamento de informações dentro da formação hipocampal através de suas conexões com o córtex entorrinal lateral, o campo CA1 de Ammon e o subiculum (McDonald e Mascagni, 1997; Dolorfo e Amaral, 1998; Shammah-Lagnado e Santiago, 1999; presentes observações). Canning e Leung (1997) investigaram, em ratos anestesiados, a ativação do giro denteado e do CA1 após estimulação elétrica da APir e dos córtices entorrinal lateral e perirrinal. Corroborando nossos dados, os autores sugerem que a ativação do giro denteado após estimulação elétrica da APir não é monossináptica e seria mediada possivelmente através de uma conexão com o córtex entorrinal lateral. Este presuposto se baseia no fato da ativação do giro denteado ocorrer na camada molecular externa que corresponde ao território alvo das projeções oriundas do córtex entorrinal. Tal ativação seria resultante de uma excitação reverberante intrínseca do córtex 
entorrinal. Dentro deste contexto, os estímulos veiculados pela APir ao córtex entorrinal lateral são aí amplificados e podem exercer alguma influência sobre o processamento da formação hipocampal que é decisivo para a retenção do traço mnemônico.

Algumas informações da literatura sugerem que a APir possa estar envolvida com a gênese e propagação da atividade epiléptica. A APir expressão os genes das subunidades $\alpha 1 \mathrm{G}, \alpha 1 \mathrm{H}$ e $\alpha 1 \mathrm{l}$ da família de canais de cálcio do tipo T (Talley e cols., 1999) que pertencem ao tipo de canais de cálcio ativados por baixa voltagem (LVA), podendo ser componentes cruciais em modular a flutuação sublimiar de membrana. Dado o papel destes canais em comportamentos oscilatórios, talvez não seja surpreendente que sua disfunção esteja implicada na atividade epileptiforme e que algumas drogas antiepilépticas atuem especificamente sobre estes canais (ver para referências Talley e cols., 1999). Handforth e Ackermann (1995), utilizando um modelo de estado epiléptico eletrogênico, mapearam a progressão de crises em estruturas límbicas com o método da ${ }^{14} \mathrm{C}$-2-deoxiglucose (2DG). Através de estimulação elétrica intra-cerebral, 4 estados comportamentais progressivos (imobilidade, exploração, convulsão menor e convulsão clônica) eram induzidos. Os autores observaram que o circuito límbico ativo mais restrito, associado ao estado de imobilidade, era composto pelo núcleo intersticial da estria terminal, pelo núcleo do trato olfativo lateral, pelos núcleos amigdalóides central e basolateral posterior, pela área amígdalohipocampal e pela APir, sendo este circuito induzido após estimulação do núcleo basolateral posterior, do hipocampo caudal ou do núcleo acumbens. 
As informações do estudo de Handforth e Ackermann (1995) mostram que a APir e as estruturas a ela conectadas representam um substrato anatômico para a propagação da atividade epiléptica. Um outro estudo (Kikvadze e Foster, 1995) sugere ainda que a APir possa ser um sítio gerador de atividade epiléptica. Esta conclusão se baseia no fato de que a liberação de serotonina na APir, em vivo, está fortemente restrita à ativação dos receptores 5-HT $1 \mathrm{~B}$. A localização pré-sináptica destes receptores e a possibilidade de serem modulados por outros sistemas monoaminérgicos, além da serotonina, proporciona um mecanismo flexível através do qual a concentração de serotonina no espaço extracelular da APir, e provavelmente na fenda sináptica, possa variar de muitas ordens de magnitude mesmo na ausência de uma mudança aparente na frequência dos potenciais de ação que estão chegando. Segundo os autores, esta flexibilidade poderia levar à uma amplificação instável da neurotransmissão dentro da APir e talvez à epileptogênese. 


\subsection{CONCLUSÕES}

Tomados em conjunto, nossos dados sugerem que a APir possa desempenhar um papel na integração de informações olfativas, gustativas, interoceptivas gerais e somestésicas, e na transmissão dessas informações principalmente para a divisão central mas também para a divisão medial da amígdala expandida, para o striatum ventral e para o subiculum ventral, FIGURA 13 podendo assim modular a expressão de comportamentos motivados (ver Fig. 13).

Em resposta ao objetivo deste estudo, considerando a estreita relação da APir com a circuitaria da amígdala expandida enquanto que o córtex entorrinal está mais associado com a circuitaria hipocampal, depreendemos que estas, dentre outras diferenças hodológicas, caracterizam a APir como um território distinto do córtex entorrinal. 


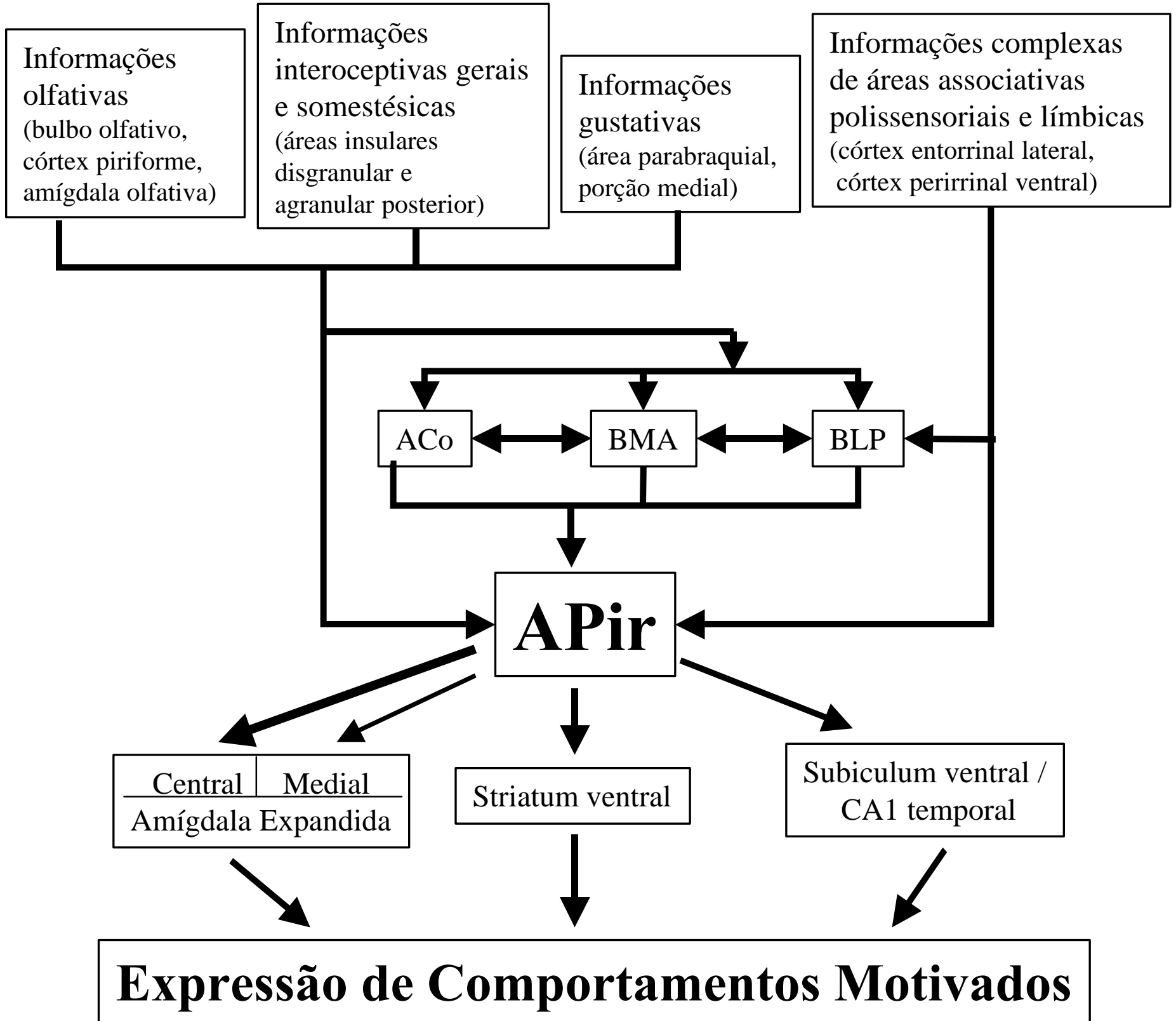

FIGURA 13. Esquema ilustrando as principais conexões da APir e os diferentes tipos de informações que poderiam ser integradas por esta área de transição e transmitidas à amígdala expandida, ao striatum ventral e à formação hipocampal, mediando assim a expressão de comportamentos motivados. 


\subsection{REFERÊNCIAS BIBLIOGRÁFICAS}

Alheid, G.F., J.S. de Olmos, and C.A. Beltramino (1995) Amygdala and extended amygdala. In: The Rat Nervous System. G. Paxinos (Ed) pp. 495-578, $2^{\text {nd }}$ ed., San Diego: Academic Press.

Amaral, D.G. and M.P. Witter (1995) Hippocampal formation. In: The Rat Nervous System. G. Paxinos (Ed) pp. 495-578, $2^{\text {nd }}$ ed., San Diego: Academic Press.

Beckstead, R.M. (1978) Afferent connections of the entorhinal area in the rat as demonstrated by retrograde cell-labeling with horseradish peroxidase. Brain Res. 152: 249-264.

Behan, M. and L.B. Haberly (1999) Intrinsic and efferent connections of the endopiriform nucleus in rat. J. Comp. Neurol. 408: 532-548.

Bernard, J.-F., M. Alden and J.-M. Besson (1993) The organization of the efferent projections from the pontine parabrachial area to the amygdaloid complex: a Phaseolus vulgaris leucoagglutinin (PHA-L) study in the rat. $J$. Comp. Neurol. 329: 201-229.

Burwell, R. D. and D.G. Amaral (1998a) Cortical afferents of the perirhinal, postrhinal and entorhinal cortices of the rat. J. Comp. Neurol. 389: 179205.

Burwell, R.D. and D.G. Amaral (1998b) Perirhinal and postrhinal cortices of the rat: interconnectivity and connections with the entorhinal cortex. J. Comp. Neurol. 391: 293-321.

Canning, K.J. and L.S. Leung (1997) Lateral entorhinal, perirhinal, and amygdala-entorhinal transition projections to hippocampal CA1 and dentate gyrus in the rat: a current source density study. Hippocampus 7 : 643-655.

Canteras, N.S. and L.W. Swanson (1992) Projections of the ventral subiculum to the amygdala, septum, and hypothalamus: a PHA-L anterograde tracttracing study in the rat. J. Comp. Neurol. 324: 180-194.

Canteras, N.S., R.B. Simerly and L.W. Swanson (1995) Organization of projections from the medial nucleus of the amygdala: a PHA-L study in the rat. J. Comp. Neurol. 360: 213-245.

Canteras, N.S., R.B. Simerly and L.W. Swanson (1992) Connections of the posterior nucleus of the amygdala. J. Comp. Neurol. 324: 143-179. 
Chen, S. and G. Aston-Jones (1995) Evidence that cholera toxin B subunit (CTb) can be avidly taken up and transported by fibers of passage. Brain Res. 674: 107-111.

Christensen, M.-K. and F.A. Geneser (1995) Distribution of neurons of origin of zinc-containing projections in the amygdala of the rat. Anat. Embryol. 191:227-237.

Comoli, E. (1997) Parte l: Estudo das conexões aferentes do núcleo prémamilar dorsal; Parte II: Caracterização da ativação do sistema nervoso central durante o comportamento predatório. São Paulo. [Dissertação de Mestrado - Instituto de Psicologia da Universidade de São Paulo].

de Olmos, J., G.F. Alheid, and C.A. Beltramino (1985) Amygdala. In: The Rat Nervous System. G. Paxinos (Ed) pp. 223-334, San Diego: Academic Press.

Dolleman-Van der Weel, M.J. and M.P. Witter (1996) Projections from the nucleus reuniens thalami to the entorhinal cortex, hippocampal field CA1, and the subiculum in the rat arise from different populations of neurons. $J$. Comp. Neurol. 364: 637-650.

Dolorfo, C.L. and D.G. Amaral (1998) Entorhinal cortex of the rat: organization of the intrinsic connections. J. Comp. Neurol. 398: 49-82.

Fallon J.H., D.A. Koziell and R.Y. Moore (1978) Catecholamine innervation of the basal forebrain. II. Amygdala, suprarhinal cortex and entorhinal cortex. J. Comp. Neurol. 180: 509-532.

Fujita M., K. Sato, M. Sato, T. Inoue, T. Kozuka and M. Tohyama (1991) Regional distribution of cells expressing glycine receptor ( subunit mRNA in the rat brain. Brain Res. 560: 23-37.

Fulwiler,C.E. and C.B. Saper (1984) Subnuclear organization of the efferent connections of the parabrachial nucleus in the rat. Brain Res. Rev. 7: 229259.

Gerfen, C.R. and P.E. Sawchenko (1984) An anterograde neuro-anatomical tracing method that shows the detailed morphology of neurons, their axons and terminals: immunohistochemical localization of an axonally transported plant lectin, Phaseolus vulgaris-leucoagglutinin. Brain Res. 290: 219-238.

Handforth, A. and R.F. Ackermann (1988) Functional [14C]2-deoxyglucose mapping of progressive states of status epilepticus induced by amygdala stimulation in rat. Brain Res. 460: 94-102. 
Handforth, A. and R.F. Ackermann (1995) Mapping of limbic seizure progressions utilizing the electrogenic status epilepticus model and the 14C-2-deoxyglucose method. Brain Res. Rev. 20: 1-23.

Haug, F.M.S. (1976) Sulphide silver pattern and cytoarchitectonics of parahippocampal areas in the rat. Special reference to the subdivision of area entorhinal (area 28) and its demarcation from the piriform cortex. Adv. Anat. Embryol. Cell Biol. 52: 1-73.

Heimer, L., R.E, Harlan, G.F. Alheid, M.M. Garcia e J. de Olmos (1997) Substantia innominata: a notion which impedes clinical-anatomical correlations in neuropsychiatric disorders. Neuroscience 76: 957-1006.

Heimer, L., G.F. Alheid, and D.S. Zahm (1993) Basal forebrain organization: an anatomical framework for motor aspects of drive and motivation. In: Limbic Motor Circuits and Neuropsychiatry. P.W. Kalivas (Ed) pp. 1-32, Boca Raton: CRC Press.

Heimer, L., J.S. de Olmos, G.F. Alheid, J. Pearson, N. Sakamoto, K. Shinoda, J. Marksteiner and R.C. Switzer (1999) The human basal forebrain. Part II. In: Handbook of Chemical Neuroanatomy. Vol. 15: The Primate Nervous System, Part III. F.E. Bloom, A. Björklund, T. Hökfelt (Eds) pp 15-164, Amsterdam, Elsevier.

Herkenham, M. (1978) The connections of the nucleus reuniens thalami: Evidence for a direct thalamo-hippocampal pathway in the rat. J. Comp. Neurol. 177: 589-609.

Insausti, R., M.T. Herrero and M.P. Witter (1997) Entorhinal cortex of the rat: cytoarchitectonic subdivisions and the origin and distribution of cortical efferents. Hippocampus 7: 146-183.

Itoh, K., A. Konishi, S. Nomura, N. Mizuno, Y. Nakamura, and T. Sugimoto (1979) Application of coupled oxidation reaction to electron microscopic demonstration of horseradish peroxidase: Cobalt-glucose oxidation method. Brain Res. 175: 341-346.

Jolkkonen, E and A. Pitkänen. (1998) Projections from the amygdalapiriform transition area to the central nucleus of the amygdala: a PHA-L study in the rat. Neurosci. Abstr., 24: 265.

Kikvadze, I. and G.A. Foster (1995) Action potential-dependent output of 5hydroxytryptamine in the anaesthetized rat amygdalopiriform cortex is strongly inhibited by tonic 5-HT1B -receptor stimulation. Brain Res. 692: 111-117.

Köhler C., V. Chan-Palay and H. Steinbusch (1981) The distribution and orientation of serotonin fibers in the entorhinal and other retrohippocampal 
areas. An immunohistochemical study with anti-serotonin antibodies in the rat's brain. Anat. Embryol. 161: 237-264.

Korzeniewska, A., S. Kasicki, M. Kaminski e K.J. Blinowska (1997) Information flow between hippocampus and related structures during various types of rat's behavior. J. Neurosc. Methods 73: 49-60.

Kosar, E., H.J. Grill and R. Norgren (1986) Gustatory cortex in the rat. I: Physiological properties and cytoarchitecture. Brain Res. 379: 329-341.

Kosel, K.C., G.W. van Hoesen, and J.R. West (1981) Olfactory bulb projections to the parahippocampal area of the rat. J. Comp. Neurol. 198: 467-482.

Krantic, S., R. Quirion and G. Uhl (1992) Somatostatin receptors. In: Handbook of Chemical Neuroanatomy. Vol. 11: Neuropeptide Receptors in the CNS. A. Björklund, T. Hökfelt and M.J. Kuhar (Eds) pp 321-346, Amsterdam, Elsevier.

Krettek, J.E., and J.L. Price (1977) Projections from the amygdaloid complex and adjacent olfactory structures to the entorhinal cortex and to the subiculum in the rat and cat. J. Comp. Neurol. 172: 723-752.

Luppi, P.O., P. Fort and M. Jouvet (1990) lontophoretic application of unconjugated cholera toxin $B$ subunit (CTb) combined with immunohistochemistry of neurochemical substances: a method for transmitter identification of retrogradly labeled neurons. Brain Res. 534: 209-224.

Luskin, M.B. and J.L. Price (1983) The topographic organization of associational fibers of the olfactory system in the rat, including centrifugal fibers to the olfactory bulb. J. Comp. Neurol. 216: 264-291.

Magistretti, P.J., J.-L. Martin, P.R. Hof and J.M. Palacios (1992) Vasoactive intestinal peptide (VIP) receptors. In: Handbook of Chemical Neuroanatomy. Vol. 11: Neuropeptide Receptors in the CNS. A. Björklund, T. Hökfelt and M.J. Kuhar (Eds) pp 347-395, Amsterdam, Elsevier.

Marksteiner, J., R. Kirchmair, S.K. Mahata, M. Mahata, R. Fischer-Colbrie, R. Hogue-Angeletti, A. Saria and H. Winkler (1993) Distribution of secretoneurin, a peptide derived from secretogranin II, in rat brain: an immunocytochemical and radioimmunological study. Neuroscience 54: 923-944.

Mascagni, F., A.J McDonald, and J.R. Coleman (1993) Corticoamygdaloid and corticocortical projections of the rat temporal cortex: A Phaseolus vulgaris leucoagglutinin study. Neuroscience 57: 697-715. 
McDonald, A.J. (1998) Cortical pathways to the mammalian amygdala. Progr. Neurobiol. 55: 257-232

McDonald, A.J. (1997) Calbindin-D28k immunoreactivity in the rat amygdala. J. Comp. Neurol. 383: 231-244.

McDonald, A.J., S.J. Shammah-Lagnado, C. Shi, A and M. Davis (1999) Cortical afferents to the extended amygdala. Ann. N.Y. Acad. Sci. 877: 309-338.

McDonald, A.J., and F. Mascagni (1997) Projections of the lateral entorhinal cortex to the amygdala: a Phaseolus vulgaris leucoagglutinin study in the rat. Neuroscience 77: 445-460.

McDonald, A.J., and F. Mascagni (1996) Cortico-cortical and corticoamygdaloid projections of the rat occipital cortex: A Phaseolus vulgaris leucoagglutinin study. Neuroscience 71: 37-54.

McDonald, A.J., F. Mascagni, and L. Guo (1996) Projections of the medial and lateral prefrontal cortices to the amygdala: A Phaseolus vulgaris leucoagglutinin study in the rat. Neuroscience 71: 55-75.

Miettinen, M., A. Pitkänen and R. Miettinen (1997) Distribution of calretininimmunoreactivity in the rat entorhinal cortex: coexistence with GABA. J. Comp. Neurol. 378: 363-378.

Norgren, R. (1995) Gustatory System. In: The Rat Nervous System. G. Paxinos (Ed) pp 751-771, $2^{\text {nd }}$ ed., San Diego: Academic Press.

Ottersen, O.P. (1982) Connections of the amygdala of the rat. IV: Corticoamygdaloid and intraamygdaloid connections as studied with axonal transport of horseradish peroxidase. J. Comp. Neurol. 205: 30-48.

Paxinos, G. and C. Watson (1986) The Rat Brain in Stereotaxic Coordinates. $2^{\text {nd }}$ Ed. San Diego: Academic Press.

Paxinos, G. and C. Watson (1997) The Rat Brain in Stereotaxic Coordinates. $3^{\text {rd }}$ Ed. San Diego: Academic Press.

Petrovich,G.D., P.Y. Risold, and L.W. Swanson (1996) Organization of projections from the basomedial nucleus of the amygdala: a PHA-L study in the rat. J. Comp. Neurol. 374:387-420, 1996

Pikkarainen, M., S. Rönkkö, V. Savander, R. Insausti and A. Pitkänen (1999) Projections from the lateral, basal, and acessory basal nuclei of the amygdala to the hippocampal formation in rat. J. Comp. Neurol. 403: 229260. 
Pitkänen, A.L., V. Savander and J.E. LeDoux (1997) Organization of intraamygdaloid circuitries in the rat: an emerging framework for understanding functions of the amygdala. Trends Neurosci. 20: (11) 517-523.

Pitkänen, A., L., Stefanacci, C.R. Farb, C.G. Go, J.E. LeDoux, and D.G. Amaral (1995) Intrinsic connections of the rat amygdaloid complex: Projections originating in the lateral nucleus. J. Comp. Neurol. 356: 288310, 1995.

Popoff, I. and N. Popoff (1929) Allocortex bei der ratte (mus decumanus). J. Psychol. Neurol. (Lpz.) 39: 257-322 and Tafel 22-33.

Price, J.L., F.T. Russchen and D.G. Amaral (1987) The limbic region. II: The amygdaloid complex. In: Handbook of Chemical Neuroanatomy. Vol. 5: Integrated Systems of the CNS, Part I. A. Björklund, T. Hökfelt and L.W. Swanson (Eds) pp 279-388, Amsterdam, Elsevier.

Quidt, M.E. and P.C. Emson (1986) Distribution of neuropeptide Y-like immunoreactivity in the rat central nervous system - II. Immunohistochemical analysis. Neuroscience 18: 545-618.

Ricardo, J.A., and E.T. Koh (1978) Anatomical evidence of direct projections from the nucleus of the solitary tract to the hypothalamus, amygdala and other forebrain structures in the rat. Brain Res. 153: 1-26.

Risold, P.Y. and L.W. Swanson (1995) Evidence for a hypothalamothalamocortical circuit mediating pheromonal influences on eye and head movements. Proc. Natl. Acad. Sci. USA 92: 3898-3902.

Romanski, L.M., and J.E. LeDoux (1993) Information cascade from primary auditory cortex to the amygdala. Corticocortical and corticoamygdaloid projections of the temporal cortex in the rat. Cereb. Cortex 3: 515-532.

Ruggiero, D.A., S. Anwar, J. Kim e S.B. Glickstein (1998) Visceral afferent pathways to the thalamus and olfactory tubercle: behavioral implications. Brain Res. 799: 159-171.

Ruggiero, D.A., S. Mraovitch,. A.R. Granata, M. Anwar, and D.J. Reis (1987) A role of the insular cortex in cardiovascular functions. J. Comp. Neurol. 257: 189-207.

Saper, C.B. (1995) Central autonomic system. In: The Rat Nervous System. G. Paxinos (Ed) pp 107-135, $2^{\text {nd }}$ ed., San Diego: Academic Press.

Saper, C.B. (1982) Convergence of autonomic and limbic connections in the insular cortex of the rat. J. Comp. Neurol. 210:163-173. 
Savander,V., C.G. Go, J.E. LeDoux, and A. Pitkänen (1995) Intrinsic connections of the rat amygdaloid complex: Projections originating in the basal nucleus. J. Comp. Neurol. 361: 345-368.

Savander,V., C.G. Go, J.E. LeDoux, and A. Pitkänen (1996) Intrinsic connections of the rat amygdaloid complex: Projections originating in the accessory basal nucleus. J. Comp. Neurol. 374:291-313.

Scalia, F. and S.S. Winans (1975) The differential projections of the olfactory bulb and accessory olfactory bulb in mammals. J. Comp. Neurol. 161: 3156.

Schmued, L.C. and J.H. Fallon, (1986) Fluoro-Gold: a new fluorescent retrograde axonal tracer with numerous unique properties. Brain Res. 377: 147-154.

Shammah-Lagnado, S.J. and A.C. Santiago (1999) Projections of the amygdalopiriform transition area (APir): A PHA-L study in the rat. Ann. N.Y. Acad. Sci. 877: 655-660.

Shammah-Lagnado, S.J., G.F. Alheid and L. Heimer (1999) Afferents connections of the interstitial nucleus of the posterior limb of the anterior commissure and adjacent amygdalostriatal transition area in the rat. Neuroscience (in press)

Shi, C.-J. and M.D. Cassell (1999) Perirhinal cortex projections to the amygdaloid complex and hippocampal formation in the rat. J. Comp. Neurol. 406: 299-328.

Shi, C.-J. and M.D. Cassell (1998a) Cortical, thalamic, and amygdaloid connections of the anterior and posterior insular cortices. J. Comp. Neurol. 399: 440-468.

Shi, C.-J. and M.D. Cassell (1998b) Cascade projections from somatosensory cortex to the rat basolateral amygdala via the parietal insular cortex. $J$. Comp. Neurol. 399: 469-491.

Skofitsch, G. and D.M. Jacobowitz (1992) Calcitonin- and calcitonin generelated peptide: receptor binding sites in the central nervous system. In: Handbook of Chemical Neuroanatomy. Vol. 11: Neuropeptide Receptors in the CNS. A. Björklund, T. Hökfelt and M.J. Kuhar (Eds) pp 97-144, Amsterdam, Elsevier.

Spencer, S.E., W.B. Sawyer, H. Wada, K.B. Platt e A.D. Loewy (1990) CNS projections to the pterygopalatine parasympathetic preganglionic neurons in the rat: a retrograde transneuronal viral cell body labeling study. Brain Res. 534: 149-169. 
Swanson L.W. and G.D. Petrovich (1998) What is the amygdala? Trends Neurosci 21: (8) 323-331.

Swanson L.W. (1992) Brain Maps: Structure of the Rat Brain. Elsevier, Amsterdam, 1992.

Swanson, L.W., C. Köhler and A. Björklund (1987) The limbic region. I: The septohippocampal system. In: Handbook of Chemical Neuroanatomy. Vol. 5: Integrated Systems of the CNS, Part I. A. Björklund, T. Hökfelt and L.W. Swanson (Eds) pp 125-277, Amsterdam, Elsevier.

Talley, E.M., L.L. Cribbs, J.-H. Lee, A. Daud, E. Perez-Reys and D.A. Bayliss (1999) Differential distribution of three members of a gene family encoding low voltage-activated (T-type) calcium channels. J. Neurosci. 19: 18951911.

Talley, E.M., D.L. Rosin, A. Lee, P.G. Guyenet and K.R. Lynch (1996) Distribution of $\alpha_{2 A}$-adrenergic receptor-like immunoreactivity in the rat central nervous system. J. Comp. Neurol. 372: 111-134.

Vertes, R.P. (1991) A PHA-L analysis of ascending projections of the dorsal raphe nucleus in the rat. J. Comp. Neurol. 313: 643-668.

Witter, M.P., and H.J. Groenewegen (1986) Connections of the parahippocampal cortex in the cat. III. Cortical and thalamic efferents. J. Comp. Neurol. 252: 1-31.

Woody, W.T., E. Wada and J. Battey (1992) Bombesin/GRP receptors. In: Handbook of Chemical Neuroanatomy. Vol. 11: Neuropeptide Receptors in the CNS. A. Björklund, T. Hökfelt and M.J. Kuhar (Eds) pp 55-95, Amsterdam, Elsevier.

Wouterlood, F.G., E. Saldana and M.P. Witter (1990) Projection from the nucleus reuniens thalami for the hippocampal region: light and electron microscopic tracing study in the rat with the anterograde tracer Phaseolus vulgaris leucoagglutinin. J. Comp. Neurol. 296: 179-203.

Yasui,Y., C.D. Breder, C.B. Saper, and D.F. Cechetto (1991) Autonomic responses and efferent pathways from the insular cortex in the rat. $J$. Comp. Neurol. 303: 355-374.

Yoshimura, R., H. Kiyama, T. Kimura, T. Araki, H. Maeno, O. Tanizawa and M. Tohyama (1993) Localization of oxytocin receptor messenger ribonucleic acid in the rat brain. Endocrinology 133: 1239-1246.

Young, W.S. and M.J. Kuhar (1981) Neurotensin receptor localization by light microscopic autoradiography in the rat brain. Brain Res. 206: 273-285. 


\section{LISTA DE ABREVIATURAS}

$\mathrm{AA}$, área amigdalóide anterior

ac, comissura anterior

Acb, núcleo acumbens

ACo, núcleo amigdalóide cortical anterior

AHi, área amígdalo-hipocampal

Ald, área insular agranular dorsal

Alp, área insular agranular posterior

Alv, área insular agranular ventral

$\mathrm{AM}$, núcleo ântero-medial do tálamo

AONmd, núcleo olfativo anterior, porção dorsomedial

AOP, núcleo olfativo anterior, porção posterior

APir, área de transição amígdalo-piriforme

APT, núcleo pré-tectal anterior

AStr, área de transição amígdalo-estriatal

BAOT, núcleo intersticial do trato olfativo acessório

bc, braço conjuntivo

BLA, núcleo amigdalóide basolateral anterior

$\mathrm{BLi}$, núcleo amigdalóide basolateral intermédio

$\mathrm{BLP}$, núcleo amigdalóide basolateral posterior

$B L V$, núcleo amigdalóide basolateral ventral

BMA, núcleo amigdalóide basomedial anterior

BMP, núcleo amigdalóide basomedial posterior

BST, núcleo intersticial da estria terminal

CA1, campo CA1 do corno de Ammon

CA3, campo CA3 do corno de Ammon

$\mathrm{Cb}$, cerebelo

$\mathrm{Ce}$, núcleo amigdalóide central

CG, substância cinzenta central

$\mathrm{Cl}$, claustrum

CLi, núcleo linear caudal da Rafe

$\mathrm{CM}$, núcleo central medial do tálamo

$\mathrm{cp}$, pedúnculo cerebral

$\mathrm{CPu}$, caudado-putâmen

CxA, área de transição córtico-amigdalóide

$\mathrm{DB}$, núcleo da banda diagonal de Broca

$\mathrm{dbc}$, decussação do braço conjuntivo

DEn, núcleo endopiriforme dorsal

$D G$, giro denteado

DI, área insular disgranular

Dlg, área insular disgranular gustativa

Dlv, área insular disgranular visceral

DLEA, córtex entorrinal lateral, subdivisão dorsolateral

DMD, núcleo dorsomedial do hipotálamo, porção dorsal 
DP, córtex peduncular dorsal

DR, núcleo dorsal da rafe

fmi, fórceps menor do corpo caloso

fr, fascículo retroflexo

fx, fórnix

GP, globo pálido

Gu, núcleo talâmico gustativo

I, massas intercaladas da amígdala

ic, cápsula interna

IC, colículo inferior

IL, córtex infra-límbico

IMD, núcleo intermédio-dorsal do tálamo

IN, núcleo incerto

IP, núcleo interpeduncular

La, núcleo amigdalóide lateral

LEA, córtex entorrinal, divisão lateral

LC, locus coeruleus

LDTg, núcleo tegmental dorso-lateral

$\mathrm{LH}$, hipotálamo lateral

LHb, núcleo habenular lateral

lo, trato olfativo lateral

LOT, núcleo do trato olfativo lateral

MCPO, núcleo pré-óptico magnocelular

$\mathrm{MD}$, núcleo médio-dorsal do tálamo

Me, núcleo amigdalóide medial

MEA, córtex entorrinal, divisão medial

$\mathrm{Mi}$, camada das células mitrais do bulbo olfativo

$\mathrm{ml}$, lemnisco medial

MM, núcleo mamilar medial

$\mathrm{MO}$, córtex orbital medial

MR, núcleo mediano da rafe

MS, núcleo septal medial

$\mathrm{mt}$, trato mamilo-talâmico

$\mathrm{mV}$, núcleo motor do trigêmeo

ot, trato óptico

OT, tubérculo olfativo

ox, quiásma óptico

PA, área amígdalo-piriforme (PAA), (Swanson, 1992)

$\mathrm{Pa}$, núcleo paraventricular do hipotálamo

$\mathrm{PaRh}$, córtex parietal-rinal

$\mathrm{PaS}$, parasubiculum

$\mathrm{PB}$, área parabraquial

el, subnúcleo externo lateral da área parabraquial

$\mathrm{m}$, subnúcleo medial da área parabraquial

vl, subnúcleo ventral lateral da área parabraquial 
PF, núcleo parafascicular do tálamo

$\mathrm{PH}$, hipotálamo posterior

$\mathrm{Pi}$, córtex piriforme

PIL, núcleo intralaminar posterior do tálamo

PLCo, núcleo amigdalóide cortical póstero-lateral

PMCo, núcleo amigdalóide cortical póstero-medial

PMV, núcleo pré-mamilar ventral

Post, pós-subiculum

PoT, núcleo posterior do tálamo

$\mathrm{PP}$, núcleo peripeduncular

PRCd, córtex perirrinal dorsal

PRC fundus, córtex perirrinal, região do fundo da fissura rinal

PRCv, córtex perirrinal ventral

PrS, pré-subiculum

$\mathrm{PT}$, núcleo paratenial do tálamo

PVA, núcleo paraventricular anterior do tálamo

$\mathrm{PVP}$, núcleo paraventricular posterior do tálamo

$\mathrm{pV}$, núcleo principal do trigêmeo

$\mathrm{R}$, núcleo reticular do tálamo

Re, núcleo reuniens do tálamo

$\mathrm{Rh}$, núcleo rombóide do tálamo

$\mathrm{RR}$, campo retrorrubral

$\mathrm{S}$, subiculum

d, porção dorsal do subiculum

$v$, porção ventral do subiculum

c, porção caudal do subiculum

SI, substância inominada

sm, estria medular

SNr, substância negra, pars reticulata

SPF, núcleo subparafascicular, porção magnocelular

SPFPC, núcleo subparafascicular, porção parvicelular

st, estria terminal

SuM, núcleo supramamilar

TM, núcleo túbero-mamilar

TT, tenia tecta

VEn, núcleo endopiriforme ventral

VLEA, córtex entorrinal lateral, subdivisão ventrolateral

VMEA, córtex entorrinal lateral, subdivisão ventromedial

$\mathrm{VMH}$, núcleo ventromedial do hipotálamo

$\mathrm{VO}$, córtex orbital ventral

VP, pálido ventral

VPPC, núcleo ventral posterior do tálamo, porção parvicelular VTA, área tegmental ventral 


\begin{abstract}
The amygdalo-piriform transition area (APir) lies at the junction of the piriform, periamygdaloid and entorhinal cortices. The afferent connections of this olfactory district were studied with retrograde tracing methods using the cholera toxin B subunit and Fluoro-Gold as tracers. Our retrograde experiments showed that the main input sources to APir derive from the olfactory bulb, mesocortical and allocortical areas including the dysgranular insular, posterior part of the agranular insular, piriform, lateral entorhinal and perirhinal cortices, temporal field CA1 of Ammon horn, ventral subiculum, as well as the endopiriform nucleus and the amygdaloid complex (anterior basomedial, posterior basolateral and anterior, posterolateral, posteromedial cortical nuclei). Several other structures among which the diagonal band, ventral pallidum, sublenticular substantia inominatta, midline thalamic nuclei, dorsal raphe nucleus, locus coeruleus and parabrachial area provide more modest inputs to APir. Our results suggest in addition that projections from mesocortical areas, hippocampal formation and the posterior basolateral amygdaloid nucleus to APir are topographically organized. Fluoro-Gold injections in the ventrolateral entorhinal cortex indicate that the afferent connections of this district differ in many regards from the afferent connections of APir. Cortical and amygdaloid inputs suggest tha APir is chiefly involved in the processing of olfactory, gustatory, visceral and somesthesic information, whereas the ventrolateral entorhinal cortex seems to be more crucially related with visual and auditory
\end{abstract}


processes. APir is also less densely projected upon by midline thalamic nuclei than the lateral entorhinal cortex.

Taken as a whole our results suggest that APir is in position to relay highly integrated olfactory, gustatory, interoceptive and somesthesic information to the extended amygdala, ventral striatum and ventral subiculum, and as such modulate the expression of motivated and emotional behavior. 